\title{
Analysis of the Literature for Carbon Kuznets Curve
}

\author{
Emrah Beșe \\ Near East University
}

H. Swint Friday

Tamus-Rellıs

\author{
Marilyn Spencer \\ Cihan Özden \\ Near East University
}

Texas A\&M University-Corpus Christi

\begin{abstract}
The aim of this study is to analyze the literature of EKC for the selected studies for the period 2002 to 2020
for income-energy-emissions nexus and provide research directions for the current literature. The result of this study shows that the general tendency in the literature is to examine the symmetric relationships between income and emissions, and the analysis of non-linear relationship between income and emissions should be increased. Although many variables are added to income-energy-emissions nexus to analyze the EKC relationship, the effect of external debt on the EKC relationships is not analyzed in the literature in detail. The effect of external debt on the EKC relationship should be analyzed for developed and developing countries. The analysis should be carried out more for developing countries than developed countries since developing countries may be financing their emission intense industries through external debt. For further research directions, this study recommends coal consumption should be analyzed instead of carbon emissions for the EKC relationship for developed and developing countries.
\end{abstract}

Keywords: environmental Kuznets curve, literature review, income, energy, emissions

\section{INTRODUCTION}

Climate change is a topic worldwide discussed by scientists, politicians and individuals. Carbon dioxide is also discussed besides climate change since it is one of the major causes for climate change and one of main greenhouse gas emissions which are carbon dioxide, methane, nitrous oxide, hydrofluorocarbons, perfluorocarbons, and sulphur hexafluoride. To cope with climate change and reduce $\mathrm{CO} 2$, many initiatives take place on individual country level and global level. For global initiatives the Paris Agreement and the Kyoto protocol can be mentioned as two of them. 
The Kyoto Protocol, as being one of the global initiatives, an international agreement which was signed and ratified with different parties on December 11, 1997, is one of the main efforts of humanity to cope with climate change and reduce $\mathrm{CO} 2$ emissions. Developing and developed countries aim to reduce their GH (Green House Gases) emissions by taking place in global initiatives. The protocol was prepared under the guidance of United Nations Framework Convention on Climate Change (UNFCC). It was first started with 37 industrialized countries and the European Union but today almost all countries involved in the protocol. Not all countries ratified Kyoto Protocol such as the United States of America (USA). The Kyoto Protocol went into practice by 2005 and by having a common objective for GH reduction, it also provides each participant country with a different commitment for emissions.

The Kyoto Protocol's first commitment period for ratified parties was between 2008 and 2012. First commitment period required involved countries to reduce their GH emissions by 5 percent below 1990 levels. Updates to protocol was made in 2011 in Morocco and in 2012 in Qatar. After 2012 meeting in Qatar, second commitment period was decided to be started between 2013 and end of 2020. New common objective was to reduce GH 18 percent below 1990 levels. Many discussions take place in the media and scientific community whether the Kyoto Protocol is successful and its contribution to the reduction level in $\mathrm{CO} 2$ and $\mathrm{GH}$ worldwide.

The Kyoto Protocol was not created just being a binding agreement by participant countries and the United Nations but it was also created to set up new initiatives to cope with GH emissions against climate change. These initiatives are carbon trading, Clean Development Mechanism and Joint Implementation. The main common point of these initiatives are the participant countries in the Kyoto Protocol can trade their excess carbon allowance on the carbon market and gain income. Also, in clean development mechanism, a participant country can make a green investment inside its borders to gain carbon credits in order to count in further commitment periods toward its emissions allowances. In joint implementation, a participant country can make a green investment in another country's territory to gain carbon credits in order to count in further commitment periods toward its emissions allowances.

The Kyoto Protocol is discussed besides the Environmental Kuznets Curve (EKC), which states income increase with $\mathrm{CO} 2$ to a certain level and after that level is reached $\mathrm{CO} 2$ starts to decrease while income increases, as well as climate change. The impact of the Kyoto Protocol on EKC is one of the determinants for countries that are involved in the protocol to determine their policy implications towards their coping strategy with climate change.

In this study, literature review for carbon Kuznets curve which involves EKC relationship, incomeemissions nexus, energy-emissions nexus, energy-income nexus, emissions-energy-income nexus with addition of variables is examined by including neutrality hypothesis, conservation hypothesis, growth hypothesis and feedback hypothesis. Each nexus is analyzed in detail and future research directions are given in conclusion part. According to neutrality hypothesis, there is no causal relationship between income and energy consumption. According to conservation hypothesis, causal relationship is directed from income to energy consumption. According to growth hypothesis, causal relationship is directed from energy consumption to income. According to feedback hypothesis, caulsa relationship is directed from income to energy consumption. The aim of this study is to analyze the literature of EKC for the selected studies for the period 2002 to 2020 and provide research directions for the current literature. 


\section{FIGURE 1}

\section{EKC CURVE}

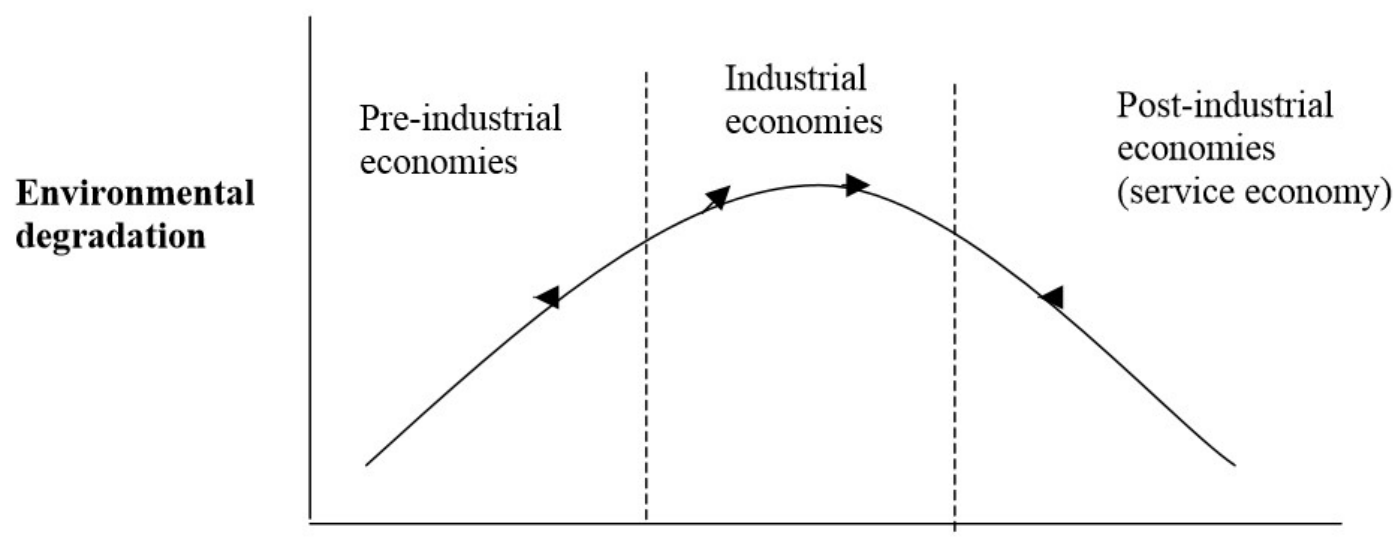

Stages of economic development

Source: Panayotuo (2003)

\section{LITERATURE REVIEW ON EKC AND ENERGY-EMISSIONS-INCOME NEXUS}

Environmental Kuznets Curve (EKC) origins started by Kuznets' (1955) article with the title of economic growth and income inequality published in the American Economic Review. Kuznets (1955) aimed to answer his main questions in his article which were whether inequality in the distribution of income decrease or increase in the course of country's economic growth and which factors determine the secular level and trends of income inequalities. He analyzed the data for United States, England and Germany which were industrialized countries. He found an inverted U-shaped relationship between income inequality and economic growth. Firstly, as economic growth increases, income inequality increases. After a certain point, as economic growth increases, income inequality declines.

In 1990s, Environmental Kuznets Curve (EKC) was examined as inverted U-shaped relationship between economic growth and environmental degradation which states at low-income levels, as income increases environmental degradation increases but after a certain point, as income increases, environmental degradation decreases. Grossman and Krueger (1991), Shafik and Bandyopadhyay (1992) and Panayotou (1993) were among the first studies for EKC hypothesis for U-shaped relationship between economic growth and environmental degradation.

Grossman and Krueger (1991) examined NAFTA's impact of environment. One of their findings was that they found that as GDP increased at the low-income level, then levels of sulfur dioxide and smoke, which are two types of environmental degradation, increased as well. After a certain point, at high-income levels, as GDP increased, levels of sulfur dioxide and smoke declined.

Shafik and Bandyopadhyay (1992) examined the relationship between economic growth and environmental quality for countries at different income levels. They used environmental indicators such as the lack of clean water, lack of urban sanitation, ambient levels of suspended particulate matter (SPM), ambient sulfur oxides (SO2), change in forest area between 1961-1986, the annual rate of deforestation, dissolved oxygen in rivers, fecal coliforms in rivers, municipal waste per capita, and carbon emissions per capita to examine the relationship between economic growth and environmental quality. For most environmental indicators not all of them, as income increased, environmental indicators worsened at lowincome levels but improved at high-income levels. Except fecal coliforms in rivers, none of the environmental got worsened in high-income levels and fecal coliforms in rivers had N-shaped relationship with income. Shafik and Bandyopadhyay (1992) concluded that there was EKC relationship between 
income and most of the environmental indicators in the study. Some exceptions to this relationship were dissolved oxygen in rivers, municipal waste and carbon emissions.

Panayotou (1993) tested and verified EKC relationship between types of environmental degradation which were deforestation and air pollution, and level of economic development for a sample of developing and developed countries. He also provided policy implications for developing and developed countries for the areas of employment, technology transfer and development assistance in his study.

Besides certain efforts to advance EKC studies as some of them stated above, explanatory variables are also used to expand EKC literature. One of the explanatory variables used in literature is trade openness variable. Trade openness variable is added to equation of CO2 and GDP in the literature to determine the effect of international trade and trade level of a country on CO2 and on GDP. Two hypotheses, which are pollution haven hypothesis and factor endowment hypothesis, are taken into consideration in the literature to provide policy implications for countries and discuss the effects of international trade and trade level of a country on emission levels and income levels.

Pollution haven hypothesis $(\mathrm{PHH})$ states that pollution policy determines the international trade between countries as trade openness increases. Pollution policies in developed countries like USA, Canada, Holland vs. can force manufacturing companies of these countries to move their industries that do not comply with certain environmental standards to developing countries like China, Vietnam, India, Mexico vs. which has low-level pollution policies and standards (Temurshoev, 2006). Comparative advantage is also determined by pollution policy. For example, under NAFTA agreement US companies can move their pollution-intensive industries to Mexico because of pollution policies in certain US states. As companies move their pollution-intensive industries to developing countries, developing countries gain comparative advantage for certain goods. As developing countries gain comparative advantage, developed countries move more pollution-intensive industries to developing countries. After a while, developing countries like China, Vietnam etc. turn into havens for multinational companies. During the process of locating industries to developing countries and after pollution-intensive industries moved to developing countries, developed countries benefit from improved environmental conditions. On the other hand, developing countries' environmental degradation worsen after pollution-intensive industries move to developing countries.

Factor endowment hypothesis (FEH) states that factor endowment, abundancy in resources and comparative advantage determine the trade between countries as openness increases (Temurshoev, 2006). According to factor endowment hypothesis, pollution policy does not determine whether the production move to another country but comparative advantage, that is determined by factor endowment of a country, does. A country which has a factor endowment to produce certain good, do not go to another country to produce it for pollution policy and also do not produce something else that it does not have a direct advantage for.

For emissions, income and energy variables, there are four research focuses in the literature which are income-emissions nexus, income-energy nexus, emissions-energy nexus and emissions-energy-income nexus.

\section{Income - Environmental Degradation Relationship}

Literature for relationship between income and environmental degradation relationship is examined under two topics which are EKC relationship and income-emissions nexus. Under EKC relationship topic, studies that indicated validity of EKC relationship are examined. Under income-emissions nexus, causality relationships and long-term and short-term relationships between emissions and income are examined.

Environmental Kuznets Curve (EKC) general model is in literature as is below:

$\ln \left(\frac{E}{P}\right)_{t}=\alpha_{0}+\alpha_{1} \ln \left(\frac{Y}{P}\right)_{t}+\alpha_{2} \ln \left(\frac{Y}{P}\right)_{t}^{2}+\alpha_{3} \ln \left(\frac{Y}{P}\right)_{t}^{3}+\alpha_{4} x_{t}+\beta t+e_{t}$

$\boldsymbol{\alpha}_{1}, \boldsymbol{\alpha}_{2,} \boldsymbol{\alpha}_{3,} \boldsymbol{\alpha}_{4}, \beta$ are estimated parameters. $\mathrm{t}$ is time index. e is error term that can be serially correlated. $\mathrm{x}$ is explanatory variable which can be energy consumption, trade openness, population etc. $\mathrm{E}$ is environmental degradation type. $\mathrm{Y}$ is economic activity type. $\mathrm{P}$ is population. 
Different level of relationships between environmental degradation and economic activity are as below (SONG, ZHENG, \& TONG, 2008).

\section{FIGURE 2}

\section{DIFFERENT LEVEL OF RELATIONSHIPS BETWEEN ENVIRONMENTAL DEGRADATION AND ECONOMIC ACTIVITY}
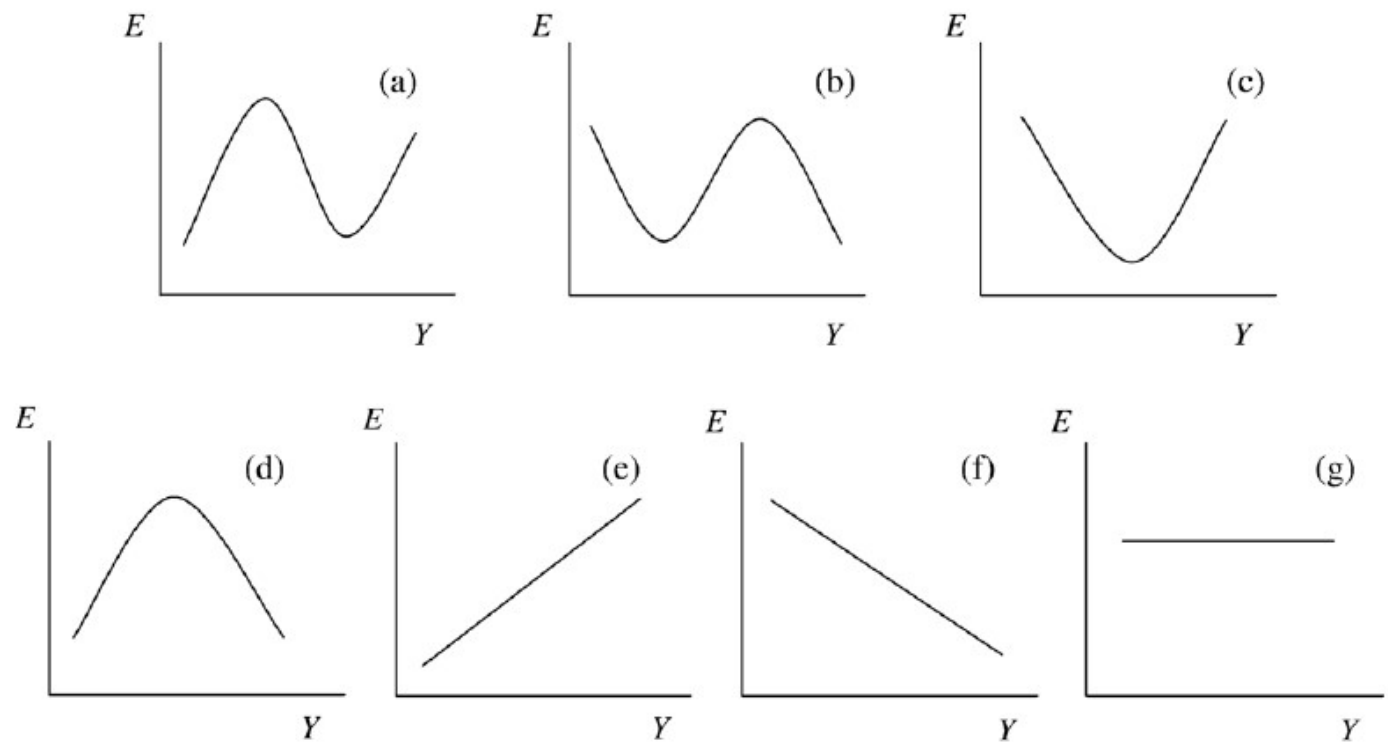

Source: Song, Zheng and Tong (2008)

a) $\boldsymbol{\alpha}_{1}>0, \boldsymbol{\alpha}_{2}<0$ and $\boldsymbol{\alpha}_{3}>0$ conclude in an N-shaped relationship between environmental degradation type (E) and economic activity (Y)

b) $\boldsymbol{\alpha}_{1}<0, \boldsymbol{\alpha}_{2}>0$ and $\boldsymbol{\alpha}_{\mathbf{3}}<0$ conclude in an inverse $\mathrm{N}$-shaped relationship between environmental degradation type (E) and economic activity (Y)

c) $\boldsymbol{\alpha}_{\mathbf{1}}<0, \boldsymbol{\alpha}_{2}>0$ and $\boldsymbol{\alpha}_{3}=0$ conclude in a U-shaped relationship between environmental degradation type (E) and economic activity (Y)

d) $\boldsymbol{\alpha}_{1}>0, \boldsymbol{\alpha}_{2}<0$ and $\boldsymbol{\alpha}_{3}=0$ conclude in EKC relationship between environmental degradation type (E) and economic activity (Y).

e) $\boldsymbol{\alpha}_{1}>0, \boldsymbol{\alpha}_{2}=0$ and $\boldsymbol{\alpha}_{3}=0$ conclude in a positive linear relationship between environmental degradation type (E) and economic activity (Y)

f) $\boldsymbol{\alpha}_{1}<0, \boldsymbol{\alpha}_{2}=0$ and $\boldsymbol{\alpha}_{3}=0$ conclude in a negative linear relationship between environmental degradation type (E) and economic activity (Y)

g) $\quad \alpha_{1}=\alpha_{2}=\alpha_{3}=0$ conclude in no relationship between environmental degradation type (E) and economic activity $(\mathrm{Y})$ 


\section{FIGURE 3 \\ IMPACTS OF INCOME ON ENVIRONMENT}

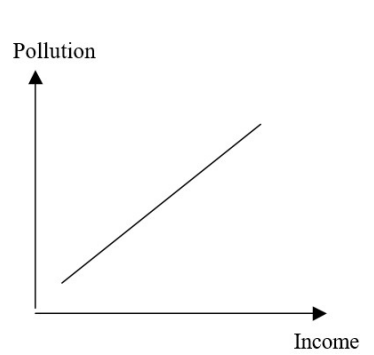

I) Level Effect

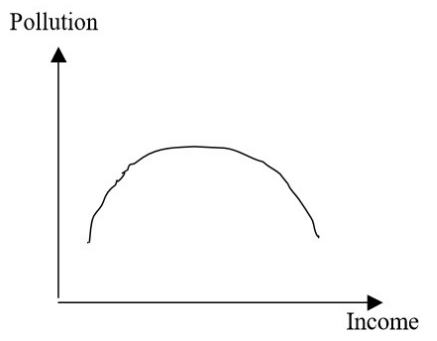

II) Composition Effect

Source: (Islam, Vincent, \& Panayotou, 1999)

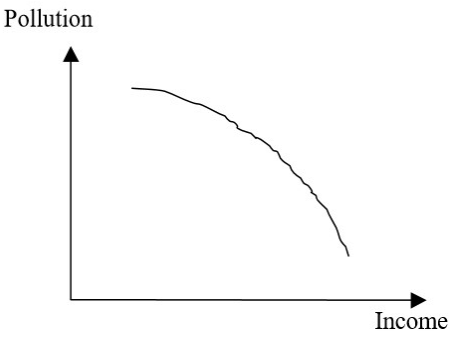

III) Abatement Effect

Different types of impacts of income on environment are examined in literature. There are three types of impacts of income on environment which are level effect, composition effect and abatement effect (Islam et al., 1999).

In level effect, higher economic activity or income, relates to higher degree of environmental degradation. There is a positive increasing linear relationship between income and environmental degradation.

In composition effect, relationship between income level and structure of economy determines the level of environmental degradation. As income level increases, it changes the structure of industry and make it more environmental friendly, more efficient and changes its output structure. As income level increases, first environmental degradation increases and after income level reaches a certain level, environmental degradation decreases. Relationship between environmental degradation and income is inverted U-shaped relationship.

In abatement effect, income level determines the demand and supply for environmental protection. As income level increases, environmental degradation level decreases. Relationship between income and environmental degradation is inverted J-shaped relationship.

\section{The EKC Relationship}

Environmental Kuznets Curve (EKC) relationship is examined in literature in many ways such as only emissions-income relationship and adding other explanatory variables such as energy consumption as well. EKC relationship is studied in literature with types of studies of panel studies, single-country and multicountry studies. EKC studies in literature are examined under two topics as the EKC relationship verified studies and the EKC relationship not verified studies.

\section{The EKC Relationship Verified}

The EKC relationship in literature is examined with CO2 and GDP variables. In some studies, explanatory variables are added to test the EKC relationship with variables such as energy consumption (ERG), renewable and non-renewable energy, primary consumption, oil consumption (OIC), economy complexity index (EI), foreign direct investment (FIDN), industrial value added (IA), financial development (FCT), trade openness (TDS), population (PLT), manufacturing export (MET), manufacturing import (MIT), investment (ITT), oil price (OIC), urbanization (UBZ) and energy intensity (ETS). Studies verified EKC relationship are outlined in Table 1,2 and 3.

For multi-country studies, Piłatowska, Włodarczyk and Zawada (2015) examined EKC relationship for 14 EU countries depending on level of knowledge. They tested EKC relationship and verified for all highlevel countries such as Denmark, Finland, Netherlands, Sweden, United Kingdom, and for some middlelevel knowledge countries such as Belgium and France. Acaravci and Ozturk (2010) examined the EKC relationship for 19 european countries and verified the EKC relationship only for Denmark and Italy among 19 european countries. Alam, Murad, Noman and Ozturk (2016) examined EKC relationship Brazil, China, 
India and Indonesia. They verified the EKC relationship for Brazil and Indonesia in both long-run and short-run and for China only in the long-run. They did not verify the EKC relationship for India. Shahbaz, Mahalik, Shah and Sato (2016) examined next 11 countries, and verified EKC relationship for Pakistan and Turkey.

For panel studies, Destek, Balli and Manga (2016) verified the EKC relationship for central and eastern european countries. Musolesi, Mazzanti and Zoboli (2010) examined the EKC relationship for 109 countries which consist of G7, OECD, EU15, non-OECD and poorest countries. They verified the EKC relationship for OECD, G7 and EU15 countries which is a quadratic relationship between CO2 and GDP. A monotonic relationship was found between CO2 and GDP for less developed countries. Arouri, Ben Youssef, M'henni and Rault (2012) verified the EKC relationship for 12 mena countries at the regionallevel but did not verify at the country-level. Linh and Lin (2015) examined 12 most populous Asian countries and tested the EKC relationship for these countries overall and only for Japan to find out whether Japan's EKC is different from overall EKC. They verified the EKC relationship for 12 most populous Asian countries and found out Japan's EKC was not different from EKC of 12 most populous Asian countries. Apergis and Ozturk (2015) verified EKC relationship for 14 asian countries.

Gao and Zhang (2014) verified the EKC relationship for 14 sub-Sahara African Countries. Kasman and Duman (2015), Osabuohien, Efobi and Gitau (2014), Kim (2015), Pao and Tsai (2011), Anastacio (2017) and Apergis and Payne (2009) verified EKC relationship for 15 countries which Bulgaria, Croatia, Czech Republic, Estonia, Hungary, Iceland, Latvia, Lithuania, FYR of Macedonia, Malta, Poland, Romania, Slovak Republic, Slovenia, and Turkey, 50 African Countries, Asian Newly Industrialized Countries, Brazil, Russia, India and China, Canada, United States, Mexico and six central American countries respectively.

TABLE 1

STUDIES VERIFY THE EKC RELATIONSHIP - MULTI COUNTRY

\begin{tabular}{|c|c|c|c|c|c|}
\hline Author(s) & Sample & Period & Methodology & Variables & Results \\
\hline $\begin{array}{c}\text { Pilatowska, } \\
\text { Wlodarczyk } \\
\text { and Zawada } \\
\text { (2015) }\end{array}$ & $\begin{array}{l}14 \text { EU Countries } \\
\text { Except Germany }\end{array}$ & $\begin{array}{l}1960- \\
2010\end{array}$ & $\begin{array}{c}\text { Threshold } \\
\text { Autoregressive } \\
\text { (TAR) Model \& } \\
\text { Momentum } \\
\text { Threshold } \\
\text { Autoregressive } \\
\text { (MTAR) Model } \\
\text { \& Non-Linear } \\
\text { Threshold } \\
\text { Cointegration } \\
\text { (NTAR) }\end{array}$ & $\begin{array}{c}\text { CO2, GDP, } \\
\text { ERG }\end{array}$ & $\begin{array}{l}\text { 1. The EKC } \\
\text { hypothesis is valid } \\
\text { for all high-level and } \\
\text { some middle-level } \\
\text { knowledge advanced } \\
\text { economies (Belgium } \\
\text { and France). }\end{array}$ \\
\hline $\begin{array}{l}\text { Acaravci and } \\
\text { Ozturk } \\
\text { (2010) }\end{array}$ & $\begin{array}{l}19 \text { European } \\
\text { Countries }\end{array}$ & $\begin{array}{l}1960- \\
2005\end{array}$ & $\begin{array}{c}\text { Autoregressive } \\
\text { Distributed Lag } \\
\text { (ARDL) Bounds } \\
\text { Testing } \\
\text { Approach of } \\
\text { Cointegration, } \\
\text { Error- } \\
\text { Correction } \\
\text { Based Granger } \\
\text { Causality Model } \\
\text { (ECGC) }\end{array}$ & $\begin{array}{c}\text { CO2, GDP, } \\
\text { ERG }\end{array}$ & $\begin{array}{l}\text { 1. The EKC } \\
\text { Relationship is } \\
\text { verified for } \\
\text { Denmark and Italy. }\end{array}$ \\
\hline
\end{tabular}




\begin{tabular}{|c|c|c|c|c|c|}
\hline $\begin{array}{l}\text { Alam, } \\
\text { Murad, } \\
\text { Noman and } \\
\text { Ozturk } \\
(\mathbf{2 0 1 6 )}\end{array}$ & $\begin{array}{l}\text { Brazil, China, India } \\
\text { and Indonesia }\end{array}$ & $\begin{array}{c}1970- \\
2012\end{array}$ & $\begin{array}{l}\text { Autoregressive } \\
\text { Distributed Lag } \\
\text { (ARDL) bounds } \\
\text { test, VECM } \\
\text { (Vector Error } \\
\text { Correction } \\
\text { Model), } \\
\text { Gregory- } \\
\text { Hansen } \\
\text { cointegration } \\
\text { approach (GH) }\end{array}$ & $\begin{array}{l}\text { CO2, GDP, } \\
\text { ERG, PLT }\end{array}$ & $\begin{array}{l}\text { 1. EKC is verified } \\
\text { for Brazil and } \\
\text { Indonesia in both } \\
\text { long and short run. } \\
2 \text {. EKC is verified } \\
\text { for China only in } \\
\text { long-run. } \\
\text { 3. EKC is not } \\
\text { verified for India. }\end{array}$ \\
\hline $\begin{array}{c}\text { Shahbaz, } \\
\text { Mahalik, } \\
\text { Shah and } \\
\text { Sato (2016) } \\
\end{array}$ & Next 11 Countries & $\begin{array}{c}1972- \\
2013\end{array}$ & $\begin{array}{c}\text { Time-varying } \\
\text { Granger } \\
\text { Causality (GC) }\end{array}$ & $\begin{array}{l}\text { CO2, GDP, } \\
\text { ERG }\end{array}$ & $\begin{array}{l}\text { 1. The EKC } \\
\text { relationship is } \\
\text { verified for Pakistan } \\
\text { and Turkey. }\end{array}$ \\
\hline
\end{tabular}

TABLE 2

STUDIES VERIFY THE EKC RELATIONSHIP - PANEL STUDIES

\begin{tabular}{|c|c|c|c|c|c|}
\hline Author(s) & Sample & Period & Methodology & Variables & Results \\
\hline $\begin{array}{l}\text { Destek, } \\
\text { Balli and } \\
\text { Manga } \\
(2016)\end{array}$ & $\begin{array}{l}\text { Central and } \\
\text { Eastern } \\
\text { European } \\
\text { Countries }\end{array}$ & $\begin{array}{c}1991- \\
2011\end{array}$ & $\begin{array}{c}\text { FMOLS } \\
\text { (Fully } \\
\text { Modified } \\
\text { Ordinary } \\
\text { Least } \\
\text { Squares), } \\
\text { DOLS } \\
\text { (Dynamic } \\
\text { Ordinary } \\
\text { Least } \\
\text { Squares), } \\
\text { Panel VECM } \\
\text { Granger } \\
\text { Causality } \\
\text { Method }\end{array}$ & $\begin{array}{l}\text { CO2, GDP, } \\
\text { ERG, UBZ, } \\
\text { TDS }\end{array}$ & $\begin{array}{l}\text { 1. The environmental Kuznets } \\
\text { curve (EKC) hypothesis holds for } \\
\text { these countries. The EKC } \\
\text { Relationship is verified. }\end{array}$ \\
\hline $\begin{array}{l}\text { Musolesi, } \\
\text { Mazzanti } \\
\text { and Zoboli } \\
(\mathbf{2 0 1 0})\end{array}$ & $\begin{array}{c}109 \\
\text { Countries }\end{array}$ & $\begin{array}{c}1959- \\
2001\end{array}$ & $\begin{array}{c}\text { Hierarchical } \\
\text { Bayes } \\
\text { Estimator }\end{array}$ & $\mathrm{CO} 2, \mathrm{GDP}$ & $\begin{array}{l}\text { 1. Supports the EKC hypothesis } \\
\text { for OECD, G7 and EU15 groups } \\
\text { but does not support the EKC } \\
\text { hypothesis for less-developed } \\
\text { countries. } \\
\text { 2. The EU shows a clear EKC } \\
\text { shape. } \\
\text { 3. Provides Evidence of an EKC } \\
\text { relationship between CO2 and } \\
\text { GDP, is limited to the OECD, G7 } \\
\text { and EU15 groups. } \\
\text { 4. A monotonic relationship } \\
\text { between income and emissions for } \\
\text { less-developed countries. } \\
\text { Industrialized countries verify } \\
\text { EKC in quadratic specifications. }\end{array}$ \\
\hline
\end{tabular}




\begin{tabular}{|c|c|c|c|c|c|}
\hline $\begin{array}{c}\text { Arouri, } \\
\text { Ben } \\
\text { Youssef, } \\
\text { M'henni } \\
\text { and Rault } \\
\text { (2012) } \\
\end{array}$ & $\begin{array}{l}12 \text { MENA } \\
\text { countries }\end{array}$ & $\begin{array}{l}1981- \\
2005\end{array}$ & $\begin{array}{c}\text { Panel } \\
\text { cointegration } \\
\text { test and } \\
\text { Panel error } \\
\text { correction } \\
\text { model }(\mathrm{ECM}) \\
\end{array}$ & $\begin{array}{l}\text { CO2, GDP, } \\
\text { ERG }\end{array}$ & $\begin{array}{l}\text { 1. The EKC Relationship is } \\
\text { verified at the regional-level but } \\
\text { not verified at the country-level. }\end{array}$ \\
\hline $\begin{array}{l}\text { Linh and } \\
\text { Lin }(2015)\end{array}$ & $\begin{array}{l}12 \text { most } \\
\text { populous } \\
\text { Asian } \\
\text { countries }\end{array}$ & $\begin{array}{c}1980- \\
2010\end{array}$ & $\begin{array}{c}\text { Johansen } \\
\text { Cointegration } \\
\text { Test (JCT), } \\
\text { Panel } \\
\text { Granger } \\
\text { Causality } \\
\text { Test, VECM, } \\
\text { OLS } \\
\text { (Ordinary } \\
\text { Least } \\
\text { Squares) } \\
\end{array}$ & $\begin{array}{l}\text { CO2, GDP, } \\
\text { ERG, FIDN }\end{array}$ & $\begin{array}{l}\text { 1. Supports the Environmental } \\
\text { Kuznets Curve (EKC). Japan's } \\
\text { EKC is not different from } 12 \text { most } \\
\text { populous Asian countries }\end{array}$ \\
\hline $\begin{array}{l}\text { Apergis } \\
\text { and Ozturk } \\
\quad(2015)\end{array}$ & $\begin{array}{l}14 \text { Asian } \\
\text { Countries }\end{array}$ & $\begin{array}{c}1990- \\
2011\end{array}$ & $\begin{array}{c}\text { Panel Co- } \\
\text { integration } \\
\text { Tests, Panel } \\
\text { GMM } \\
\text { (Generalized } \\
\text { Method of } \\
\text { Moments) } \\
\text { Methodology }\end{array}$ & $\begin{array}{c}\text { CO2, GDP, } \\
\text { PLT, IA, ISQ } \\
\text { (Political } \\
\text { Stability, } \\
\text { Government } \\
\text { Effectiveness, } \\
\text { Quality of } \\
\text { regulation, } \\
\text { Control of } \\
\text { corruption) }\end{array}$ & $\begin{array}{l}\text { 1. The EKC Relationship is } \\
\text { verified for panel countries. }\end{array}$ \\
\hline
\end{tabular}

Mallick and Tandi (2015) tested the EKC relationship for Selected SAARC countries Bangaldesh, India, Nepal, Pakistan, and Sri Lanka. The EKC relationship was not verified for panel countries in the long run, but EKC relationship was verified for Bangladesh and Sri Lanka in individual analysis.

TABLE 2 CONTINUED

\begin{tabular}{|c|c|c|c|c|c|}
\hline Author(s) & Sample & Period & Methodology & Variables & Results \\
\hline $\begin{array}{c}\text { Gao and } \\
\text { Zhang (2014) }\end{array}$ & $\begin{array}{c}14 \text { sub-Sahara } \\
\text { African } \\
\text { Countries }\end{array}$ & $\begin{array}{c}1980- \\
2009\end{array}$ & $\begin{array}{c}\text { Pedroni Panel } \\
\text { Cointegration } \\
\text { and Panel } \\
\text { vector error } \\
\text { correction } \\
\text { modelling } \\
\text { methods, } \\
\text { FMOLS \& } \\
\text { DOLS, Panel } \\
\text { Engel-Granger } \\
\text { Causality Test }\end{array}$ & $\begin{array}{c}\text { CO2, GDP, } \\
\text { ERG }\end{array}$ & $\begin{array}{l}\text { 1. The inverted U- } \\
\text { shaped Environmental } \\
\text { Kuznets Curve (EKC) } \\
\text { hypothesis exists in the } \\
\text { SSA countries' case. }\end{array}$ \\
\hline
\end{tabular}




\begin{tabular}{|c|c|c|c|c|c|}
\hline $\begin{array}{l}\text { Kasman and } \\
\text { Duman } \\
\text { (2014) }\end{array}$ & $\begin{array}{c}15 \text { countries } \\
\text { (Bulgaria, } \\
\text { Croatia, Czech } \\
\text { Republic, } \\
\text { Estonia, } \\
\text { Hungary, } \\
\text { Iceland, Latvia, } \\
\text { Lithuania, FYR } \\
\text { of Macedonia, } \\
\text { Malta, Poland, } \\
\text { Romania, Slovak } \\
\text { Republic, } \\
\text { Slovenia, and } \\
\text { Turkey) } \\
\end{array}$ & $\begin{array}{c}1992- \\
2010\end{array}$ & $\begin{array}{l}\text { Panel Data } \\
\text { Analysis }\end{array}$ & $\begin{array}{l}\text { CO2, GDP, } \\
\text { ERG, TDS, } \\
\text { UBZ }\end{array}$ & $\begin{array}{l}\text { 1. The EKC } \\
\text { Relationship is } \\
\text { verified } \\
\text { - an inverted } U \text { - } \\
\text { shaped relationship } \\
\text { between environment } \\
\text { and income for the } \\
\text { sampled countries }\end{array}$ \\
\hline $\begin{array}{l}\text { Osabuohien, } \\
\text { Efobi and } \\
\text { Gitau (2014) }\end{array}$ & $\begin{array}{l}50 \text { African } \\
\text { Countries }\end{array}$ & $\begin{array}{c}1995- \\
2010\end{array}$ & $\begin{array}{c}\text { Panel } \\
\text { Cointegration } \\
\text { Approach, } \\
\text { Vector } \\
\text { Autoregressive } \\
\text { Technique \& } \\
\text { PDOLS }\end{array}$ & $\begin{array}{c}\text { CO2, GDP, } \\
\text { GDP2, ISQ } \\
\text { (Rule of Law, } \\
\text { Regulatory } \\
\text { Quality, } \\
\text { Government } \\
\text { Effectiveness), } \\
\text { TDS } \\
\end{array}$ & $\begin{array}{l}\text { 1. The EKC } \\
\text { Relationship is } \\
\text { verified in Africa. }\end{array}$ \\
\hline Kim (2015) & $\begin{array}{c}\text { Asian Newly } \\
\text { Industrialized } \\
\text { Countries } \\
\end{array}$ & $\begin{array}{c}1971- \\
2011\end{array}$ & $\begin{array}{c}\text { VECM \& Panel } \\
\text { Granger } \\
\text { Causality Test } \\
\end{array}$ & $\begin{array}{l}\text { CO2, GDP, } \\
\text { ERG, FIDN }\end{array}$ & $\begin{array}{l}\text { 1. The EKC } \\
\text { Relationship is } \\
\text { verified. }\end{array}$ \\
\hline $\begin{array}{l}\text { Pao and Tsai } \\
\text { (2011) }\end{array}$ & $\begin{array}{l}\text { Brazil, Russia, } \\
\text { India and China }\end{array}$ & $\begin{array}{c}1980- \\
2007 \\
\text { (Russia } \\
-1992- \\
2007)\end{array}$ & $\begin{array}{c}\text { Panel } \\
\text { Cointegration } \\
\text { Framework \& } \\
\text { Panel Causality } \\
\text { Test }\end{array}$ & $\begin{array}{l}\text { CO2, GDP, } \\
\text { ERG, FIDN }\end{array}$ & $\begin{array}{l}\text { 1. The EKC } \\
\text { Relationship is } \\
\text { verified. Supportive of } \\
\text { the EKC hypothesis, } \\
\text { with emissions } \\
\text { increasing with } \\
\text { real output, } \\
\text { stabilizing, and then } \\
\text { declining. }\end{array}$ \\
\hline $\begin{array}{c}\text { Anastacio } \\
\text { (2017) }\end{array}$ & $\begin{array}{l}\text { Canada, United } \\
\text { States, Mexico }\end{array}$ & $\begin{array}{l}1980- \\
2008\end{array}$ & $\begin{array}{c}\text { Panel Pedroni } \\
\text { Cointegration } \\
\text { Tests, Panel } \\
\text { Granger } \\
\text { Causality } \\
\text { Analysis, } \\
\text { VECM Model }\end{array}$ & $\begin{array}{l}\text { CO2, GDP, } \\
\text { FIDN }\end{array}$ & $\begin{array}{l}\text { 1. The EKC } \\
\text { Relationship is } \\
\text { verified for North } \\
\text { America countries } \\
\text { (Canada, United } \\
\text { States and Mexico). }\end{array}$ \\
\hline $\begin{array}{l}\text { Mallick and } \\
\text { Tandi (2015) }\end{array}$ & $\begin{array}{c}\text { Selected SAARC } \\
\text { countries } \\
\text { (Bangaldesh, } \\
\text { India, Nepal, } \\
\text { Pakistan, and Sri } \\
\text { Lanka }\end{array}$ & $\begin{array}{c}1972- \\
2010\end{array}$ & $\begin{array}{c}\text { Panel } \\
\text { Cointegration } \\
\text { Test \& Fully } \\
\text { Modified Least } \\
\text { Square }\end{array}$ & $\begin{array}{l}\text { CO2, GDP, } \\
\text { ERG, TDS }\end{array}$ & $\begin{array}{l}\text { 1. The EKC } \\
\text { Relationship is not } \\
\text { verified for Selected } \\
\text { SAARC countries in } \\
\text { the long-run. } \\
\text { 2. In individual } \\
\text { analysis, the EKC } \\
\text { Relationship is } \\
\text { verified for } \\
\text { Bangladesh and Sri } \\
\text { Lanka. }\end{array}$ \\
\hline
\end{tabular}




\begin{tabular}{|l|c|c|c|c|c|}
\hline & Apergis and & $\begin{array}{c}\text { Panel } \\
\text { Payne (2009) }\end{array}$ & $\begin{array}{c}\text { American } \\
\text { Countries } \\
\text { Contegration } \\
\text { test, Panel } \\
\text { error } \\
\text { correction } \\
\text { model, FMOLS }\end{array}$ & $\begin{array}{c}\text { CO2, GDP, } \\
\text { ERG }\end{array}$ & 1. EKC is verified. \\
\hline
\end{tabular}

TABLE 3

STUDIES VERIFY THE EKC RELATIONSHIP - SINGLE-COUNTRY STUDIES

\begin{tabular}{|c|c|c|c|c|c|}
\hline Author(s) & Sample & Period & Methodology & Variables & Results \\
\hline Amri (2017) & Algeria & $\begin{array}{c}1980- \\
2011\end{array}$ & $\begin{array}{l}\text { ARDL with Break } \\
\text { Point Model }\end{array}$ & $\begin{array}{l}\text { CO2, GDP, ERG } \\
\text { (Non-renewable } \\
\text { \& Renewable) }\end{array}$ & $\begin{array}{l}\text { 1. The EKC } \\
\text { Relationship is verified } \\
\text { but estimated GDP } \\
\text { turning point is not } \\
\text { within examined } \\
\text { period. }\end{array}$ \\
\hline $\begin{array}{l}\text { Latifa, Yang } \\
\text { and } \mathrm{Xu} \\
(2014)\end{array}$ & Algeria & $\begin{array}{c}1965- \\
2009\end{array}$ & $\begin{array}{c}\text { ARDL \& Granger } \\
\text { Causality Test \& } \\
\text { VECM }\end{array}$ & $\mathrm{CO} 2, \mathrm{GDP}$ & $\begin{array}{l}\text { 1. The EKC } \\
\text { Relationship is verified } \\
\text { both in short-term and } \\
\text { long-term. }\end{array}$ \\
\hline $\begin{array}{l}\text { Tanga and } \\
\text { Tan }(2016)\end{array}$ & Cambodia & $\begin{array}{c}1980- \\
2010\end{array}$ & $\begin{array}{l}\text { Toda and Yamamoto } \\
\text { testing method, } \\
\text { Granger non- } \\
\text { causality test and } \\
\text { ARDL }\end{array}$ & $\begin{array}{l}\text { CO2, GDP, ERG } \\
\text { (Primary } \\
\text { Consumption, } \\
\text { Oil } \\
\text { Consumption) }\end{array}$ & $\begin{array}{l}\text { 1. The EKC } \\
\text { Relationship is verified. }\end{array}$ \\
\hline $\begin{array}{l}\text { Jalil and } \\
\text { Mahmud } \\
\text { (2009) }\end{array}$ & China & $\begin{array}{l}1975- \\
2005\end{array}$ & ARDL & $\begin{array}{l}\text { CO2, GDP, } \\
\text { ERG, TDS }\end{array}$ & $\begin{array}{l}\text { 1. EKC is verified. } \\
\text { Quadratic relationship } \\
\text { between income and } \\
\text { CO2 emission for the } \\
\text { sample period. }\end{array}$ \\
\hline $\begin{array}{l}\text { Can \& } \\
\text { Gozgor } \\
(\mathbf{2 0 1 6})\end{array}$ & France & $\begin{array}{c}1964- \\
2011\end{array}$ & $\begin{array}{c}\text { Cointegration Test } \\
\text { of Maki, DOLS, } \\
\text { ECM (Error } \\
\text { Correction Model), } \\
\text { Granger Causality } \\
\text { Test \& Block } \\
\text { Exogeneity Wald } \\
\text { Test }\end{array}$ & $\begin{array}{l}\text { CO2, GDP, } \\
\text { ERG, Economy } \\
\text { Complexity } \\
\text { Index (EI) }\end{array}$ & $\begin{array}{l}\text { 1. The EKC } \\
\text { Relationship is verified } \\
\text { in France both in short- } \\
\text { run and long-run. } \\
\text { (There is an inverted U } \\
\text { relationship between } \\
\text { income and CO2 } \\
\text { emissions in France.) } \\
\text { 3. A higher economic } \\
\text { complexity suppresses } \\
\text { CO2 emissions in the } \\
\text { long run. (relationship) }\end{array}$ \\
\hline $\begin{array}{l}\text { Yazdi and } \\
\text { Mastorakis } \\
(2016) \\
\end{array}$ & Iran & $\begin{array}{c}1975- \\
2011\end{array}$ & $\begin{array}{l}\text { ARDL \& Granger } \\
\text { Causality Analyses }\end{array}$ & $\begin{array}{l}\text { CO2, GDP, UBZ, } \\
\text { ETS }\end{array}$ & $\begin{array}{l}\text { 1. The EKC } \\
\text { Relationship is verified. }\end{array}$ \\
\hline $\begin{array}{c}\text { Saboori, } \\
\text { Sulaiman } \\
\text { and Mohd } \\
(2012 a) \\
\end{array}$ & Malaysia & $\begin{array}{c}1980- \\
2009\end{array}$ & $\begin{array}{c}\text { ARDL methodology, } \\
\text { Granger Causality } \\
\text { test based } \\
\text { on VECM } \\
\end{array}$ & CO2, GDP & $\begin{array}{l}\text { 1. Tests and confirms } \\
\text { the EKC hypothesis } \\
\text { both in long-run and } \\
\text { short-run in Malaysia. }\end{array}$ \\
\hline $\begin{array}{c}\text { Saboori, } \\
\text { Sulaiman } \\
\text { and Mohd } \\
(2016)\end{array}$ & Malaysia & $\begin{array}{c}1980- \\
2008\end{array}$ & ARDL Methodology & $\begin{array}{c}\text { CO2, GDP, } \\
\text { ERG, TDS, UBZ }\end{array}$ & $\begin{array}{l}\text { 1. The EKC } \\
\text { Relationship is verified } \\
\text { in the long-run. }\end{array}$ \\
\hline
\end{tabular}


For single-country studies, Amri (2017) and Latifa, Yang and Xu (2014) examined the EKC relationship in Algeria. Amri (2017) verified the EKC relationship in Algeria but GDP turning point was not within sample's period. Latifa, Yang and Xu (2014) verified the EKC relationship both in the long-run and short-run.

TABLE 3 CONTINUED

\begin{tabular}{|c|c|c|c|c|c|}
\hline Author(s) & Sample & Period & Methodology & Variables & Results \\
\hline $\begin{array}{l}\text { Ahmed and } \\
\text { Qazi (2014) }\end{array}$ & Mongolia & $\begin{array}{c}1980- \\
2010\end{array}$ & $\begin{array}{l}\text { Johansen } \\
\text { method of } \\
\text { cointegration } \\
\text { and granger } \\
\text { causality test } \\
\text { VECM } \\
\text { framework }\end{array}$ & $\begin{array}{l}\text { CO2, GDP, } \\
\text { ERG, TDS }\end{array}$ & $\begin{array}{l}\text { 1. Tests and confirms the EKC } \\
\text { hypothesis in Mongolia in both } \\
\text { short-run and long-run. }\end{array}$ \\
\hline $\begin{array}{l}\text { Ahmed and } \\
\text { Long (2013) }\end{array}$ & Pakistan & $\begin{array}{c}1971- \\
2008\end{array}$ & ARDL & $\begin{array}{l}\text { CO2, GDP, } \\
\text { ERG, TDS, } \\
\quad \text { PLT }\end{array}$ & $\begin{array}{l}\text { 1. Do not support EKC in a short- } \\
\text { run, whereas the long-run } \\
\text { inverted } \\
\text { U shaped hypothesis was } \\
\text { confirmed between carbon } \\
\text { emission and growth, energy } \\
\text { consumption, trade openness and } \\
\text { population density. }\end{array}$ \\
\hline $\begin{array}{l}\text { Munir and } \\
\text { Khan } \\
(\mathbf{2 0 1 4})\end{array}$ & Pakistan & $\begin{array}{c}1980- \\
2010\end{array}$ & $\begin{array}{l}\text { Johansen } \\
\text { Cointegration } \\
\text { Approach and } \\
\text { VECM }\end{array}$ & $\begin{array}{l}\text { CO2, GDP, } \\
\text { ERG, IA, } \\
\text { FCT, TDS, } \\
\text { PLT, MET, } \\
\text { MIT, ITT }\end{array}$ & $\begin{array}{l}\text { 1. The EKC Relationship is } \\
\text { verified. }\end{array}$ \\
\hline $\begin{array}{l}\text { Shahbaz, } \\
\text { Lean and } \\
\text { Shabbir } \\
(2012)\end{array}$ & Pakistan & $\begin{array}{c}1971- \\
2009\end{array}$ & $\begin{array}{l}\text { ARDL, } \\
\text { Gregory- } \\
\text { Hansen } \\
\text { Cointegration } \\
\text { Test and } \\
\text { Granger } \\
\text { Causality } \\
\text { Approach } \\
\end{array}$ & $\begin{array}{l}\text { CO2, GDP, } \\
\text { ERG, TDS }\end{array}$ & $\begin{array}{l}\text { 1. The EKC Relationship is } \\
\text { verified. }\end{array}$ \\
\hline $\begin{array}{l}\text { Shahbaz, } \\
\text { Jam, Bibi } \\
\quad \text { and } \\
\text { Loganathan } \\
(2016) \\
\end{array}$ & Portugal & $\begin{array}{c}1971- \\
2008\end{array}$ & $\begin{array}{c}\text { ARDL \& } \\
\text { Granger } \\
\text { Causality Test }\end{array}$ & $\begin{array}{l}\text { CO2, GDP, } \\
\text { ERG, TDS, } \\
\text { UBZ }\end{array}$ & $\begin{array}{l}\text { 1. The EKC hypothesis tested and } \\
\text { confirmed in both short-run and } \\
\text { long-run. }\end{array}$ \\
\hline $\begin{array}{l}\text { Balıbey } \\
\text { (2015) }\end{array}$ & Turkey & $\begin{array}{c}1974- \\
2011\end{array}$ & $\begin{array}{c}\text { Johansen } \\
\text { Cointegration } \\
\text { test, The } \\
\text { Granger } \\
\text { Causality Test } \\
\text { \& VAR (Vector } \\
\text { Autoregressive) } \\
\text { Model \& OLS } \\
\text { Regression } \\
\text { Model } \\
\end{array}$ & $\begin{array}{l}\text { CO2, GDP, } \\
\text { FIDN }\end{array}$ & $\begin{array}{l}\text { 1. The EKC hypothesis tested and } \\
\text { confirmed for Turkey by } \\
\text { quadratic specifications. }\end{array}$ \\
\hline $\begin{array}{l}\text { Katırcioglu } \\
\text { (2017) }\end{array}$ & Turkey & $\begin{array}{c}1960- \\
2010\end{array}$ & $\begin{array}{c}\text { DOLS, } \\
\text { Granger } \\
\text { Causality Test, }\end{array}$ & $\begin{array}{l}\text { CO2, GDP, } \\
\text { ERG, Oil } \\
\text { Price (OCP) }\end{array}$ & $\begin{array}{l}\text { 1. Does not Confirm the oil- } \\
\text { induced EKC hypothesis in the } \\
\text { case of Turkey. Supports the EKC }\end{array}$ \\
\hline
\end{tabular}




\begin{tabular}{|c|l|l|c|l|l|}
\hline & & $\begin{array}{c}\text { Maki } \\
\text { cointegration } \\
\text { test, ECM }\end{array}$ & hypothesis for Turkey. \\
\hline $\begin{array}{c}\text { Öztürk and } \\
\text { Öz (2016) }\end{array}$ & Turkey & $\begin{array}{c}\text { Cointegration } \\
\text { Method and } \\
\text { Granger } \\
\text { Causality } \\
\text { Analysis }\end{array}$ & $\begin{array}{c}\text { CO2, GDP, } \\
\text { ERG, FIDN }\end{array}$ & $\begin{array}{l}\text { 1. The EKC Relationship is } \\
\text { verified in the long-term and } \\
\text { short-term. }\end{array}$ \\
\hline
\end{tabular}

Tang and Tan (2016) and Yazdi and Mastorakis (2016) verified the EKC relationship in Cambodia and Iran respectively. Jalil and Mahmud (2009) and Saboori, Sulaiman and Mohd (2016) verified the EKC relationship in China and Malaysia respectively.

Can and Gozgor (2016), Saboori, Sulaiman and Mohd (2012), Ahmed and Qazi (2014) and Shahbaz, Dube, Ozturk and Jalil (2015) verified the EKC relationship both in the long-run and short-run in France, Malaysia, Mongolia and Portugal respectively.

Ahmed and Long (2013), Munir and Khan (2014) and Shahbaz, Lean and Shabbir (2012) examined the EKC relationship in Pakistan. While Munir and Khan (2014) and Shahbaz, Lean and Shabbir (2012) verified the EKC relationship in Pakistan, Ahmed and Long (2013) did not verify the EKC relationship in the short-run. Ahmed and Long (2013) verified the EKC relationship in the long-run between CO2 and GDP, energy consumption, trade openness and population density.

Balibey (2015), Katırcioglu (2017) and Öztürk and Öz (2016) examined the EKC relationship in Turkey. Balibey (2015) verified quadratic relationship between CO2 and GDP. Katırcıoglu (2017) did not verify oil-induced EKC relationship in Turkey but emission-income EKC relationship in Turkey. Öztürk and $\mathrm{Oz}$ (2016) verified the EKC relationship in Turkey both in the long-run and short-run.

\section{The EKC Relationship Not Verified}

For multi-country study, Iwata, Okada and Samreth (2012) indicated that their study does not support the EKC relationship for 11 OECD countries which are Belgium, Canada, Finland, Germany, Japan, Republic of Korea, Spain, Sweden, Switzerland, UK and USA.

For panel studies, Ozcan (2013) concluded that there was no evidence for the EKC relationship for 12 middle east countries. Martinez-Zarzoso and Bengochea-Morancho (2003) examined 19 Latin-American and Caribbean countries and found that EKC was not confirmed for panel countries. They also found heterogeneity for the EKC relationship among 19 countries and only few countries showed the EKC relationship. Among 19 countries, 9 countries showed $\mathrm{N}$-shaped curve, 2 countries showed a curve with decreasing trend, 2 countries showed U-shaped curve and 6 countries showed upward sloping curve.

Zoundi (2017), Wang (2012) and Saleh, Abedi, and Abedi (2014) tested and found no evidence for the EKC relationship for 25 countries, 98 countries and Iran respectively.

TABLE 4

STUDIES DO NOT VERIFY THE EKC RELATIONSHIP - MULTI-COUNTRY STUDIES

\begin{tabular}{|c|c|c|c|c|l|}
\hline Author(s) & Sample & Period & Methodology & Variables & \multicolumn{1}{c|}{ Results } \\
\hline $\begin{array}{c}\text { Iwata, } \\
\text { Okada } \\
\text { and } \\
\text { Samreth } \\
(2012)\end{array}$ & $\begin{array}{c}\text { 11 OECD } \\
\text { Countries }\end{array}$ & $\begin{array}{c}\text { Country } \\
\text { Based }\end{array}$ & ARDL & $\begin{array}{c}\text { CO2, GDP, ERG, } \\
\text { TDS, ES } \\
\text { (Electricity } \\
\text { Production from } \\
\text { Nuclear Source) }\end{array}$ & $\begin{array}{l}\text { 1. Does not support the EKC } \\
\text { hypothesis for 11 OECD } \\
\text { countries. }\end{array}$ \\
\hline
\end{tabular}


TABLE 5

STUDIES DO NOT VERIFY THE EKC RELATIONSHIP- PANEL STUDIES

\begin{tabular}{|c|c|c|c|c|c|}
\hline Author(s) & Sample & Period & Methodology & Variables & Results \\
\hline $\begin{array}{l}\text { Ozcan } \\
(\mathbf{2 0 1 3})\end{array}$ & $\begin{array}{l}12 \text { Middle } \\
\text { East } \\
\text { Countries }\end{array}$ & $\begin{array}{c}1990- \\
2008\end{array}$ & $\begin{array}{c}\text { Westerlund } \\
\text { panel } \\
\text { cointegration } \\
\text { test, Panel } \\
\text { FMOLS, } \\
\text { Panel-Based } \\
\text { Error } \\
\text { Correction } \\
\text { Model }\end{array}$ & $\begin{array}{l}\text { CO2, GDP, } \\
\text { ERG }\end{array}$ & $\begin{array}{l}\text { 1. The EKC Relationship is } \\
\text { not verified. }\end{array}$ \\
\hline $\begin{array}{l}\text { Martinez- } \\
\text { Zarzoso and } \\
\text { Bengochea- } \\
\text { Morancho } \\
\quad(\mathbf{2 0 0 3 )}\end{array}$ & $\begin{array}{l}19 \text { Latin- } \\
\text { American } \\
\text { and } \\
\text { Caribbean } \\
\text { countries }\end{array}$ & $\begin{array}{c}1975- \\
1998\end{array}$ & $\begin{array}{c}\text { Johansen } \\
\text { cointegration } \\
\text { test, ARDL }\end{array}$ & $\mathrm{CO2}, \mathrm{GDP}$ & $\begin{array}{l}\text { 1. EKC not confirmed for } \\
\text { panel countries. } \\
2 \text {. The } 19 \text { countries do not } \\
\text { exhibit a single behaviour for } \\
\text { the relationship between } \\
\text { CO2 and GDP. Great } \\
\text { heterogeneity is observed. } \\
\text { 3. For the EKC relationship, } \\
\text { many individual countries do } \\
\text { not verify CO2-GDP } \\
\text { relationship. } \\
9 \text { countries present a N- } \\
\text { shaped curve, } \\
2 \text { countries present a curve } \\
\text { with decreasing trend, } \\
2 \text { countries present a U- } \\
\text { shaped curve, } \\
6 \text { countries present upward } \\
\text { slopping curve. }\end{array}$ \\
\hline $\begin{array}{l}\text { Zoundi } \\
\text { (2017) }\end{array}$ & $\begin{array}{c}25 \\
\text { countries }\end{array}$ & $\begin{array}{c}1980- \\
2012\end{array}$ & $\begin{array}{c}\text { Panel } \\
\text { Cointegration } \\
\text { Approach and } \\
\text { Robustness } \\
\text { tests }\end{array}$ & $\begin{array}{c}\text { CO2, GDP, } \\
\text { ERG (Primary } \\
\text { Energy } \\
\text { Consumtpion \& } \\
\text { Renewable } \\
\text { Energy } \\
\text { Consumption), } \\
\text { PLT } \\
\end{array}$ & $\begin{array}{l}\text { 1. The EKC Relationship is } \\
\text { not verified. Tests and does } \\
\text { not confirm the existence of } \\
\text { an environmental Kuznets } \\
\text { curve. }\end{array}$ \\
\hline Wang (2012) & $\begin{array}{c}98 \\
\text { countries }\end{array}$ & $\begin{array}{c}1971- \\
2007\end{array}$ & $\begin{array}{c}\text { Dynamic Panel } \\
\text { Threshold } \\
\text { Model (DPTM) }\end{array}$ & $\mathrm{CO2}, \mathrm{GDP}$ & $\begin{array}{l}\text { 1. The EKC Relationship not } \\
\text { verified. } \\
\text { 2. In the low economic } \\
\text { growth regime, GDP } \\
\text { negatively affects } \mathrm{CO} 2 \text {. } \\
\text { 3. In the medium economic } \\
\text { growth regime, GDP } \\
\text { positively impacts } \mathrm{CO} 2 \text {. } \\
\text { 4. In the high economic } \\
\text { growth regime, the impact of } \\
\text { GDP is insignificant on } \mathrm{CO} \text {. }\end{array}$ \\
\hline $\begin{array}{l}\text { Liu, Yan } \\
\text { and Zhou } \\
(2016)\end{array}$ & China & $\begin{array}{c}1997- \\
2010\end{array}$ & $\begin{array}{c}\text { Panel } \\
\text { cointegration } \\
\text { test, Panel }\end{array}$ & $\begin{array}{l}\text { CO2, GDP, } \\
\text { UBZ (Built-up }\end{array}$ & $\begin{array}{l}\text { 1. An inverted N-shaped } \\
\text { relationship between } \mathrm{CO} 2 \\
\text { emissions and economic }\end{array}$ \\
\hline
\end{tabular}




\begin{tabular}{|c|c|c|c|c|c|}
\hline & & & $\begin{array}{c}\text { causality } \\
\text { analysis, } \\
\text { Granger } \\
\text { causality test } \\
\text { based on } \\
\text { (VECM), } \\
\text { FMOLS, } \\
\text { DOLS } \\
\end{array}$ & $\begin{array}{l}\text { Area, Urban } \\
\text { Population) }\end{array}$ & $\begin{array}{l}\text { growth in China, not } \\
\text { supporting the } \\
\text { environmental Kuznets curve } \\
\text { (EKC) hypothesis. The EKC } \\
\text { Relationship is not verified. }\end{array}$ \\
\hline $\begin{array}{l}\text { S. S. Wang, } \\
\text { Zhou, Zhou } \\
\text { and Wang } \\
(2011)\end{array}$ & China & $\begin{array}{c}1995- \\
2007\end{array}$ & $\begin{array}{c}\text { Pedroni Panel } \\
\text { cointegration } \\
\text { test, Panel } \\
\text { Granger } \\
\text { Causality Test } \\
\text { \& Panel } \\
\text { VECM } \\
\end{array}$ & $\begin{array}{l}\text { CO2, GDP, } \\
\text { ERG }\end{array}$ & $\begin{array}{l}\text { 1. The EKC Relationship is } \\
\text { not verified. Does not } \\
\text { support the EKC } \\
\text { Relationship. }\end{array}$ \\
\hline $\begin{array}{l}\text { Dogan, } \\
\text { Seker and } \\
\text { Bulbul } \\
(\mathbf{2 0 1 5})\end{array}$ & $\begin{array}{l}\text { OECD } \\
\text { Countries }\end{array}$ & $\begin{array}{c}1995- \\
2010\end{array}$ & $\begin{array}{c}\text { The Lagrange } \\
\text { multiplier } \\
\text { bootstrap } \\
\text { panel } \\
\text { cointegration, } \\
\text { DOLS, } \\
\text { Dumitrescu- } \\
\text { Hurlin Panel } \\
\text { Granger } \\
\text { Causality Test }\end{array}$ & $\begin{array}{l}\text { CO2, GDP, } \\
\text { GDP2, ERG, } \\
\text { TDS, Tourism } \\
\text { (TT) }\end{array}$ & $\begin{array}{l}\text { 1. The EKC hypothesis is not } \\
\text { verified as the sign of } \\
\text { coefficients on GDP and } \\
\text { GDP2 is negative and } \\
\text { positive, respectively. }\end{array}$ \\
\hline $\begin{array}{c}\text { Saleh, } \\
\text { Abedi, and } \\
\text { Abedi (2014) }\end{array}$ & $\begin{array}{c}\text { World } \\
\text { Bank } \\
\text { Member } \\
\text { Countries } \\
\end{array}$ & $\begin{array}{c}1990- \\
2004\end{array}$ & $\begin{array}{c}\text { VAR Model } \\
\text { with the micro } \\
\text { panel } \\
\text { application }\end{array}$ & CO2, GDP & $\begin{array}{l}\text { 1. The EKC hypothesis tested } \\
\text { and not confirmed for Iran. }\end{array}$ \\
\hline
\end{tabular}

Liu, Yan and Zhou (2016) and S. S. Wang, Zhou, Zhou and Wang (2011) tested the EKC relationship in China. While S. S. Wang, Zhou, Zhou and Wang (2011) found no evidence for the EKC relationship, Liu, Yan and Zhou (2016) found an inverted N-shaped relationship between CO2 and GDP.

For single-country studies, Ghosh, Alam and Osmani (2014) and Amin, Ferdaus and Porna (2012) tested the EKC relationship and found no evidence for the EKC relationship in Bangladesh.

Friedl and Getzner (2002) tested the EKC relationship in Austria and found no evidence for it. Saboori and Soleymani (2011), Boopen and Vinesh (2011) and Alkhathlan, Alam and Javid (2012) tested the EKC relationship and found no evidence for it in Iran, Mauritus and Saudi Arabia respectively.

Saboori, Sulaiman and Mohd (2012a) tested the EKC relationship in Indonesia. They found no evidence for the EKC relationship and GDP impacted $\mathrm{CO} 2$ negatively in the short-run and positively in the long-run.

Alege and Ogundipe (2013) examined the EKC relationship in Nigeria and found a positive linear relationship between $\mathrm{CO} 2$ and GDP.

Hussain, Javaid and Drake (2012) examined the EKC relationship in Pakistan. Hussain, Javaid and Drake (2012) found linear relationship between CO2 and GDP.

Yavuz (2014) and Dogan and Turkekul (2016) examined the EKC relationship and found no evidence for it in Turkey and USA respectively.

Farhani and Ozturk (2015), Fodha and Zaghdoud (2010) and Mrabet, Achairi and Ellouze (2014) examined the EKC relationship in Tunisia. While Farhani and Ozturk (2015) and Mrabet, Achairi and Ellouze (2014) found positive monotonic relationship between CO2 and GDP, Fodha and Zaghdoud (2010) positive monotonic relationship between $\mathrm{CO} 2$ and GDP and an inverted $\mathrm{U}$ relationship between $\mathrm{SO} 2$ emissions and GDP. 
TABLE 6

STUDIES DO NOT VERIFY THE EKC RELATIONSHIP - SINGLE-COUNTRY STUDIES

\begin{tabular}{|c|c|c|c|c|c|}
\hline Author(s) & Sample & Period & Methodology & Variables & Results \\
\hline $\begin{array}{l}\text { Ghosh, } \\
\text { Alam and } \\
\text { Osmani } \\
(2014)\end{array}$ & Bangladesh & $\begin{array}{c}1972- \\
2011\end{array}$ & $\begin{array}{c}\text { Johansen and } \\
\text { Juselius } \\
\text { Cointegration } \\
\text { Test \& VAR } \\
\text { Error } \\
\text { Correction } \\
\text { Model }\end{array}$ & CO2, GDP, ERG & $\begin{array}{l}\text { 1. The EKC Relationship is not } \\
\text { verified. }\end{array}$ \\
\hline $\begin{array}{l}\text { Friedl and } \\
\text { Getzner } \\
(2002)\end{array}$ & Austria & $\begin{array}{c}1960- \\
1999\end{array}$ & $\begin{array}{c}\text { Cointegration } \\
\text { Test, OLS } \\
\text { method }\end{array}$ & $\begin{array}{c}\text { GDP, CO2, TDS, } \\
\text { SC (Service } \\
\text { Sector) } \\
\end{array}$ & $\begin{array}{l}\text { 1. Test and rejects the EKC } \\
\text { hypothesis for Austria. }\end{array}$ \\
\hline $\begin{array}{l}\text { Amin, } \\
\text { Ferdaus } \\
\text { and Porna } \\
(\mathbf{2 0 1 2})\end{array}$ & Bangladesh & $\begin{array}{c}1976- \\
2007\end{array}$ & $\begin{array}{c}\text { Johansen } \\
\text { cointegration } \\
\text { method, } \\
\text { Granger } \\
\text { Causality \& } \\
\text { Multivariate } \\
\text { Vector Error } \\
\text { Correction } \\
\text { Model } \\
\end{array}$ & CO2, GDP, ERG & $\begin{array}{l}\text { 1. Tests and Does not Confirm } \\
\text { the existence of an } \\
\text { environmental Kuznets curve } \\
\text { for Bangladesh. }\end{array}$ \\
\hline $\begin{array}{l}\text { Saboori, } \\
\text { Sulaiman } \\
\text { and Mohd } \\
(2012 a)\end{array}$ & Indonesia & $\begin{array}{c}1971- \\
2007\end{array}$ & $\begin{array}{c}\text { Auto } \\
\text { Regressive } \\
\text { Distributed } \\
\text { Lag (ARDL) } \\
\text { methodology } \\
\text { for } \\
\text { cointegration } \\
\text { analysis, } \\
\text { ECM (Error } \\
\text { Correction } \\
\text { Model) } \\
\end{array}$ & $\begin{array}{l}\text { CO2, GDP, } \\
\text { ERG, TDS }\end{array}$ & $\begin{array}{l}\text { 1. Test EKC and do not support } \\
\text { (confirm) the EKC hypothesis, } \\
\text { which assumes an inverted U- } \\
\text { shaped relationship between } \\
\text { income and environmental } \\
\text { degradation. The EKC } \\
\text { Relationship is not verified. } \\
\text { 2. GDP impacts CO2 emissions } \\
\text { negatively in the short-run and } \\
\text { positively in the long-run. }\end{array}$ \\
\hline $\begin{array}{l}\text { Saboori } \\
\text { and } \\
\text { Soleymani } \\
(\mathbf{2 0 1 1}) \\
\end{array}$ & Iran & $\begin{array}{c}1971- \\
2007\end{array}$ & ARDL & CO2, GDP, ERG & $\begin{array}{l}\text { 1. Does not support the EKC } \\
\text { hypothesis for Iran. }\end{array}$ \\
\hline $\begin{array}{l}\text { Boopen and } \\
\text { Vinesh } \\
\text { (2011) }\end{array}$ & Mauritus & $\begin{array}{c}1975- \\
2009\end{array}$ & $\begin{array}{l}\text { Johansen } \\
\text { Cointegration } \\
\text { test \& VAR } \\
\text { Model \& } \\
\text { OLS }\end{array}$ & $\begin{array}{l}\text { CO2, GDP, ITT, } \\
\text { TDS, EL } \\
\text { (Education } \\
\text { Level), EML } \\
\text { (Employment } \\
\text { Level), PLT, } \\
\text { VEH (Number of } \\
\text { vehicles on the } \\
\text { road) }\end{array}$ & $\begin{array}{l}\text { 1. EKC not confirmed for } \\
\text { Mauritus. }\end{array}$ \\
\hline $\begin{array}{l}\text { Alege and } \\
\text { Ogundipe } \\
\text { (2013) }\end{array}$ & Nigeria & $\begin{array}{c}1970- \\
2011\end{array}$ & $\begin{array}{c}\text { Fractional } \\
\text { Integration \& } \\
\text { Co- } \\
\text { Integration } \\
\text { Analysis }\end{array}$ & $\begin{array}{l}\text { CO2, GDP, ISQ, } \\
\text { TDS, PLT }\end{array}$ & $\begin{array}{l}\text { 1. The EKC hypothesis tested } \\
\text { and not confirmed for Nigeria. } \\
\text { No evidence of EKC in Nigeria. } \\
\text { 2. Positive linear relationship } \\
\text { between GDP and } \mathrm{CO} 2 \\
\text { emissions. }\end{array}$ \\
\hline
\end{tabular}




\begin{tabular}{|c|c|c|c|c|c|}
\hline $\begin{array}{l}\text { Hussain, } \\
\text { Javaid and } \\
\text { Drake } \\
\text { (2012) }\end{array}$ & Pakistan & $\begin{array}{l}1971 \\
\text { to } \\
2006\end{array}$ & $\begin{array}{l}\text { Johansen Co- } \\
\text { integration, } \\
\text { VECM and } \\
\text { Granger } \\
\text { causality tests }\end{array}$ & $\begin{array}{l}\text { CO2, GDP, ERG } \\
\text { (Commercial } \\
\text { Energy Use) }\end{array}$ & $\begin{array}{l}\text { 1. The EKC Relationship is not } \\
\text { verified. Tests and rejects the } \\
\text { EKC relationship for Pakistan. } \\
\text { Linear relationship is observed } \\
\text { between GDP and } \mathrm{CO} 2 \text {. }\end{array}$ \\
\hline $\begin{array}{l}\text { Hussian, } \\
\text { Attari and } \\
\text { Drake } \\
(2011)\end{array}$ & Pakistan & $\begin{array}{l}1971- \\
2006\end{array}$ & $\begin{array}{c}\text { Johansen } \\
\text { Cointegration } \\
\text { Test, } \\
\text { Granger } \\
\text { Causality } \\
\text { Test, VECM } \\
\end{array}$ & $\begin{array}{l}\text { CO2, GDP, } \\
\text { ERG(commercial } \\
\text { energy use) }\end{array}$ & $\begin{array}{l}\text { 1. A monotonically increasing } \\
\text { curve between GDP and } \mathrm{CO} 2 \\
\text { emission. The EKC Relationship } \\
\text { is not verified. }\end{array}$ \\
\hline $\begin{array}{l}\text { Alkhathlan, } \\
\text { Alam and } \\
\text { Javid } \\
\text { (2012) }\end{array}$ & $\begin{array}{l}\text { Saudi } \\
\text { Arabia }\end{array}$ & $\begin{array}{l}1980- \\
2008\end{array}$ & $\begin{array}{l}\text { ARDL, } \\
\text { VECM, ECM } \\
\text { based } \\
\text { Granger } \\
\text { Causality } \\
\text { test, }\end{array}$ & $\begin{array}{l}\text { CO2, GDP, } \\
\text { ERG, EML }\end{array}$ & $\begin{array}{l}\text { 1. The EKC hypothesis does not } \\
\text { hold in the case of Saudi Arabia. }\end{array}$ \\
\hline $\begin{array}{l}\text { Farhani } \\
\text { and Ozturk } \\
\quad(2015)\end{array}$ & Tunisia & $\begin{array}{c}1971- \\
2012\end{array}$ & $\begin{array}{l}\text { ARDL, ECM } \\
\text { (Error } \\
\text { Correction } \\
\text { Method), } \\
\text { Granger } \\
\text { Causality } \\
\text { Method } \\
\end{array}$ & $\begin{array}{l}\text { CO2, GDP, } \\
\text { ERG, FCT, TDS, } \\
\text { UBZ }\end{array}$ & $\begin{array}{l}\text { 1. The } E K C \text { relationship is not } \\
\text { verified. A positive monotonic } \\
\text { relationship between real GDP } \\
\text { and } \mathrm{CO} 2 \text { emissions. }\end{array}$ \\
\hline $\begin{array}{l}\text { Fodha and } \\
\text { Zaghdoud } \\
(2010)\end{array}$ & Tunisia & $\begin{array}{c}1961- \\
2004\end{array}$ & $\begin{array}{c}\text { Johansen } \\
\text { Cointegration } \\
\text { Analysis, } \\
\text { VAR Model, } \\
\text { ECM (Error } \\
\text { Correction } \\
\text { Model), } \\
\text { Short-run } \\
\text { Granger } \\
\text { causality, } \\
\text { Long-run } \\
\text { weak } \\
\text { exogeneity } \\
\text { test }\end{array}$ & $\mathrm{CO} 2, \mathrm{SO} 2, \mathrm{GDP}$ & $\begin{array}{l}\text { 1. An inverted U relationship } \\
\text { between } \mathrm{SO} 2 \text { emissions and } \\
\text { GDP representing the EKC } \\
\text { hypothesis. } \\
\text { 2. A monotonically increasing } \\
\text { relationship between GDP and } \\
\text { CO2. }\end{array}$ \\
\hline $\begin{array}{l}\text { Mrabet, } \\
\text { Achairi and } \\
\text { Ellouze } \\
(\mathbf{2 0 1 4}) \\
\end{array}$ & Tunisia & $\begin{array}{l}1980- \\
2009\end{array}$ & VAR Model & $\mathrm{CO} 2, \mathrm{GDP}$ & $\begin{array}{l}\text { 1. The EKC Relationship is not } \\
\text { verified because monotonically } \\
\text { positive relationship between } \\
\text { GDP and } \mathrm{CO} \text {. }\end{array}$ \\
\hline $\begin{array}{l}\text { Yavuz } \\
(2014)\end{array}$ & Turkey & $\begin{array}{l}1960- \\
2007\end{array}$ & $\begin{array}{c}\text { Johansen } \\
\text { cointegration } \\
\text { test, the } \\
\text { Gregory and } \\
\text { Hansen } \\
\text { cointegration } \\
\text { test } \\
\end{array}$ & CO2, GDP, ERG & $\begin{array}{l}\text { 1. The EKC hypothesis tested } \\
\text { and not confirmed for Turkey. }\end{array}$ \\
\hline $\begin{array}{l}\text { Dogan and } \\
\text { Turkekul } \\
(2016)\end{array}$ & USA & $\begin{array}{c}1960- \\
2010\end{array}$ & $\begin{array}{c}\text { ARDL, } \\
\text { VECM } \\
\text { Granger } \\
\text { Causality } \\
\text { Test }\end{array}$ & $\begin{array}{l}\text { CO2, GDP, } \\
\text { ERG, GDP2, } \\
\text { TDS, UBZ, FCT }\end{array}$ & $\begin{array}{l}\text { 1. Does not support the } \\
\text { validity of the EKC hypothesis } \\
\text { for the USA. }\end{array}$ \\
\hline
\end{tabular}




\section{Income-Emissions Nexus}

CO2-GDP Nexus. Causality relationships and long-term and short-term relationships between $\mathrm{CO} 2$ and GDP are widely discussed in literature with panel and single-country studies.

For panel studies, Musolesi, Mazzanti and Zoboli (2010) tested EKC for a panel of 109 countries for the period between 1959 and 2001 with hierarchical bayes estimator methodology. They verified EKC for OECD, G7 and EU15 countries and concluded that there was a monotonic relationship between CO2 and GDP. Mitic', Ivanovic' and Zdravkovic (2017) examined relationship between CO2 and GDP for 17 transitional economies for the period between 1997 and 2014 with Panel Cointegration Test, DOLS and FMOLS methodologies. They found cointegrating relationship between CO2 and GDP and increase in GDP lead to an increase in CO2 in the long-run. Martinez-Zarzoso and Bengochea-Morancho (2003) tested the EKC relationship for a panel of 19 Latin-American and Caribbean countries for the period between 1975 and 1978 with Johansen cointegration test and ARDL methodologies. They discovered that there was a great heterogeneity for the relationship between CO2 and GDP for 19 Latin-American and Caribbean countries.

TABLE 7

\section{CO2 - GDP NEXUS - PANEL STUDIES}

\begin{tabular}{|c|c|c|c|c|c|}
\hline Author(s) & Sample & Period & Methodology & Variables & Results \\
\hline $\begin{array}{c}\text { Musolesi, } \\
\text { Mazzanti } \\
\text { and Zoboli } \\
(\mathbf{2 0 1 0})\end{array}$ & 109 Countries & $\begin{array}{c}1959- \\
2001\end{array}$ & $\begin{array}{c}\text { Hierarchical } \\
\text { Bayes } \\
\text { Estimator }\end{array}$ & $\begin{array}{l}\text { CO2, } \\
\text { GDP }\end{array}$ & $\begin{array}{l}\text { 1. Supports the EKC } \\
\text { hypothesis for OECD, G7 and } \\
\text { EU15 groups but does not } \\
\text { support EKC hypothesis for } \\
\text { less-developed countries. } \\
\text { 2. The EU shows a clear EKC } \\
\text { shape. } \\
\text { 3. Provides Evidence of an } \\
\text { EKC relationship between } \\
\text { CO2 and GDP, is limited to } \\
\text { the OECD, G7 and EU15 } \\
\text { groups. } \\
4 \text {. A monotonic relationship } \\
\text { between income and emissions } \\
\text { for the less-developed } \\
\text { countries. Industrialized } \\
\text { countries verify EKC in } \\
\text { quadratic specifications. }\end{array}$ \\
\hline $\begin{array}{l}\text { Mitic', } \\
\text { Ivanovic' } \\
\text { and } \\
\text { Zdravkovic } \\
\text { (2017) }\end{array}$ & $\begin{array}{l}17 \text { transitional } \\
\text { economies }\end{array}$ & $\begin{array}{c}1997- \\
2014\end{array}$ & $\begin{array}{c}\text { Panel } \\
\text { Cointegration } \\
\text { Test, DOLS } \\
\text { and FMOLS }\end{array}$ & $\begin{array}{l}\text { CO2, } \\
\text { GDP }\end{array}$ & $\begin{array}{l}\text { 1. The existence of a } \\
\text { statistically significant long- } \\
\text { run cointegrating relationship } \\
\text { between } \mathrm{CO} 2 \text { emissions and } \\
\text { real GDP. } \\
\text { 2. Increase in GDP leads to } \\
\text { increase in } \mathrm{CO} 2 \text { in the long- } \\
\text { run. }\end{array}$ \\
\hline
\end{tabular}




\begin{tabular}{|c|c|c|c|c|c|}
\hline $\begin{array}{l}\text { Martinez- } \\
\text { Zarzoso and } \\
\text { Bengochea- } \\
\text { Morancho } \\
\text { (2003) }\end{array}$ & $\begin{array}{l}19 \text { Latin- } \\
\text { American and } \\
\text { Caribbean } \\
\text { countries }\end{array}$ & $\begin{array}{c}1975- \\
1998\end{array}$ & $\begin{array}{c}\text { Johansen } \\
\text { cointegration } \\
\text { test, ARDL }\end{array}$ & $\begin{array}{l}\text { CO2, } \\
\text { GDP }\end{array}$ & $\begin{array}{l}\text { 1. EKC not confirmed for } \\
\text { panel countries. } \\
2 \text {. The } 19 \text { countries do not } \\
\text { exhibit a single behaviour for } \\
\text { the relationship between } \mathrm{CO} 2 \\
\text { and GDP. Great heterogeneity } \\
\text { is observed. } \\
\text { 3. For the EKC relationship, } \\
\text { many individual countries do } \\
\text { not verify CO2-GDP } \\
\text { relationship. } \\
9 \text { countries present a N- } \\
\text { shaped curve, } \\
2 \text { countries present a curve } \\
\text { with decreasing trend, } \\
2 \text { countries present a } U \text { - } \\
\text { shaped curve, } \\
6 \text { countries present an almost } \\
\text { lineal up-ward slopping curve. }\end{array}$ \\
\hline $\begin{array}{l}\text { Dinda and } \\
\text { Coondoo } \\
(2006)\end{array}$ & 88 Countries & $\begin{array}{c}1960- \\
1990\end{array}$ & $\begin{array}{c}\text { Engle- } \\
\text { Granger } \\
\text { Methodology } \\
\text { of Panel } \\
\text { Cointegration } \\
\text { Test, ECM }\end{array}$ & $\begin{array}{l}\text { CO2, } \\
\text { GDP }\end{array}$ & $\begin{array}{l}\text { 1. GDP } \leftrightarrow \mathrm{CO} 2 \text { for the } \\
\text { country-group of Africa. } \\
\text { 2. GDP } \rightarrow \mathrm{CO} 2 \text { for the } \\
\text { country group of Central } \\
\text { America. } \\
\text { 3. CO2 } \rightarrow \text { GDP for the } \\
\text { country-groups of Europe } \\
\text { 4. No presence of } \\
\text { cointegrating relationship } \\
\text { between the variables for the } \\
\text { country-groups of North } \\
\text { America, South America, } \\
\text { Asia, Asia excluding Japan } \\
\text { and Oceania. }\end{array}$ \\
\hline Wang (2012) & 98 countries & $\begin{array}{l}1971- \\
2007\end{array}$ & DPTM & $\begin{array}{l}\text { CO2, } \\
\text { GDP }\end{array}$ & $\begin{array}{l}\text { 1. The EKC Relationship not } \\
\text { verified. } \\
\text { 2. In the low economic growth } \\
\text { regime, GDP negatively } \\
\text { affects CO2. } \\
\text { 3. In the medium economic } \\
\text { growth regime, GDP } \\
\text { positively impacts CO2. } \\
\text { 4. In the high economic } \\
\text { growth regime, the impact of } \\
\text { GDP is insignificant on CO2. }\end{array}$ \\
\hline $\begin{array}{c}\text { Uçak et al } \\
\text { (2015) }\end{array}$ & $\begin{array}{c}\text { High-income } \\
\text { OECD } \\
\text { Countries }\end{array}$ & $\begin{array}{c}1961- \\
2004\end{array}$ & $\begin{array}{c}\text { Panel } \\
\text { Cointegration } \\
\text { Test, FMOLS, } \\
\text { DOLS, Panel } \\
\text { Granger } \\
\text { Causality Test }\end{array}$ & $\begin{array}{l}\text { CO2, } \\
\text { GDP }\end{array}$ & $\begin{array}{l}\text { 1. A long-run equilibrium } \\
\text { relationship between GDP and } \\
\text { CO2. } \\
\text { 2. In the long-run and short- } \\
\text { run; } \\
\text { GDP } \rightarrow \text { CO2 for panel study. } \\
\text { 3. For individual study; } \\
\text { GDP } \rightarrow \text { CO2 except for } \\
\text { Norway. }\end{array}$ \\
\hline
\end{tabular}




\begin{tabular}{|c|c|c|c|c|c|}
\hline $\begin{array}{l}\text { Saleh, Abedi, } \\
\text { and Abedi } \\
\text { (2014) }\end{array}$ & $\begin{array}{l}\text { World Bank } \\
\text { Member } \\
\text { Countries }\end{array}$ & $\begin{array}{c}1990- \\
2004\end{array}$ & $\begin{array}{l}\text { VAR Model } \\
\text { with the micro } \\
\text { panel } \\
\text { application }\end{array}$ & $\begin{array}{l}\text { CO2, } \\
\text { GDP }\end{array}$ & $\begin{array}{l}\text { 1. The EKC hypothesis tested } \\
\text { and not confirmed for Iran. } \\
\text { 2. For Iran; } \\
\text { GDP } \rightarrow \text { CO2 } \\
\text { 2. For subgroups of countries } \\
\text { with HGR (High Average } \\
\text { Economic Growth Rate) and } \\
\text { ROW (The Rest of the World } \\
\text { Countries); } \\
\text { GDP } \rightarrow \text { CO2 (a heterogeneous } \\
\text { one-way causality relationship } \\
\text { from GDP to CO2) } \\
\text { 3. HGR and ROW group of } \\
\text { countries should cooperate to } \\
\text { meet international goals for } \\
\text { CO2 emissions. }\end{array}$ \\
\hline
\end{tabular}

*Notes: The direction of arrow shows the way of causality

Dinda and Coondoo (2006) examined the causality relationship between CO2 and GDP for a panel of 88 countries for the period between 1960 and 1990 with Engle-Granger Methodology of Panel Cointegration Test, Error Correction Model (ECM) methodologies. They found no cointegration relationship between $\mathrm{CO} 2$ and GDP. They found bidirectional causality relationship between GDP and CO2 for the country-group of Africa, unidirectional causality running from GDP to $\mathrm{CO} 2$ for the country-group of Central America and unidirectional causality running from CO2 to GDP for the country-group of Europe.

Wang (2012) examined the relationship between CO2 and GDP for a panel of 98 countries for the period between 1971 and 2007 with Dynamic Panel Threshold Model (DPTM) methodology. Wang (2012) found that GDP negatively impacts CO2 in the low economic growth regime and GDP positively impacts $\mathrm{CO} 2$ in the medium economic growth regime.

Uçak, Aslan, Yucel and Turgut (2015) studied the relationship between CO2 and GDP for a panel of high-income OECD countries for the period between 1961 and 2004 with panel cointegration test, FMOLS, DOLS, panel granger causality test methodologies. They found that there was a long-run equilibrium relationship between $\mathrm{CO} 2$ and GDP, unidirectional causality running from GDP to $\mathrm{CO} 2$ for panel countries in the long-run and short-run, and unidirectional causality running from GDP to $\mathrm{CO} 2$ for individual countries except Norway.

Saleh, Abedi, and Abedi (2014) examined bidirectional causality relationship between CO2 and GDP for a panel of world bank member countries for the period between 1990 and 2004 with VAR Model with the micro panel application methodology.

Latifa, Yang and $\mathrm{Xu}$ (2014) studied income-environment nexus in Algeria for the period between 1965 and 2009 with ARDL, granger causality test and VECM methodologies. They found co-integrating relationship between $\mathrm{CO} 2$ and GDP, and unidirectional causality relationship from GDP to $\mathrm{CO} 2$ in the short-term and long-term.

Saboori, Sulaiman and Mohd (2012b) investigated causal relationship between CO2 and GDP in Malaysia for the period between 1980 and 2009 with ARDL and granger causality test based on VECM methodologies. They found a long-run relationship between $\mathrm{CO} 2$ and GDP, no causal relationship between $\mathrm{CO} 2$ and GDP in the short-run and unidirectional causality relationship running from GDP to CO2.

Mrabet, Achairi and Ellouze (2014) examined the two-way relationship between CO2 and GDP for the period between 1980 and 2009 with VAR model methodology. They found positive bidirectional causality between $\mathrm{CO} 2$ and GDP. 
TABLE 8

CO2 - GDP NEXUS - SINGLE-COUNTRY STUDIES

\begin{tabular}{|c|c|c|c|c|c|}
\hline Author(s) & Sample & Period & Methodology & Variables & Results \\
\hline $\begin{array}{c}\text { Latifa, } \\
\text { Yang and } \\
\text { Xu (2014) }\end{array}$ & Algeria & $\begin{array}{c}1965- \\
2009\end{array}$ & $\begin{array}{c}\text { ARDL \& } \\
\text { Granger } \\
\text { Causality Test } \\
\text { \& VECM }\end{array}$ & $\begin{array}{l}\text { CO2, } \\
\text { GDP }\end{array}$ & $\begin{array}{l}\text { 1. Long-term co-integrating } \\
\text { relationship } \\
\text { between } \mathrm{CO} 2 \text { and GDP. } \\
\text { 2. The EKC Relationship is verified } \\
\text { both in short-term and long-term. } \\
\text { 3. In the long-term and short-term; } \\
\text { GDP } \rightarrow \mathrm{CO} \text {. }\end{array}$ \\
\hline $\begin{array}{c}\text { Saboori, } \\
\text { Sulaiman } \\
\text { and Mohd } \\
(2012 b)\end{array}$ & Malaysia & $\begin{array}{c}1980- \\
2009\end{array}$ & $\begin{array}{l}\text { ARDL, Granger } \\
\text { Causality test } \\
\text { based } \\
\text { on Vector Error } \\
\text { Correction } \\
\text { Model(VECM) }\end{array}$ & $\begin{array}{l}\text { CO2, } \\
\text { GDP }\end{array}$ & $\begin{array}{l}\text { 1. Tests and confirms the EKC } \\
\text { hypothesis both in long-run and } \\
\text { short-run in Malaysia. } \\
\text { 2. A long-run relationship between } \\
\text { GDP and CO2 emissions. } \\
\text { 3. In the short-run; } \\
\text { CO2 } \neq \text { GDP } \\
\text { 4. In the long-run; } \\
\text { GDP } \rightarrow \mathrm{CO2}\end{array}$ \\
\hline $\begin{array}{l}\text { Mrabet, } \\
\text { Achairi and } \\
\text { Ellouze } \\
(2014)\end{array}$ & Tunisia & $\begin{array}{c}1980- \\
2009\end{array}$ & VAR Model & $\begin{array}{l}\text { CO2, } \\
\text { GDP }\end{array}$ & $\begin{array}{l}\text { 1. The EKC Relationship is not } \\
\text { verified because monotonically } \\
\text { positive relationship between GDP } \\
\text { and CO2. } \\
\text { 2. GDP } \leftrightarrow \mathrm{CO} 2 \text { (Positive) }\end{array}$ \\
\hline
\end{tabular}

CO2-GDP Nexus With Explanatory Variables

Causality relationships and long-term and short-term relationships between CO2 and GDP are discussed with addition of explanatory variables such as PLT, IA, ISQ, TDS, UBZ, HCD, value added in service sector (VASC), ETS, ITT, EL, EML, VEH, FCT and FIDN in the literature with panel and singlecountry studies. Different countries and time periods are taken into consideration in the literature review for CO2-GDO nexus with explanatory variables.

For panel studies, Apergis and Ozturk (2015) tested the EKC hypothesis for a panel of 14 asian countries between CO2, GDP, PLT, IA and ISQ variables for the period between 1990 and 2011 with panel co-integration tests and panel GMM methodologies. Osabuohien, Efobi and Gitau (2014) tested the EKC hypothesis for a panel of 50 african countries between CO2, GDP, GDP22, ISQ and TDS variables for the period between 1995 and 2010 with panel cointegration approach, vector autoregressive technique and PDOLS methodologies. They found a long-run relationship between CO2, GDP, GDP2, ISQ and TDS.

Liu, Yan and Zhou (2016) examined relationships between CO2, GDP and UBZ (built-up and urban population) for a panel data of 31 provinces in China at the national and regional level for the period between 1997 and 2010 with panel cointegration test, panel causality analysis, granger causality test based on VECM, FMOLS and DOLS methodologies. They found that in the long-run in China there were bidirectional relationships between UBZ (built-up) and CO2 and GDP, in the long-run in Eastern and Central China there was unidirectional causality running from UBZ (built-up) and GDP to CO2, and there was a long-term relationship between urbanization (built-up), GDP and CO2 in China. 
TABLE 9

CO2 - GDP NEXUS WITH EXPLANATORY VARIABLES- PANEL STUDIES

\begin{tabular}{|c|c|c|c|c|c|}
\hline Author(s) & Sample & Period & Methodology & Variables & Results \\
\hline $\begin{array}{c}\text { Apergis } \\
\text { and Ozturk } \\
(2015)\end{array}$ & $\begin{array}{l}14 \text { Asian } \\
\text { Countries }\end{array}$ & $\begin{array}{c}1990- \\
2011\end{array}$ & $\begin{array}{c}\text { Panel Co- } \\
\text { integration } \\
\text { Tests, Panel } \\
\text { GMM } \\
\text { Methodology }\end{array}$ & $\begin{array}{c}\text { CO2, GDP, } \\
\text { PLT, IA, ISQ } \\
\text { (Political } \\
\text { Stability, } \\
\text { Government } \\
\text { Effectiveness, } \\
\text { Quality of } \\
\text { regulation, } \\
\text { Control of } \\
\text { corruption) }\end{array}$ & $\begin{array}{l}\text { 1. The EKC Relationship is } \\
\text { verified for panel countries. }\end{array}$ \\
\hline $\begin{array}{c}\text { Osabuohien } \\
\text {, Efobi and } \\
\text { Gitau } \\
(\mathbf{2 0 1 4})\end{array}$ & $\begin{array}{l}50 \text { African } \\
\text { Countries }\end{array}$ & $\begin{array}{l}1995- \\
2010\end{array}$ & $\begin{array}{c}\text { Panel } \\
\text { Cointegration } \\
\text { Approach, } \\
\text { Vector } \\
\text { Autoregressive } \\
\text { Technique \& } \\
\text { PDOLS }\end{array}$ & $\begin{array}{c}\text { CO2, GDP, } \\
\text { GDP2, ISQ } \\
\text { (Rule of Law, } \\
\text { Regulatory } \\
\text { Quality, } \\
\text { Government } \\
\text { Effectiveness), } \\
\text { TDS }\end{array}$ & $\begin{array}{l}\text { 1. The EKC Relationship is } \\
\text { verified. Validates the EKC } \\
\text { hypothesis in Africa. } \\
\text { 2. A long-run relationship } \\
\text { exists between CO2 } \\
\text { emissions and particulate } \\
\text { matter emissions and GDP, } \\
\text { square of GDP, institutional } \\
\text { quality and trade. }\end{array}$ \\
\hline $\begin{array}{l}\text { Liu, Yan } \\
\text { and Zhou } \\
(\mathbf{2 0 1 6})\end{array}$ & China & $\begin{array}{c}1997- \\
2010\end{array}$ & $\begin{array}{c}\text { Panel } \\
\text { cointegration } \\
\text { test, Panel } \\
\text { causality } \\
\text { analysis, } \\
\text { Granger } \\
\text { causality test } \\
\text { based on vector } \\
\text { correction } \\
\text { model (VECM), } \\
\text { FMOLS, DOLS }\end{array}$ & $\begin{array}{l}\text { CO2, GDP, } \\
\text { UBZ (Built-up } \\
\text { Area, Urban } \\
\text { Population) }\end{array}$ & $\begin{array}{l}\text { 1. An inverted N-shaped } \\
\text { relationship between CO2 } \\
\text { emissions and economic } \\
\text { growth in China, not } \\
\text { supporting the EKC } \\
\text { hypothesis. The EKC } \\
\text { Relationship is not verified. } \\
\text { 2. In the long-run in China; } \\
\text { UBZ (Built-Up) } \leftrightarrow \text { GDP } \\
\text { UBZ (Built-Up) } \leftrightarrow \text { CO2 } \\
\text { GDP } \leftrightarrow \text { CO2 } \\
\text { 3. In the long-run in } \\
\text { Eastern and Central China; } \\
\text { UBZ (Built-Up) } \leftrightarrow \text { GDP } \\
\text { 4. In the short-run in } \\
\text { Eastern and Central China; } \\
\text { UBZ (Built-Up) } \rightarrow \text { CO2 } \\
\text { GDP } \rightarrow \text { CO2 } \\
5 \text {. Long-term equilibrium } \\
\text { relationship between } \\
\text { urbanization (built-up), } \\
\text { economic growth, and CO2 } \\
\text { emissions in China. }\end{array}$ \\
\hline $\begin{array}{c}\text { Lee and } \\
\text { Brahmasre } \\
\text { ne (2014) }\end{array}$ & $\begin{array}{c}\text { Nine } \\
\text { Members of } \\
\text { ASEAN }\end{array}$ & $\begin{array}{l}1991- \\
2009\end{array}$ & $\begin{array}{l}\text { Fisher-type } \\
\text { Johansen } \\
\text { cointegration } \\
\text { test, Fully } \\
\text { Modified OLS, } \\
\text { Canonical } \\
\text { Cointegrating } \\
\text { Regression \& } \\
\text { Dynamic OLS }\end{array}$ & $\begin{array}{c}\text { ICT } \\
\text { (Information } \\
\text { Communication } \\
\text { Technology), } \\
\text { CO2, GDP, } \\
\text { HCD }\end{array}$ & $\begin{array}{l}\text { 1. A long-run equilibrium } \\
\text { relationship exists among } \\
\text { these variables (ICT, CO2 } \\
\text { and GDP). } \\
\text { 2. ICT development shows a } \\
\text { highly significant positive } \\
\text { effect on economic growth } \\
\text { and CO2 emissions } \\
\text { 3. Significant to highly }\end{array}$ \\
\hline
\end{tabular}




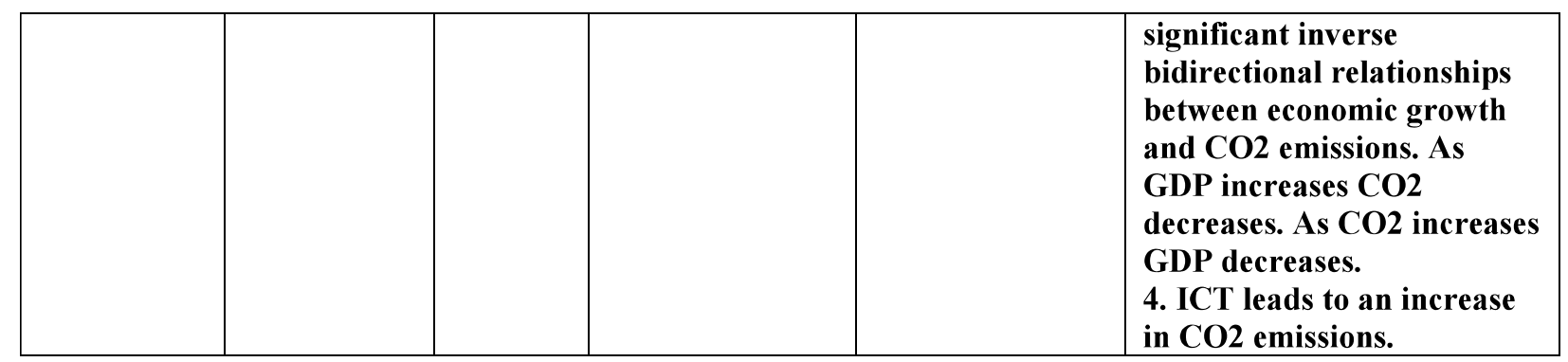

TABLE 10

CO2 - GDP NEXUS WITH EXPLANATORY VARIABLES- SINGLE-COUNTRY STUDIES

\begin{tabular}{|c|c|c|c|c|c|}
\hline Author(s) & Sample & Period & Methodology & Variables & Results \\
\hline $\begin{array}{l}\text { Friedl and } \\
\text { Getzner } \\
(2002)\end{array}$ & Austria & $\begin{array}{l}1960- \\
1999\end{array}$ & $\begin{array}{c}\text { Cointegration } \\
\text { Test, OLS } \\
\text { method }\end{array}$ & $\begin{array}{c}\text { GDP, CO2, } \\
\text { TDS, SC }\end{array}$ & $\begin{array}{l}\text { 1. Test and rejects the EKC } \\
\text { hypothesis for Austria. } \\
\text { 2. Structural changes like } \\
\text { increasing value added in the } \\
\text { service sector or higher imports } \\
\text { ratio are weakly influential on } \\
\text { CO2. }\end{array}$ \\
\hline $\begin{array}{c}\text { Pandey } \\
\text { (2016) }\end{array}$ & India & $\begin{array}{l}1961- \\
2010\end{array}$ & $\begin{array}{c}\text { Tests for Unit } \\
\text { Root, Co- } \\
\text { integration, and } \\
\text { Granger- } \\
\text { Causality Tests } \\
\text { Based on an } \\
\text { Error- } \\
\text { Correction } \\
\text { Model } \\
\end{array}$ & $\begin{array}{c}\text { CO2, GDP, } \\
\text { TDS, SC }\end{array}$ & $\begin{array}{l}\text { 1. CO2 } \rightarrow \text { GDP } \\
\text { TDS } \rightarrow \text { GDP } \\
\text { SC } \rightarrow \text { GDP } \\
\text { 2. In the short-run; } \\
\text { TDS } \leftrightarrow \text { CO2 } \\
\text { GDP } \rightarrow \text { SC }\end{array}$ \\
\hline $\begin{array}{c}\text { Yazdi and } \\
\text { Mastorakis } \\
\quad(2014)\end{array}$ & Iran & $\begin{array}{c}1975- \\
2011\end{array}$ & $\begin{array}{l}\text { ARDL \& } \\
\text { Granger } \\
\text { Causality } \\
\text { Analyses }\end{array}$ & $\begin{array}{l}\text { CO2, GDP, } \\
\text { UBZ, ETS }\end{array}$ & $\begin{array}{l}\text { 1. The EKC Relationship is } \\
\text { verified. } \\
\text { 2. } \\
\mathrm{ETS} \rightarrow \mathrm{CO2} \\
\mathrm{UBZ} \rightarrow \mathrm{CO2} \\
\mathrm{GDP} \leftrightarrow \mathrm{CO2}\end{array}$ \\
\hline $\begin{array}{l}\text { Boopen and } \\
\text { Vinesh } \\
\text { (2011) }\end{array}$ & Mauritus & $\begin{array}{l}1975- \\
2009\end{array}$ & $\begin{array}{c}\text { Johansen } \\
\text { Cointegration } \\
\text { test \& VAR } \\
\text { Model \& OLS } \\
\text { method }\end{array}$ & $\begin{array}{l}\text { CO2, GDP, } \\
\text { ITT, TDS, } \\
\text { EL, EML, } \\
\text { PLT, VEH }\end{array}$ & $\begin{array}{l}\text { 1. EKC not confirmed for } \\
\text { Mauritus. } \\
\text { 1. CO2 } \leftrightarrow \text { GDP } \\
\text { 2. Level of secondary education } \rightarrow \\
\text { CO2 (Negatively) }\end{array}$ \\
\hline $\begin{array}{l}\text { Alege and } \\
\text { Ogundipe } \\
\text { (2013) }\end{array}$ & Nigeria & $\begin{array}{l}1970- \\
2011\end{array}$ & $\begin{array}{c}\text { Fractional } \\
\text { Integration \& } \\
\text { Co-Integration } \\
\text { Analysis }\end{array}$ & $\begin{array}{l}\text { CO2, GDP, } \\
\text { ISQ, TDS, } \\
\text { PLT }\end{array}$ & $\begin{array}{l}\text { 1. The EKC hypothesis tested and } \\
\text { not confirmed for Nigeria. No } \\
\text { evidence of EKC in Nigeria. } \\
\text { 2. Positive linear relationship } \\
\text { between GDP and CO2 emissions. } \\
\text { 3. No long-run relationship } \\
\text { between variables. } \\
\text { 4. Positive relationship between } \\
\text { FIDN, TDS and CO2 emissions. } \\
\text { 5. ISQ and PLT decreases CO2 } \\
\text { emissions. }\end{array}$ \\
\hline
\end{tabular}


Lee and Brahmasrene (2014) investigated relationships between ICT, GDP and CO2 for a panel of Nine Members of ASEAN for the period between 1991 and 2009 with fisher-type johansen cointegration test, fully modified OLS, canonical cointegrating regression and dynamic OLS methodologies. They found a long-run relationship between ICT, GDP and CO2, inverse bidirectional causality between GDP and CO2, and ICT leads to an increase in $\mathrm{CO} 2$.

For single-country studies, Friedl and Getzner (2002) tested the EKC relationship and examined relationship between CO2 and GDP in Austria for the period between 1960 and 1999 with Cointegration Test and OLS methodologies. They found VASC and TDS had weak impact on CO2.

Pandey (2016) studied short-run and long-run causality relationships between CO2, GDP, SC and TDS for the period between 1961 and 2000 in India with tests for unit root, co-integration, and granger-causality tests based on error-correction model methodologies. Pandey (2016) found unidirectional causality running from CO2, TDS and SC to GDP, and in the short-run bidirectional causality between TDS and CO2 and unidirectional causality running from GDP to SC.

Yazdi and Mastorakis (2016) studied CO2, GDP, UBZ and ETS in order to investigate the determinants of CO2 in Iran for the period between 1975 and 2011 with ARDL approach and granger causality analyses methodologies. They found unidirectional causality running from ETS, UBZ and GDP to CO2.

Boopen and Vinesh (2011) examined determinants of CO2 by analyzing GDP, ITT, TDS, EL, EML, PLT and VEH in Mauritus for the period between 1975 and 2009 with johansen cointegration test, VAR model and OLS methodologies. They found bidirectional causality between CO2 and GDP and negative unidirectional causality running from level of secondary education to $\mathrm{CO} 2$.

Alege and Ogundipe (2013) studied the relationship between CO2 and GDP in Nigeria between CO2, GDP, ISQ, TDS and PLT for the period between 1970 and 2011 with fractional integration and cointegration analysis methodologies. They found no long-run relationship between variables, positive linear relationship between $\mathrm{CO} 2$ and GDP, and institutional quality and population density impacted $\mathrm{CO} 2$ negatively.

Shahbaz, Jam, Bibi and Loganathan (2016) investigated relationships between CO2, GDP, ETS and FCT in Portugal for the period between 1971 and 2011 with ARDL bounds testing approach, VECM granger causality approach and innovative accounting approach (IAA) methodologies. Shahbaz, Jam, Bibi and Loganathan (Shahbaz, Jam, et al., 2016) found unidirectional causality running from GDP and FCT to $\mathrm{CO} 2$ and bidirectional causality between ETS and CO2. While GDP and ETS increased CO2 in the longrun, FCT reduced CO2 in the long-run. Shahbaz, Jam, Bibi and Loganathan (Shahbaz, Jam, et al., 2016) suggested that authorities should invest in renewable energy and energy efficiency technologies.

\section{TABLE 10 CONTINUED}

\begin{tabular}{|c|c|c|c|c|c|}
\hline Author(s) & Sample & Period & Methodology & Variables & Results \\
\hline $\begin{array}{l}\text { Shahbaz } \\
\text { (2016a) }\end{array}$ & Portugal & $\begin{array}{l}1971- \\
2011\end{array}$ & $\begin{array}{c}\text { ARDL, VECM } \\
\text { Granger } \\
\text { Causality } \\
\text { Approach \& } \\
\text { Innovative } \\
\text { Accounting } \\
\text { Approach } \\
\text { (IAA) }\end{array}$ & $\begin{array}{l}\text { CO2, GDP, } \\
\text { ETS, FCT }\end{array}$ & $\begin{array}{l}\text { 1. Variables are cointegrated for } \\
\text { long run relationship. } \\
\text { 2. Economic growth and energy } \\
\text { intensity increase CO2 emissions. } \\
\text { 3. In the long-run; } \\
\text { ETS } \leftrightarrow \text { CO2 } \\
\text { GDP } \rightarrow \text { ETS } \\
\text { GDP } \rightarrow \text { CO2 (Authorities should } \\
\text { explore environment friendly } \\
\text { sources of energy for example } \\
\text { wind, solar and other renewable } \\
\text { energy sources as well as } \\
\text { implementation of energy efficient } \\
\text { technology) } \\
\text { FCT } \rightarrow \text { ETS } \\
\text { FCT } \rightarrow \text { CO2 (Financial }\end{array}$ \\
\hline
\end{tabular}




\begin{tabular}{|c|c|c|c|c|c|}
\hline & & & & & $\begin{array}{l}\text { development condenses } \mathrm{CO2} \\
\text { emissions) } \\
\text { 4. In the short-run; } \\
\text { GDP } \leftrightarrow \text { ETS } \\
\text { ETS } \leftrightarrow \text { CO2 } \\
\text { GDP } \leftrightarrow \text { CO2 } \\
\text { FCT } \neq \text { ETS } \\
\text { FCT } \neq \text { CO2 } \\
\text { FCT } \neq \text { GDP }\end{array}$ \\
\hline $\begin{array}{c}\text { Fodha and } \\
\text { Zaghdoud } \\
\text { (2010) }\end{array}$ & Tunisia & $\begin{array}{c}1961- \\
2004\end{array}$ & $\begin{array}{c}\text { Johansen } \\
\text { Cointegration } \\
\text { Analysis, VAR } \\
\text { Model, ECM, } \\
\text { Short-run } \\
\text { Granger } \\
\text { causality, Long- } \\
\text { run weak } \\
\text { exogeneity test }\end{array}$ & $\begin{array}{c}\mathrm{CO} 2, \mathrm{SO} 2 \\
\text { GDP }\end{array}$ & $\begin{array}{l}\text { 1. A long-run cointegrating } \\
\text { relationship between } \mathrm{CO} 2, \mathrm{SO} 2 \\
\text { and GDP. } \\
\text { 2. An inverted U relationship } \\
\text { between } \mathrm{SO} 2 \text { emissions and GDP } \\
\text { representing EKC hypothesis. } \\
\text { 3. A monotonically increasing } \\
\text { relationship between GDP and } \\
\mathrm{CO} 2 \text {. } \\
\text { 4. In the long-run and short-run; } \\
\text { GDP } \rightarrow \mathrm{SO} 2 \\
\text { GDP } \rightarrow \mathrm{CO} 2\end{array}$ \\
\hline $\begin{array}{c}\text { Balıbey } \\
\text { (2015) }\end{array}$ & Turkey & $\begin{array}{c}1974- \\
2011\end{array}$ & $\begin{array}{c}\text { Johansen } \\
\text { Cointegration } \\
\text { test, The } \\
\text { Granger } \\
\text { Causality Test } \\
\text { \& VAR Model } \\
\text { \& OLS } \\
\text { Regression } \\
\text { Model }\end{array}$ & $\begin{array}{l}\text { CO2, GDP, } \\
\text { FIDN }\end{array}$ & $\begin{array}{l}\text { 1. The EKC hypothesis tested and } \\
\text { confirmed for Turkey by } \\
\text { quadratic specifications. The EKC } \\
\text { Relationship is confirmed. } \\
\text { 2. A long-term relationship exists } \\
\text { among economic growth (GDP), } \\
\text { carbon dioxide emission (CO2) } \\
\text { and FIDN. } \\
\text { 3. In the long-run; } \\
\text { FIDN } \leftrightarrow \mathrm{CO2} \\
\text { GDP } \rightarrow \mathrm{CO2} \\
\text { GDP } \rightarrow \text { FIDN } \\
\text { 4. GDP and CO2 have a positive } \\
\text { significant effect in FIDN on the } \\
\text { long-run. } \\
5 \text {. GDP have a negative minor } \\
\text { effect on CO2 in the long-run. } \\
\text { 6. FIDN has a a significant positive } \\
\text { impact on CO2 in the long-run. }\end{array}$ \\
\hline
\end{tabular}

Notes: $\neq$ means there is no causal relationship between the variables.

Fodha and Zaghdoud (2010) examined relationships between CO2, SO2 and GDP in Tunisia for the period between 1961 and 2004 with johansen cointegration analysis, VAR Model, ECM, short-run granger causality and long-run weak exogeneity test methodologies. They found unidirectional causality running from GDP to SO2 and CO2. They discovered EKC relationship between SO2 and GDP.

Balibey (2015) tested EKC hypothesis and investigated causal relationships between CO2, GDP and FIDN in Turkey for the period between 1974 and 2011 with johansen Cointegration test, the granger causality test, VAR model and OLS regression methodologies. Balibey (2015) found unidirectional causality running from GDP to FIDN and $\mathrm{CO} 2$, and bidirectional causality between FIDN and $\mathrm{CO} 2$ in the long-run. 


\section{Energy-Emissions Nexus}

Energy consumption and carbon dioxide emissions nexus is widely investigated in the literature. In this part of the literature review, panel studies and single-country studies are examined for energy consumption and carbon dioxide emissions nexus to examine the outcomes of the studies for causality relationships and long-term and short-term relationships between energy consumption and carbon dioxide emissions with additional explanatory variables.

S. Wang, Fang, Guan, Pang and Ma (2014) investigated relationships between CO2, ERG and UBZ for a panel of 30 Chinese provinces for the period between 1995 and 2011 with panel data model, panel pedroni co-integration test, DOLS model and panel granger causality test based on VECM methodologies. They found positive bidirectional causality between $\mathrm{CO} 2$ and ERG in the long-run and in the short-run for panel provinces

Güriș (2016) studied the relationship between $\mathrm{CO} 2$ and end-use sector energy consumption, which are transportation, industrial, commercial and residential sectors, for the period between 1990 and 2011 with threshold VECM methodology. Güriș (2016) found that relationship between CO2 and ERG was different for each sector and according to that Güriș (2016) suggested that authorities should take into consideration sectoral differences for policy implications to reduce $\mathrm{CO} 2$ emissions.

TABLE 11

ERG - CO2 NEXUS - PANEL STUDIES

\begin{tabular}{|c|c|c|c|c|c|}
\hline Author(s) & Sample & Period & Methodology & Variables & Results \\
\hline $\begin{array}{l}\text { S. Wang, } \\
\text { Fang, } \\
\text { Guan, Pang } \\
\text { and Ma } \\
\text { (2014) }\end{array}$ & $\begin{array}{l}\text { China (30 } \\
\text { Chinese } \\
\text { Provinces) }\end{array}$ & $\begin{array}{l}1995- \\
2011\end{array}$ & $\begin{array}{c}\text { Panel Data } \\
\text { Model, Panel } \\
\text { Pedroni Co- } \\
\text { integration } \\
\text { Test, DOLS } \\
\text { Model, Panel } \\
\text { Granger } \\
\text { causality test } \\
\text { based on } \\
\text { VECM }\end{array}$ & $\underset{\text { UBZ }}{\mathrm{CO}, \mathrm{ERG}}$ & $\begin{array}{l}\text { 1. In the long-run; } \\
\text { UBZ } \leftrightarrow \text { ERG (Positive) } \\
\text { UBZ } \leftrightarrow \text { CO2 (Positive) } \\
\text { ERG } \leftrightarrow \text { CO2 (Positive) } \\
\text { 2. In the short-term; } \\
\text { CO2 } \leftrightarrow \text { UBZ } \\
\text { ERG } \leftrightarrow \text { CO2 } \\
\text { UBZ } \rightarrow \text { ERG }\end{array}$ \\
\hline
\end{tabular}

TABLE 12

ERG - CO2 NEXUS - SINGLE-COUNTRY STUDIES

\begin{tabular}{|c|c|c|c|c|c|}
\hline Author(s) & Sample & Period & Methodology & Variables & Results \\
\hline $\begin{array}{l}\text { Güriş } \\
\text { (2016) }\end{array}$ & $\begin{array}{l}\text { United } \\
\text { States }\end{array}$ & $\begin{array}{l}\text { 1990:01 to } \\
\text { 2011:01 } \\
\text { (Monthly) }\end{array}$ & $\begin{array}{l}\text { Threshold } \\
\text { VECM }\end{array}$ & $\begin{array}{l}\text { CO2, ERG } \\
\text { (Transport } \\
\text { ation, } \\
\text { Industrial, } \\
\text { Commercia } \\
\text { I and } \\
\text { Residential } \\
\text { Sectors) }\end{array}$ & $\begin{array}{l}\text { 1. Relationships between } \mathrm{CO} 2 \\
\text { and end-use sector energy } \\
\text { consumption are different for } \\
\text { each sector. Policy makers should } \\
\text { take into consideration sectoral } \\
\text { differences in order to reduce } \\
\text { CO2. }\end{array}$ \\
\hline
\end{tabular}

\section{Energy-Income Nexus}

Chontanawat, Hunt and Pierse (2008) investigated causal relationship between energy consumption and CO2 in 100 countries for OECD countries between 1960 and 2000, and non-OECD countries between 1971 and 2000 with johansen co-integration test, granger causality test coupled with FPE methodologies. They found unidirectional causality running from EC to GDP in 21 OECD countries and 36 non-OECD countries. 
TABLE 13

ERG - GDP NEXUS - MULTI-COUNTRY STUDIES

\begin{tabular}{|c|c|c|c|c|c|}
\hline Author(s) & Sample & Period & Methodology & Variables & Results \\
\hline $\begin{array}{l}\text { Chontanawat, } \\
\text { Hunt and } \\
\text { Pierse (2008) }\end{array}$ & $\begin{array}{c}100 \\
\text { Countries } \\
\text { (30 OECD } \\
\text { Countries } \\
\text { and } 70 \text { Non- } \\
\text { OECD } \\
\text { Countries) }\end{array}$ & $\begin{array}{c}1960-2000 \\
\text { (OECD } \\
\text { Countries) } \\
\& 1971- \\
2000 \text { (Non- } \\
\text { OECD } \\
\text { Countries) }\end{array}$ & $\begin{array}{l}\text { Johansen Co- } \\
\text { Integration } \\
\text { Test, Granger } \\
\text { Causality } \\
\text { Test coupled } \\
\text { with FPE }\end{array}$ & $\begin{array}{l}\text { GDP, } \\
\text { ERG }\end{array}$ & $\begin{array}{l}\text { 1. ERG } \rightarrow \text { GDP for } 21 \\
\text { OECD countries } \\
\text { 2. ERG } \rightarrow \text { GDP for } 36 \text { non- } \\
\text { OECD countries }\end{array}$ \\
\hline
\end{tabular}

Emissions-Income-Energy Nexus

CO2-GDP-ERG Nexus

One of the research focuses in the literature for emissions, income and energy variables is emissionsincome-energy nexus. Four hypotheses, which are neutrality hypothesis, conservation hypothesis, growth hypothesis and feedback hypothesis are tested for GDP-ERG relationship. The EKC relationship is also tested under this research focus. CO2-GDP-ERG nexus also takes into consideration additional explanatory variables to investigate the relationships between CO2, GDP and ERG. Relationships between CO2, GDP and ERG are investigated by panel studies, multi-country studies and single-country studies in the literature.

For multi-country studies, Esso and Keho (2016) found unidirectional causality running from GDP to CO2 for Benin, Democratic Republic of Congo, Ghana, Nigeria and Senegal, unidirectional causality running from CO2 to GDP for Gabon, Nigeria and Togo, and bidirectional causality between GDP and $\mathrm{CO} 2$ for Nigeria in the short-run. They also found bidirectional causality between GDP and CO2 for Congo and Gabon, unidirectional causality running from ERG to $\mathrm{CO} 2$ for Benin, Congo, $\mathrm{C}^{\wedge}$ ote $\mathrm{d}^{\prime}$ Ivoire, Gabon, Ghana, Nigeria, Senegal, South Africa and Togo, and unidirectional causality running from GDP to CO2 for Benin, Congo, $\mathrm{C}^{\wedge}$ ote d'Ivoire, Gabon, Ghana, Nigeria, Senegal, South Africa and Togo in the long-run.

Acaravci and Ozturk (2010) found unidirectional causality running from GDP and GDP2 to CO2 were found for Denmark, Italy and Greece in the short-run. In the short-run, bidirectional causality between GDP and ERG, and GDP2 and ERG were found for Switzerland. In the long-run, unidirectional causality running from ERG, GDP and GDP2 to CO2 were found for Denmark, Germany, Greece, Iceland, Italy, Portugal and Switzerland.

TABLE 14

MULTI-COUNTRY STUDIES

\begin{tabular}{|c|c|c|c|c|c|}
\hline Author(s) & Sample & Period & Methodology & Variables & Results \\
\hline $\begin{array}{c}\text { Pilatowska, } \\
\text { Wlodarczyk } \\
\text { and Zawada } \\
\text { (2015) }\end{array}$ & $\begin{array}{c}14 \text { EU } \\
\text { Countries } \\
\text { Except } \\
\text { Germany }\end{array}$ & $\begin{array}{l}1960- \\
2010\end{array}$ & $\begin{array}{l}\text { TAR Model \& } \\
\text { Momentum } \\
\text { Threshold } \\
\text { Autoregressive } \\
\text { (MTAR) Model } \\
\text { \& Non-Linear } \\
\text { Threshold } \\
\text { Cointegration }\end{array}$ & $\begin{array}{l}\text { CO2, } \\
\text { GDP, } \\
\text { ERG }\end{array}$ & $\begin{array}{l}\text { 1. The EKC hypothesis tested } \\
\text { and not confirmed for all high- } \\
\text { level and some middle-level } \\
\text { knowledge advanced } \\
\text { economies. } \\
\text { 2. The EKC hypothesis is valid } \\
\text { for all high-level and some } \\
\text { middle-level knowledge } \\
\text { advanced economies (Belgium } \\
\text { and France). }\end{array}$ \\
\hline $\begin{array}{l}\text { Esso and } \\
\text { Keho (2016) }\end{array}$ & $\begin{array}{c}12 \text { selected } \\
\text { Sub-Sahara } \\
\text { African } \\
\text { Countries }\end{array}$ & $\begin{array}{c}1971- \\
2010\end{array}$ & $\begin{array}{c}\text { Granger } \\
\text { Causality Test, } \\
\text { Cointegration } \\
\text { Bounds Testing } \\
\text { Approach }\end{array}$ & $\begin{array}{l}\text { CO2, } \\
\text { GDP, } \\
\text { ERG }\end{array}$ & $\begin{array}{l}\text { 1. In the long-run, energy } \\
\text { consumption and economic } \\
\text { growth are associated with } \\
\text { increase in atmospheric } \\
\text { pollution in most countries. }\end{array}$ \\
\hline
\end{tabular}




\begin{tabular}{|c|c|c|c|c|c|}
\hline & & & & & $\begin{array}{l}\text { (Relationship-have positive } \\
\text { effect on CO2 emissions) } \\
\text { 2. Cointegrating relationships } \\
\text { between the three variables for } \\
\text { all the countries. } \\
\text { 3. In the short-run; } \\
\text { GDP } \rightarrow \text { CO2 (Benin, } \\
\text { Democratic Republic of Congo, } \\
\text { Ghana, Nigeria and Senegal) } \\
\text { CO2 } \rightarrow \text { GDP (Gabon, Nigeria } \\
\text { and Togo) } \\
\text { GDP } \leftrightarrow \text { CO2 (Nigeria) } \\
4 . \text { In the long-run; } \\
\text { GDP } \leftrightarrow \text { CO2 (Congo and } \\
\text { Gabon) } \\
\text { ERG } \rightarrow \text { CO2 (Benin, Congo, } \\
C^{\wedge} \text { ote d'Ivoire, Gabon, Ghana, } \\
\text { Nigeria, Senegal, South Africa } \\
\text { and Togo) } \\
\text { GDP } \rightarrow \text { CO2 (Benin, Congo, } \\
C^{\wedge} \text { ote d'Ivoire, Gabon, Ghana, } \\
\text { Nigeria, Senegal, South Africa } \\
\text { and Togo) }\end{array}$ \\
\hline $\begin{array}{c}\text { Acaravci } \\
\text { and Ozturk } \\
(2010)\end{array}$ & $\begin{array}{l}19 \text { European } \\
\text { Countries }\end{array}$ & $\begin{array}{l}1960- \\
2005\end{array}$ & $\begin{array}{l}\text { ARDL, Error- } \\
\text { Correction } \\
\text { Based Granger } \\
\text { Causality Model }\end{array}$ & $\begin{array}{l}\text { CO2, } \\
\text { GDP, } \\
\text { ERG }\end{array}$ & $\begin{array}{l}\text { 1. The EKC Relationship is } \\
\text { verified for Denmark and Italy. } \\
2 \text {. In the long-run for } \\
\text { Denmark, Germany, Greece, } \\
\text { Iceland, Italy, Portugal and } \\
\text { Switzerland; } \\
\text { ERG } \rightarrow \text { CO2 } \\
\text { GDP } \rightarrow \text { CO2 } \\
\text { GDP2 } \rightarrow \text { CO2 } \\
\text { 3. In the short-run for } \\
\text { Denmark and Italy; } \\
\text { GDP } \rightarrow \text { CO2 } \\
\text { GDP2 } \rightarrow \text { CO2 } \\
4 . \text { In the short-run for Greece } \\
\text { and Italy; } \\
\text { GDP } \rightarrow \text { ERG } \\
\text { GDP2 } \rightarrow \text { ERG } \\
5 . \text { In the short-run for } \\
\text { Switzerland; } \\
\text { GDP } \leftrightarrow \text { ERG } \\
\text { GDP } \leftrightarrow \text { ERG } \\
6 . \text { A long-run relationship } \\
\text { between variables for the } \\
\text { countries of Denmark, } \\
\text { Germany, Greece, Iceland, } \\
\text { Italy, Portugal and } \\
\text { Switzerland. }\end{array}$ \\
\hline $\begin{array}{l}\text { Magazzino } \\
\text { (2016) }\end{array}$ & $\begin{array}{l}\text { Armenia, } \\
\text { Azerbaijan, } \\
\text { Georgia and } \\
\text { Turkey }\end{array}$ & $\begin{array}{c}1992- \\
2013\end{array}$ & $\begin{array}{l}\text { ARD, Gregory } \\
\text { and Hansen } \\
\text { cointegration } \\
\text { test with breaks, } \\
\text { Toda and } \\
\text { Yamamoto test, }\end{array}$ & $\begin{array}{l}\text { CO2, } \\
\text { GDP, } \\
\text { ERG }\end{array}$ & $\begin{array}{l}\text { 1. For Armenia, Conservation } \\
\text { hypothesis holds. } \\
\text { GDP } \rightarrow \text { ERG } \\
\text { GDP } \rightarrow \text { CO2 } \\
\text { 2. For Azerbaijan and Georgia, } \\
\text { both "feedback hypothesis" }\end{array}$ \\
\hline
\end{tabular}




\begin{tabular}{|c|c|c|c|c|c|}
\hline & & & $\begin{array}{l}\text { the standard } \\
\text { Granger test }\end{array}$ & & $\begin{array}{l}\text { and "growth hypothesis" holds. } \\
\text { GDP ↔ ERG (Feedback } \\
\text { Hypothesis) } \\
\text { ERG } \rightarrow \text { GDP (Growth } \\
\text { Hypothesis) } \\
\text { 3. No causality link is found for } \\
\text { Turkey, "neutrality } \\
\text { hypothesis" holds. Energy use } \\
\text { does not affect economic } \\
\text { growth, or vice versa. }\end{array}$ \\
\hline $\begin{array}{l}\text { Shahbaz, } \\
\text { Mahalik, } \\
\text { Shah and } \\
\text { Sato (2016) }\end{array}$ & $\begin{array}{c}\text { Next } 11 \\
\text { Countries }\end{array}$ & $\begin{array}{c}1972- \\
2013\end{array}$ & $\begin{array}{c}\text { Tme-varying } \\
\text { Granger } \\
\text { Causality }\end{array}$ & $\begin{array}{l}\text { CO2, } \\
\text { GDP, } \\
\text { ERG }\end{array}$ & $\begin{array}{l}\text { 1. The EKC relationship is } \\
\text { verified for Pakistan and } \\
\text { Turkey. } \\
\text { 2. In Bangladesh; } \\
\text { GDP } \rightarrow \text { ERG } \\
\text { 3. In Egypt; } \\
\text { CO2 } \rightarrow \text { GDP } \\
\text { 4. In Indonesia; } \\
\text { GDP } \rightarrow \text { CO2 } \\
\text { 5. In the Philippines; } \\
\text { ERG } \rightarrow \text { GDP } \\
\text { 6. In Pakistan; } \\
\text { CO2 } \rightarrow \text { GDP } \\
\text { 7. In Turkey, } \\
\text { GDP } \rightarrow \text { ERG } \\
\text { GDP } \rightarrow \text { CO2 } \\
\text { 8. In South Korea, } \\
\text { ERG } \leftrightarrow \text { GDP } \\
\text { 9. In Vietnam, } \\
\text { GDP } \rightarrow \text { ERG }\end{array}$ \\
\hline $\begin{array}{l}\text { Magazzino } \\
(\mathbf{2 0 1 6 b})\end{array}$ & $\begin{array}{c}\text { Six Gulf } \\
\text { Cooperation } \\
\text { Council } \\
\text { (GCC) } \\
\text { countries }\end{array}$ & $\begin{array}{l}1960- \\
2013\end{array}$ & $\begin{array}{c}\text { Johansen } \\
\text { Cointegration } \\
\text { Procedure, } \\
\text { Gregory and } \\
\text { Hansen } \\
\text { Cointegration } \\
\text { Test, Toda and } \\
\text { Yamamoto } \\
\text { Causality Test, } \\
\text { Granger Non- } \\
\text { Causality Test }\end{array}$ & $\begin{array}{l}\text { CO2, } \\
\text { GDP, } \\
\text { ERG }\end{array}$ & $\begin{array}{l}\text { 1. The existence of a clear long- } \\
\text { run relationship between } \\
\text { variables only for Oman. } \\
\text { 2. Growth Hypothesis holds } \\
\text { for three countries (Kuwait, } \\
\text { Oman, and Qatar). } \\
\text { ERG } \rightarrow \text { GDP } \\
\text { 3. Conservation Hypothesis } \\
\text { holds for Bahrain. } \\
\text { GDP } \rightarrow \text { ERG } \\
\text { 4. Feedback Hypothesis holds } \\
\text { for Saudi Arabia. } \\
\text { GDP } \leftrightarrow \text { ERG } \\
5 \text {. Neutrality Hypothesis holds } \\
\text { for United Arab Emirates. } \\
\text { GDP } \neq \text { ERG }\end{array}$ \\
\hline
\end{tabular}

Magazzino (2016) examined relationships between CO2, GDP and ERG in Armenia, Azerbaijan, Georgia and Turkey for the period between 1992 and 2013 with ARDL bounds test, Gregory and Hansen cointegration test with breaks, Toda and Yamamoto test, the standard granger test methodologies. Magazzino (2016) verified conservation hypothesis for Armenia, and also verified feedback hypothesis and growth hypothesis for Azerbaijan and Georgia, and neutrality hypothesis for Turkey.

Shahbaz, Mahalik, Shah and Sato (2016) investigated the direction of causality between CO2, GDP and ERG in Next 11 countries for the period between 1972 and 2013 with time-varying granger causality methodology. Shahbaz, Mahalik, Shah and Sato (2016) found unidirectional causality running from GDP 
to ERG for Bangladesh and Vietnam, unidirectional causality running from $\mathrm{CO} 2$ to GDP for Egypt and Pakistan, unidirectional causality running from ERG to GDP for South Korea and Philippines, unidirectional causality running from GDP to $\mathrm{CO} 2$ in Indonesia and unidirectional causality running from GDP to ERG and $\mathrm{CO} 2$ in Turkey.

Magazzino (2016b) examined relationships between CO2, GDP and ERG in six gulf cooperation council (GCC) countries for the period between 1960 and 2013 with johansen cointegration procedure, gregory and hansen cointegration test, Toda and Yamamoto causality test and granger non-causality test methodologies. Magazzino (2016b) confirmed the long-run relationship between the variables only for Oman and growth hypothesis only for Kuwait, Oman and Qatar. Magazzino (2016b) verified conservation hypothesis for Bahrain, feedback hypothesis for Saudi Arabia and neutrality hypothesis for United Arab Emirates.

For panel studies, Gmidène, Zaidi and Ghorbel (2016) examined the causal relationships between renewable energy, nuclear energy consumption, economic growth, and $\mathrm{CO} 2$ emission with panel cointegration techniques \& granger causality test methodologies. They concluded that authorities should invest in renewable energy to reduce $\mathrm{CO} 2$ emissions and decrease nuclear energy to reduce $\mathrm{CO} 2$ emissions. Arouri, Youssef, M'henni and Rault (2012) studied the relationships between GDP, CO2 and ERG in 12 MENA countries for the period between 1981 and 2005 with panel cointegration test and panel error correction model (ECM) methodologies. They found unidirectional causality running from ERG to $\mathrm{CO} 2$ in the short-run. Anastacio (2017) tested the EKC hypothesis between CO2, GDP and ERG for North American countries which were Canada, United States, Mexico, for the period between 1980 and 2008 with panel pedroni cointegration tests, panel granger causality analysis and VECM model methodologies. Anastacio (2017) unidirectional causality running from ERG and GDP to CO2 in the long-run. Mercan and Karakaya (2014) studied the causal relationships between CO2, GDP and ERG for a panel of Eleven OECD countries and Brazil for the period between 1970 and 2011 with panel cointegration test with multiple structural breaks methodology. They found that variables were cointegrated, ERG affected CO2 positively and GDP affected CO2 negatively.

Panel studies are analyzed according to neutrality hypothesis, conservation hypothesis, growth hypothesis and feedback hypothesis in the literature. Farhani and Rejeb (2012) and Asongu, Montasser and Toumi (2015) verified neutrality hypothesis for 15 Mena countries and 24 African countries respectively in the short-run. Magazzino (2016) verified neutrality hypothesis for South Caucasus area and Turkey.

Ozcan (2013), Gao and Zhang (2014), Chen et al. (2016) and Kais and Mbarek (2017) verified conservation hypothesis in the short-run for 12 middle east countries, 14 sub-sahara African countries, developed countries out of 188 countries and three North Africa countries respectively in their studies. Farhani and Rejeb (2012), Asongu, Montasser and Toumi (2015) and Wang et al. (2011) verified conservation hypothesis in the long-run for 15 Mena countries, 24 African countries and China respectively.

Alom (2014) confirmed growth hypothesis for Bangladesh, India, Pakistan, Sri Lanka and Nepal in the short-run. Magazzino (2014) tested growth hypothesis for six Asean countries and verified.

Chen et al. (2016), Wang et al. (2011), Dritsaki and Dritsaki (2014) and Apergis and Payne (2009) verified feedback hypothesis for developing countries out of 188 countries, China, and Greece, Spain and Portugal, and six Central American countries respectively in the short-run. In China, Wang et al. (2016a) and Wang et al. (2016b) confirmed feedback hypothesis. Gao and Zhang (2014), Dritsaki and Dritsaki (2014) and Kais and Mbarek (2017) verified feedback hypothesis for 14 sub-sahara African countries, Greece, Spain and Portugal, and three North African countries respectively in the long-run. 
TABLE 15

PANEL STUDIES

\begin{tabular}{|c|c|c|c|c|c|}
\hline Author(s) & Sample & Period & Methodology & Variables & Results \\
\hline $\begin{array}{c}\text { Gmidène, } \\
\text { Zaidi and } \\
\text { Ghorbel } \\
\text { (2016) }\end{array}$ & $\begin{array}{c}\text { OECD } \\
\text { Selected } \\
\text { Countries }\end{array}$ & $\begin{array}{l}1980- \\
2013\end{array}$ & $\begin{array}{c}\text { Panel } \\
\text { cointegration } \\
\text { techniques \& } \\
\text { Granger } \\
\text { Causality Test }\end{array}$ & $\begin{array}{c}\text { CO2, GDP, } \\
\text { ERG } \\
\text { (Renewable } \\
\text { Energy } \\
\text { Consumption, } \\
\text { Nuclear } \\
\text { Energy } \\
\text { Consumption) }\end{array}$ & $\begin{array}{l}\text { 1. All variables are found to } \\
\text { be cointgrated. } \\
\text { 2. In the short-run; } \\
\text { CO2 } \leftrightarrow \text { GDP } \\
\text { CO2 } \rightarrow \text { Renewable Energy } \\
\text { Consumption } \\
\text { Renewable Energy } \\
\text { Consumption } \rightarrow \text { GDP } \\
\text { Nuclear Energy } \\
\text { Consumption } \rightarrow \text { GDP } \\
3 . \text { In the long-run; } \\
\text { CO2 } \leftrightarrow \text { GDP } \\
\text { CO2 } \leftrightarrow \text { Nuclear Energy } \\
\text { Consumption } \\
\text { CO2 } \leftrightarrow \text { Renewable Energy } \\
\text { Consumption } \\
\text { GDP } \rightarrow \text { Renewable Energy } \\
\text { Consumption } \\
4 \text {. Authorities should invest } \\
\text { in renewable energy to } \\
\text { reduce CO2 and authorities } \\
\text { also should decrease nuclear } \\
\text { energy consumption to } \\
\text { reduce CO2 as well. }\end{array}$ \\
\hline $\begin{array}{l}\text { Arouri et } \\
\text { al. (2012) }\end{array}$ & $\begin{array}{l}12 \text { MENA } \\
\text { countries }\end{array}$ & $\begin{array}{l}1981- \\
2005\end{array}$ & $\begin{array}{c}\text { Panel } \\
\text { cointegration test } \\
\text { and Panel error } \\
\text { correction model } \\
\text { (ECM) }\end{array}$ & $\begin{array}{c}\text { CO2, GDP, } \\
\text { ERG }\end{array}$ & $\begin{array}{l}\text { 1. The EKC Relationship is } \\
\text { verified at the regional-level } \\
\text { but not verified at the } \\
\text { country-level. } \\
\text { 2. In the short-run; } \\
\text { ERG } \rightarrow \mathrm{CO2}\end{array}$ \\
\hline $\begin{array}{l}\text { Ozcan } \\
(2013)\end{array}$ & $\begin{array}{l}12 \text { Middle } \\
\text { East } \\
\text { Countries }\end{array}$ & $\begin{array}{l}1990- \\
2008\end{array}$ & $\begin{array}{l}\text { Westerlund } \\
\text { panel } \\
\text { cointegration } \\
\text { test, Panel } \\
\text { FMOLS, Panel- } \\
\text { Based Error } \\
\text { Correction } \\
\text { Model } \\
\end{array}$ & $\begin{array}{c}\text { CO2, GDP, } \\
\text { ERG }\end{array}$ & $\begin{array}{l}\text { 1. The EKC Relationship is } \\
\text { not verified. } \\
\text { 2. In the short-run; } \\
\text { GDP } \rightarrow \text { ERG } \\
\text { 3. In the long-run; } \\
\text { ERG } \rightarrow \text { CO2 } \\
\text { GDP } \rightarrow \text { CO2 }\end{array}$ \\
\hline $\begin{array}{l}\text { Gao and } \\
\text { Zhang } \\
\text { (2014) }\end{array}$ & $\begin{array}{c}14 \text { sub- } \\
\text { Sahara } \\
\text { African } \\
\text { (SSA) }\end{array}$ & $\begin{array}{l}1980- \\
2009\end{array}$ & $\begin{array}{c}\text { Pedroni Panel } \\
\text { Cointegration } \\
\text { and Panel vector } \\
\text { error correction } \\
\text { modelling } \\
\text { methods, } \\
\text { FMOLS \& } \\
\text { DOLS, Panel } \\
\text { Engel-Granger } \\
\text { Causality Test }\end{array}$ & $\begin{array}{c}\text { CO2, GDP, } \\
\text { ERG }\end{array}$ & $\begin{array}{l}\text { 1. The inverted U-shaped the } \\
\text { EKC hypothesis exists in the } \\
\text { SSA countries' case. The } \\
\text { EKC Relationship is } \\
\text { verified. } \\
\text { 2. In the short-run; } \\
\text { GDP } \rightarrow \text { CO2 } \\
\text { GDP } \rightarrow \text { ERG } \\
\text { CO2 } \neq \text { ERG } \\
\text { 3. In the long-run; } \\
\text { ERG } \leftrightarrow \text { GDP } \\
\text { ERG } \leftrightarrow \text { CO2 } \\
\text { GDP } \leftrightarrow \text { CO2 }\end{array}$ \\
\hline
\end{tabular}




\begin{tabular}{|c|c|c|c|c|c|}
\hline & & & & & $\begin{array}{l}\text { 4. In the long-run, ERG has } \\
\text { a statistically significant } \\
\text { positive impact on } \mathrm{CO} 2 \text {. }\end{array}$ \\
\hline $\begin{array}{l}\text { Farhani } \\
\text { and Rejeb } \\
(\mathbf{2 0 1 2})\end{array}$ & $\begin{array}{l}15 \text { MENA } \\
\text { Countries }\end{array}$ & $\begin{array}{l}1973- \\
2008\end{array}$ & $\begin{array}{l}\text { Panel Unit Root } \\
\text { Tests, Panel } \\
\text { Cointegration } \\
\text { Methods \& } \\
\text { Pedroni, Kao and } \\
\text { Johansen Panel } \\
\text { Causality Tests, } \\
\text { FMOLS \& } \\
\text { DOLS } \\
\text { approaches }\end{array}$ & $\begin{array}{l}\text { CO2, GDP, } \\
\text { ERG }\end{array}$ & $\begin{array}{l}\text { 1. In the short-run; } \\
\text { ERG } \neq \text { GDP } \\
\text { ERG } \neq \text { CO2 } \\
2 . \text { In the long-run; } \\
\text { GDP } \rightarrow \text { ERG } \\
\text { CO2 } \rightarrow \text { ERG } \\
\text { 3. A panel long- run } \\
\text { equilibrium relationship } \\
\text { between these three } \\
\text { variables, meaning that } \\
\text { energy consumption, real } \\
\text { income (GDP), and the CO2 } \\
\text { emissions move together in } \\
\text { the long run. }\end{array}$ \\
\hline $\begin{array}{l}\text { Chen et al. } \\
\text { (2016) }\end{array}$ & $\begin{array}{c}188 \\
\text { Countries }\end{array}$ & $\begin{array}{c}1993- \\
2010\end{array}$ & $\begin{array}{c}\text { ECM Panel } \\
\text { cointegration and } \\
\text { vector error- } \\
\text { correction model, } \\
\text { Dynamic Panel } \\
\text { Granger } \\
\text { Causality }\end{array}$ & $\begin{array}{l}\text { CO2, GDP, } \\
\text { ERG }\end{array}$ & $\begin{array}{l}\text { 1. Long-run relationships } \\
\text { between GDP, ERG and } \\
\text { CO2 for all countries. } \\
2 \text {. In the short-run for } \\
\text { developed countries; } \\
\text { GDP } \rightarrow \text { ERG } \\
\text { ERG does not cause GDP } \\
\text { 3. For developing countries; } \\
\text { GDP } \leftrightarrow \text { ERG } \\
\text { ERG has negative effect on } \\
\text { GDP and GDP has positive } \\
\text { effect on ERg } \\
\text { 3. In the long-run } \\
\text { relationship; } \\
\text { ERG affects GDP negatively } \\
\text { in the whole world and } \\
\text { developing countries. } \\
4 \text {. In the short-run for } \\
\text { developing and develoed } \\
\text { countries; } \\
\text { ERG } \rightarrow \text { CO2 } \\
\text { GDP } \rightarrow \text { CO2 } \\
\text { CO2 has negative effects on } \\
\text { GDP }\end{array}$ \\
\hline $\begin{array}{c}\text { Asongu, } \\
\text { Montasser } \\
\text { and Toumi } \\
(\mathbf{2 0 1 5 )}\end{array}$ & $\begin{array}{l}24 \text { African } \\
\text { Countries }\end{array}$ & $\begin{array}{c}1982- \\
2011\end{array}$ & $\begin{array}{c}\text { Pedroni's Panel } \\
\text { Cointegration } \\
\text { Test, Panel } \\
\text { ARDL } \\
\text { Approach, } \\
\text { Granger } \\
\text { Causality Test }\end{array}$ & $\begin{array}{l}\text { CO2, GDP, } \\
\text { ERG }\end{array}$ & $\begin{array}{l}\text { 1. Long run relationship } \\
\text { between energy } \\
\text { consumption, CO2 emissions } \\
\text { and GDP. } \\
\text { 2. In the long-run; } \\
\text { GDP } \rightarrow \text { ERG } \\
\text { CO2 } \rightarrow \text { ERG } \\
\text { 3. In the short-run; } \\
\text { GDP } \neq \text { CO2 Neutrality } \\
\text { Hypothesis holds No } \\
\text { causality between energy } \\
\text { consumption and economic } \\
\text { growth. }\end{array}$ \\
\hline $\begin{array}{l}\text { Alom } \\
\text { (2014) }\end{array}$ & $\begin{array}{l}\text { Banglades } \\
\text { h, India, }\end{array}$ & $\begin{array}{c}1972- \\
2010\end{array}$ & $\begin{array}{c}\text { Panel unit root } \\
\text { tests, Panel }\end{array}$ & $\begin{array}{l}\text { CO2, GDP, } \\
\text { ERG }\end{array}$ & $\begin{array}{l}\text { 1. Stable long-term } \\
\text { relationship between all }\end{array}$ \\
\hline
\end{tabular}




\begin{tabular}{|c|c|c|c|c|c|}
\hline & $\begin{array}{l}\text { Pakistan, } \\
\text { Sri Lanka } \\
\text { and Nepal }\end{array}$ & & $\begin{array}{c}\text { cointegration } \\
\text { methods and } \\
\text { Panel causality } \\
\text { test } \\
\end{array}$ & & $\begin{array}{l}\text { these variables. } \\
\text { 2. In the short-run; } \\
\text { ERG } \rightarrow \text { GDP } \\
\text { ERG } \rightarrow \text { CO2 }\end{array}$ \\
\hline $\begin{array}{c}\text { Anastacio } \\
\text { (2017) }\end{array}$ & $\begin{array}{l}\text { Canada, } \\
\text { United } \\
\text { States, } \\
\text { Mexico }\end{array}$ & $\begin{array}{l}1980- \\
2008\end{array}$ & $\begin{array}{l}\text { Panel Pedroni } \\
\text { Cointegration } \\
\text { Tests, Panel } \\
\text { Granger } \\
\text { Causality } \\
\text { Analysis, VECM } \\
\text { Model }\end{array}$ & $\begin{array}{c}\text { CO2, GDP, } \\
\text { ERG }\end{array}$ & $\begin{array}{l}\text { 1. The EKC Relationship is } \\
\text { verified for North America } \\
\text { countries (Canada, United } \\
\text { States and Mexico). } \\
\text { 2. In the long-run; for North } \\
\text { American Countries } \\
\text { ERG } \rightarrow \mathrm{CO} 2 \\
\text { GDP } \rightarrow \mathrm{CO2}\end{array}$ \\
\hline $\begin{array}{c}\text { Wang et al. } \\
\text { (2011) }\end{array}$ & China & $\begin{array}{l}1995- \\
2007\end{array}$ & $\begin{array}{c}\text { Pedroni Panel } \\
\text { cointegration } \\
\text { test, Panel } \\
\text { Granger } \\
\text { Causality Test \& } \\
\text { panel vector } \\
\text { error correction } \\
\text { modeling } \\
\text { techniques }\end{array}$ & $\begin{array}{c}\text { CO2, GDP, } \\
\text { ERG }\end{array}$ & $\begin{array}{l}\text { 1. The EKC Relationship is } \\
\text { not verified. Does not } \\
\text { support EKC Relationship. } \\
\text { 2. The long-run cointegrated } \\
\text { relationships between the } \\
\text { three vari- } \\
\text { ables. } \\
\text { 3. In the short-run; } \\
\text { CO2 } \leftrightarrow \text { ERG } \\
\text { GDP } \leftrightarrow \text { ERG } \\
\text { 4. In the long-run; } \\
\text { ERG } \rightarrow \text { CO2 } \\
\text { GDP } \rightarrow \text { CO2 } \\
\text { CO2 } \rightarrow \text { ERG } \\
\text { GDP } \rightarrow \text { ERG }\end{array}$ \\
\hline $\begin{array}{c}\text { Wang et al. } \\
\text { (2016a) }\end{array}$ & China & $\begin{array}{c}1990- \\
2012\end{array}$ & $\begin{array}{c}\text { VECM \& } \\
\text { Granger } \\
\text { Causality Test \& } \\
\text { Impulse } \\
\text { Response } \\
\text { Analysis \& } \\
\text { Johansen's } \\
\text { multivariate } \\
\text { cointegration } \\
\text { tests }\end{array}$ & $\begin{array}{c}\text { CO2, GDP, } \\
\text { ERG }\end{array}$ & $\begin{array}{l}\text { 1. Long-run relationship } \\
\text { between the variables. } \\
\text { 2. GDP } \leftrightarrow \text { ERG } \\
\text { 3. ERG } \rightarrow \mathrm{CO} 2 \\
\text { 4. GDP } \neq \mathrm{CO2}\end{array}$ \\
\hline $\begin{array}{l}\text { Wang et al. } \\
(2016 b)\end{array}$ & China & $\begin{array}{c}1995- \\
2012\end{array}$ & $\begin{array}{c}\text { Panel Pedroni } \\
\text { Cointegration } \\
\text { Test, Panel } \\
\text { Granger } \\
\text { Causality Test } \\
\text { based on VECM } \\
\end{array}$ & $\begin{array}{c}\text { CO2, GDP, } \\
\text { ERG }\end{array}$ & $\begin{array}{l}\text { 1. A long-run positive } \\
\text { relationship between } \\
\text { variables. } \\
\text { 2. GDP } \leftrightarrow \text { ERG (Positive) } \\
\text { 3. CO2 } \leftrightarrow \text { ERG (Positive) } \\
\text { 4. ERG } \rightarrow \text { CO2 (Positive) }\end{array}$ \\
\hline $\begin{array}{l}\text { Mercan } \\
\text { and } \\
\text { Karakaya } \\
(2014)\end{array}$ & $\begin{array}{l}\text { Eleven } \\
\text { OECD } \\
\text { countries } \\
\text { \& Brazil }\end{array}$ & $\begin{array}{l}1970- \\
2011\end{array}$ & $\begin{array}{c}\text { Panel } \\
\text { cointegration test } \\
\text { with multiple } \\
\text { structural breaks }\end{array}$ & $\begin{array}{c}\text { CO2, GDP, } \\
\text { ERG }\end{array}$ & $\begin{array}{l}\text { 1. Cointegration relationship } \\
\text { between GDP, ERG and } \\
\text { CO2. } \\
\text { 2. ERG affects } \mathrm{CO} 2 \\
\text { emissions positively. } \\
\text { 3. GDP affects } \mathrm{CO} 2 \\
\text { emissions negatively. }\end{array}$ \\
\hline $\begin{array}{l}\text { Dritsaki } \\
\text { and } \\
\text { Dritsaki } \\
(2014)\end{array}$ & $\begin{array}{l}\text { Greece, } \\
\text { Spain, and } \\
\text { Portugal }\end{array}$ & $\begin{array}{l}1960- \\
2009\end{array}$ & $\begin{array}{c}\text { Panel } \\
\text { Cointegration } \\
\text { Methods, Panel } \\
\text { Causality Test, } \\
\text { FMOLS, DOLS, } \\
\text { Panel Engle- } \\
\end{array}$ & $\begin{array}{c}\text { CO2, GDP, } \\
\text { ERG }\end{array}$ & $\begin{array}{l}\text { 1. In the short-run; } \\
\text { CO2 } \leftrightarrow \text { GDP } \\
\text { CO2 } \leftrightarrow \text { ERG } \\
\text { GDP } \leftrightarrow \text { ERG } \\
\text { 2. In the long-run; } \\
\text { CO2 } \rightarrow \text { ERG }\end{array}$ \\
\hline
\end{tabular}




\begin{tabular}{|c|c|c|c|c|c|}
\hline & & & $\begin{array}{c}\text { Granger } \\
\text { Causality Test, } \\
\text { ECM }\end{array}$ & & $\begin{array}{l}\text { CO2 } \rightarrow \text { GDP } \\
\text { ERG } \leftrightarrow \text { GDP } \\
\text { 3. A long-run relationship } \\
\text { between ERG, GDP and } \\
\text { CO2 emissions. They are } \\
\text { moving together in the long } \\
\text { run. }\end{array}$ \\
\hline $\begin{array}{c}\text { Magazzino } \\
\text { (2014) }\end{array}$ & $\begin{array}{c}\text { Six } \\
\text { ASEAN } \\
\text { Countries } \\
\text { (Brunei, } \\
\text { Indonesia, } \\
\text { Malaysia, } \\
\text { Singapore, } \\
\text { Thailand, } \\
\text { Philippines } \\
\text { ) } \\
\end{array}$ & $\begin{array}{c}1971- \\
2007\end{array}$ & $\begin{array}{c}\text { Panel VAR } \\
\text { technique, IRF } \\
\text { (Impulse } \\
\text { Response } \\
\text { Function) \& VD } \\
\text { (Variance } \\
\text { Decomposititon) } \\
\text { Analysis }\end{array}$ & $\begin{array}{l}\text { CO2, GDP, } \\
\text { ERG }\end{array}$ & $\begin{array}{l}\text { 1. "Growth Hypothesis" } \\
\text { holds. ERG } \rightarrow \text { GDP }\end{array}$ \\
\hline $\begin{array}{c}\text { Apergis } \\
\text { and Payne } \\
\text { (2009) }\end{array}$ & $\begin{array}{c}\text { Six } \\
\text { Central } \\
\text { American } \\
\text { Countries }\end{array}$ & $\begin{array}{l}1971- \\
2004\end{array}$ & $\begin{array}{c}\text { Panel } \\
\text { cointegration } \\
\text { test, Panel error } \\
\text { correction model, } \\
\text { FMOLS }\end{array}$ & $\begin{array}{l}\text { CO2, GDP, } \\
\text { ERG }\end{array}$ & $\begin{array}{l}\text { 1. EKC is verified. } \\
\text { 2. In the long-run; } \\
\text { ERG } \leftrightarrow \text { CO2 } \\
\text { 3. In the short-run; } \\
\text { ERG } \rightarrow \text { CO2 } \\
\text { GDP } \rightarrow \mathrm{CO2} \\
\text { ERG } \leftrightarrow \mathrm{CO2} \\
\text { ERG } \leftrightarrow \text { GDP }\end{array}$ \\
\hline$\underset{(2016 c)}{\text { Magazzino }}$ & $\begin{array}{c}\text { South } \\
\text { Caucasus } \\
\text { area and } \\
\text { Turkey }\end{array}$ & $\begin{array}{l}1992- \\
2013\end{array}$ & $\begin{array}{c}\text { Panel-Data } \\
\text { Vector } \\
\text { AutoRegression } \\
\text { (VAR) } \\
\text { Methodology }\end{array}$ & $\begin{array}{l}\text { CO2, GDP, } \\
\text { ERG }\end{array}$ & 1. GDP $\neq$ ERG \\
\hline $\begin{array}{c}\text { Kais and } \\
\text { Mbarek } \\
\text { (2017) }\end{array}$ & $\begin{array}{l}\text { Three } \\
\text { North } \\
\text { African } \\
\text { countries }\end{array}$ & $\begin{array}{l}1980- \\
2012\end{array}$ & $\begin{array}{l}\text { Panel Co- } \\
\text { integration } \\
\text { Analysis } \\
\text { (FMOLS and } \\
\text { DOLS), Granger } \\
\text { Causality \& } \\
\text { Panel VECM }\end{array}$ & $\begin{array}{l}\text { CO2, GDP, } \\
\text { ERG }\end{array}$ & $\begin{array}{l}\text { 1. In the long-run; } \\
\text { ERG } \leftrightarrow \text { GDP } \\
\text { ERG } \rightarrow \text { CO2 } \\
\text { 2. In the short-run; } \\
\text { GDP } \rightarrow \text { ERG. Conservation } \\
\text { hypothesis holds. } \\
\text { GDP } \rightarrow \text { CO2 } \\
\text { ERG } \rightarrow \text { CO2 }\end{array}$ \\
\hline
\end{tabular}

For single-country studies, Ghosh, Alam and Osmani (2014) studied the relationships between CO2, GDP and ERG in Bangladesh for the period between 1972 and 2011 with johansen and juselius cointegration test and VAR error correction model methodologies. They found that ERG had a significant positive impact on GDP and CO2 had an insignificant negative impact on GDP in the long-run. Amri (2017) examined the relationships between CO2, GDP and ERG (renewable and non-renewable energy) in Algeria for the period between 1980 and 2011 with ARDL with break point model methodology. Amri (2017) found that renewable energy consumption had an insignificant impact and non-renewable energy had significant impact on CO2 emissions. Saboori and Soleymani (2011) investigated the long-run relationship between CO2, GDP and ERG based on EKC hypothesis in Iran for the period of 1971 and 2007 with ARDL bounds test for cointegration methodology. They concluded that ERG had a significant positive impact on $\mathrm{CO} 2$ emissions in the long-run. Magazzino (2016d) examined the relationships between CO2, GDP and ERG in Italy for the period between 1970 and 2006 with vector autoregressive framework, Toda and Yamamoto granger non-causality test, johansen and juselius cointegration test and standard granger causality analysis methodologies. Magazzino (2016d) concluded that CO2, ERG and GDP were not cointegrated and there were unidirectional causality running from $\mathrm{CO} 2$ to ERG and GDP. 
Bozkurt and Akan (2014) studied the relationships between CO2, GDP and ERG in Turkey for the period between 1960 and 2010 with johansen-juselius cointegration test, VEC (Vector Error Correction) model and impulse-response analysis methodologies. Bozkurt and Akan (2014) found that variables were cointegrated, CO2 had a negative impact on GDP and ERG had a positive impact on GDP. Yavuz (2014) investigated the long-run relationship between CO2, GDP and ERG in Turkey for the period between 1960 and 2007 with Johansen cointegration test, the Gregory and Hansen cointegration test methodologies. Yavuz (2014) found that CO2, ERG and GDP were cointegrated.

Single-country studies are analyzed according to neutrality hypothesis, conservation hypothesis, growth hypothesis and feedback hypothesis in the literature. Tiwari (2011) confirmed neutrality hypothesis in India in the long-run and short-run, and Albiman, Albiman, Suleiman and Baka (2015) confirmed neutrality hypothesis in Tazmania. Chebbi and Boujelbene (2008) confirmed conservation hypothesis in Tunisia in the short-run. Mbarek, Ali and Feki (2014) verified conservation hypothesis in Tunisia. Hussain, Javaid and Drake (2012) confirmed conservation hypothesis in Pakistan, and Amin, Ferdaus and Porna (2012) and Magazzino (2015) confirmed conservation hypothesis in Bangladesh and Israel respectively. Ang (2007) and Lotfalipour, Falahi and Ashena (2010) verified conservation hypothesis in France and Iran respectively in the long-run. Tanga and Tan (2016) verified conservation hypothesis in Cambodia by concluding that there were unidirectional causality running from GDP to oil energy consumption and primary energy consumption.

Ang (2007) and Nain, Ahmad and Kamaiah (2017) confirmed growth hypothesis in the short-run in France and for aggregated level sector, industrial sector, domestic sector and commercial sector in India. Nain, Ahmad and Kamaiah (2017) confirmed growth hypothesis in India in the long-run.

Kuo, Kanyasathaporn and Lai (2014) verified feedback hypothesis in Hong Kong.

TABLE 16

SINGLE-COUNTRY STUDIES

\begin{tabular}{|c|c|c|c|c|c|}
\hline Author(s) & Sample & Period & Methodology & Variables & Results \\
\hline $\begin{array}{c}\text { Ghosh, Alam } \\
\text { and Osmani } \\
(2014)\end{array}$ & Bangladesh & $\begin{array}{c}1972- \\
2011\end{array}$ & $\begin{array}{c}\text { Johansen and } \\
\text { Juselius } \\
\text { Cointegration } \\
\text { Test \& VAR } \\
\text { Error Correction } \\
\text { Model }\end{array}$ & $\begin{array}{c}\text { CO2, GDP, } \\
\text { ERG }\end{array}$ & $\begin{array}{l}\text { 1. The EKC Relationship is } \\
\text { not verified. } \\
\text { 2. ERG has a positive and } \\
\text { significant impact on } \\
\text { economic growth for long- } \\
\text { term relationship. } \\
\text { 3. Carbon emission has a } \\
\text { negative and insignificant } \\
\text { effect on economic growth } \\
\text { for long-term relationship. }\end{array}$ \\
\hline Amri (2017) & Algeria & $\begin{array}{c}1980- \\
2011\end{array}$ & $\begin{array}{l}\text { ARDL with } \\
\text { Break Point } \\
\text { Model }\end{array}$ & $\begin{array}{l}\text { CO2, GDP, } \\
\text { ERG (Non- } \\
\text { renewable \& } \\
\text { Renewable) }\end{array}$ & $\begin{array}{l}\text { 1. The EKC Relationship is } \\
\text { verified but estimated GDP } \\
\text { turning point is not within } \\
\text { examined period. } \\
\text { 2. Significant impact of } \\
\text { non-renewable energy } \\
\text { consumption on } \mathrm{CO} 2 \text { and } \\
\text { non-significant impact of } \\
\text { renewable energy } \\
\text { consumption on } \mathrm{CO} \text {. }\end{array}$ \\
\hline $\begin{array}{l}\text { Amin, } \\
\text { Ferdaus and } \\
\text { Porna }(2012)\end{array}$ & Bangladesh & $\begin{array}{c}1976- \\
2007\end{array}$ & $\begin{array}{c}\text { Johansen } \\
\text { cointegration } \\
\text { method, Granger } \\
\text { Causality \& } \\
\text { Multivariate } \\
\text { Vector Error } \\
\end{array}$ & $\begin{array}{c}\text { CO2, GDP, } \\
\text { ERG }\end{array}$ & $\begin{array}{l}\text { 1. GDP } \neq \mathrm{CO2} \\
\text { 2. GDP } \rightarrow \text { ERG } \\
\text { 3. ERG } \rightarrow \mathrm{CO} 2 \\
\text { 4. Long run cointegration } \\
\text { among the variables. } \\
\text { 5. Policy Implication - }\end{array}$ \\
\hline
\end{tabular}




\begin{tabular}{|c|c|c|c|c|c|}
\hline & & & $\begin{array}{c}\text { Correction } \\
\text { Model }\end{array}$ & & $\begin{array}{l}\text { Economic growth in } \\
\text { Bangladesh can be achieved } \\
\text { without degrading the } \\
\text { quality of the environment } \\
6 \text {. Tests and Does Not } \\
\text { Confirm the existence of an } \\
\text { environmental Kuznets } \\
\text { curve for Bangladesh. }\end{array}$ \\
\hline $\begin{array}{l}\text { Tanga and } \\
\text { Tan }(2016)\end{array}$ & Cambodia & $\begin{array}{c}1980- \\
2010\end{array}$ & $\begin{array}{c}\text { Toda and } \\
\text { Yamamoto } \\
\text { testing method, } \\
\text { Granger non- } \\
\text { causality test and } \\
\text { ARDL }\end{array}$ & $\begin{array}{c}\text { CO2, GDP, } \\
\text { ERG (Primary } \\
\text { Consumption, } \\
\text { Oil } \\
\text { Consumption) }\end{array}$ & $\begin{array}{l}\text { 1. The EKC Relationship is } \\
\text { verified. } \\
\text { 2. GDP } \rightarrow \text { Primary Energy } \\
\text { Consumption } \\
\text { 3. GDP } \rightarrow \text { Oil Energy } \\
\text { Consumption } \\
\text { 3. Long-run relationship } \\
\text { between GDP, energy } \\
\text { consumption and CO2. } \\
\text { 4. GDP } \leftrightarrow \text { CO2 } \\
\text { 5. Oil and primary energy } \\
\text { consumptions increase } \\
\text { CO2. } \\
\text { 6. Energy consumption and } \\
\text { CO2 have no impact on } \\
\text { GDP in the long-run. } \\
\text { 7. CO2 has negative impact } \\
\text { on GDP in the short-run. }\end{array}$ \\
\hline Ang (2007) & France & $\begin{array}{c}1960- \\
2000\end{array}$ & $\begin{array}{c}\text { Johansen } \\
\text { Cointegration } \\
\text { Test, ARDL } \\
\text { Bounds Test, } \\
\text { ECM-Based } \\
\text { Granger } \\
\text { Causality Test } \\
\end{array}$ & $\begin{array}{c}\text { CO2, GDP, } \\
\text { ERG }\end{array}$ & $\begin{array}{l}\text { 1. In the long-run; } \\
\text { GDP } \rightarrow \text { CO2 } \\
\text { GDP } \rightarrow \text { ERG } \\
2 . \text { In the short-run; } \\
\text { ERG } \rightarrow \text { GDP }\end{array}$ \\
\hline $\begin{array}{c}\text { Kuo, } \\
\text { Kanyasathap } \\
\text { orn and Lai } \\
(2014)\end{array}$ & Hong Kong & $\begin{array}{c}1965- \\
2010\end{array}$ & $\begin{array}{l}\text { Johansen's co- } \\
\text { integration } \\
\text { technique, } \\
\text { Granger } \\
\text { Causality Test, } \\
\text { VECM }\end{array}$ & $\begin{array}{c}\text { CO2, GDP, } \\
\text { ERG }\end{array}$ & $\begin{array}{l}\text { 1. CO2 } \rightarrow \text { ERG } \\
\text { CO2 } \rightarrow \text { GDP } \\
\text { 2. GDP } \leftrightarrow \text { ERG } \\
\text { 3. A long-run equilibrium } \\
\text { relationship exists between } \\
\text { these variables. } \\
\text { 4. Rapid implement of } \\
\text { renewable energy, energy } \\
\text { efficiency and technological } \\
\text { diversification of energy } \\
\text { sources should be carried } \\
\text { out by authorities. }\end{array}$ \\
\hline $\begin{array}{c}\text { Nain, } \\
\text { Ahmad and } \\
\text { Kamaiah } \\
(2017)\end{array}$ & India & $\begin{array}{l}1971- \\
2011\end{array}$ & $\begin{array}{c}\text { ARDL Bounds } \\
\text { Test \& } \\
\text { TheToda- } \\
\text { Yamamoto } \\
\text { Causality Tests } \\
\text { \& VECM Model }\end{array}$ & $\begin{array}{c}\text { CO2, GDP, } \\
\text { ERG }\end{array}$ & $\begin{array}{l}\text { 1. Long-run relationship } \\
\text { among the variables } \\
\text { concerned at both } \\
\text { aggregate and disaggregate } \\
\text { levels. (in all the sectors } \\
\text { included in the study, } \\
\text { namely, agriculture, } \\
\text { domestic, industrial and } \\
\text { commercial, and also at the } \\
\text { aggregated level) } \\
\text { 2. In the short-run at the }\end{array}$ \\
\hline
\end{tabular}




\begin{tabular}{|c|c|c|c|c|c|}
\hline & & & & & $\begin{array}{l}\text { aggregated level \& the } \\
\text { industrial sector; } \\
\text { ERG } \rightarrow \text { GDP } \\
\text { 3. In the short run and in } \\
\text { the long run for domestic } \\
\text { and commercial sectors; } \\
\text { ERG } \rightarrow \text { GDP } \\
\text { 4. In all sectors and at the } \\
\text { aggregated level in both } \\
\text { short-run and long-run; } \\
\text { CO2 } \rightarrow \text { GDP } \\
\text { 5. At the aggregated level in } \\
\text { the short-run and long-run; } \\
\text { ERG } \leftrightarrow \text { CO2 } \\
\text { 6.At the sectoral level (in } \\
\text { agriculture and domestic } \\
\text { sectors) } \\
\text { ERG } \rightarrow \text { CO2 } \\
\text { ERG } \neq \text { CO2 (In Industrial } \\
\text { Sector) } \\
\text { CO2 } \rightarrow \text { ERG (In } \\
\text { Commercial Sector) } \\
\text { 7. Short-run causal } \\
\text { relationship among the } \\
\text { variables is not uniform } \\
\text { across sectors. }\end{array}$ \\
\hline $\begin{array}{l}\text { Tiwari } \\
\text { (2011) }\end{array}$ & India & $\begin{array}{l}1971- \\
2005\end{array}$ & $\begin{array}{c}\text { Johansen \& } \\
\text { Juselius } \\
\text { Cointegration } \\
\text { Test, Engle- } \\
\text { Granger } \\
\text { approach } \\
\text { (VECM } \\
\text { framework), } \\
\text { Dolado and } \\
\text { Lütkepohlees } \\
\text { approach, VEC } \\
\text { Lag Exclusion } \\
\text { Wald Tests, IRF } \\
\text { (Impulse } \\
\text { Response } \\
\text { Function) \& VD } \\
\text { (Variance } \\
\text { Decomposititon) } \\
\text { Analysis } \\
\end{array}$ & $\begin{array}{c}\text { CO2, GDP, } \\
\text { ERG }\end{array}$ & $\begin{array}{l}1 . \text { In the short-run; } \\
\mathrm{CO} 2 \rightarrow \text { GDP } \\
\text { Energy consumption does } \\
\text { not Granger-cause GDP } \\
\text { GDP does not Granger- } \\
\text { cause } \mathrm{CO2} \text { in the short-run. } \\
\text { ERG } \rightarrow \mathrm{CO2} \\
\mathrm{CO} 2 \rightarrow \text { ERG } \\
\text { GDP does not } \\
\text { Grangercauses CO2 } \\
\text { emissions } \\
2 . \text { In the long-run; } \\
\text { GDP } \rightarrow \mathrm{CO2} \\
\text { ERG } \rightarrow \mathrm{CO2}\end{array}$ \\
\hline $\begin{array}{c}\text { Lotfalipour, } \\
\text { Falahi and } \\
\text { Ashena } \\
(2010)\end{array}$ & Iran & $\begin{array}{c}1967- \\
2007\end{array}$ & $\begin{array}{c}\text { Toda-Yamamoto } \\
\text { Method }\end{array}$ & $\begin{array}{c}\text { CO2, GDP, } \\
\text { ERG } \\
\text { (Petroleum } \\
\text { Products } \\
\text { Consumption, } \\
\text { Natural Gas } \\
\text { Consumption } \\
\text { and Total } \\
\text { Fossil Fuels } \\
\text { Consumption) }\end{array}$ & $\begin{array}{l}\text { 1. In the long-run; } \\
\text { ERG } \rightarrow \mathrm{CO} 2 \\
\text { Natural Gas Consumption } \\
\rightarrow \mathrm{CO} 2 \\
\text { Petroleum Products } \\
\text { Consumption } \rightarrow \mathrm{CO2} \\
\text { GDP } \rightarrow \text { Total Fossil Fuels } \\
\text { Consumption } \\
\text { GDP } \rightarrow \text { Petroleum } \\
\text { Products Consumption } \\
\text { GDP } \rightarrow \mathrm{CO} 2\end{array}$ \\
\hline
\end{tabular}




\begin{tabular}{|c|c|c|c|c|c|}
\hline & & & & & $\begin{array}{l}\text { Petroleum Products } \\
\text { Consumption } \rightarrow \mathrm{CO} 2 \\
\text { Gas Consumption } \rightarrow \mathrm{CO} 2 \\
\text { Total Fossil Fuels } \\
\text { Consumption } \neq \mathrm{CO} 2 \\
\text { GDP } \rightarrow \text { ERG }\end{array}$ \\
\hline $\begin{array}{l}\text { Saboori and } \\
\text { Soleymani } \\
\quad(2011)\end{array}$ & Iran & $\begin{array}{l}1971- \\
2007\end{array}$ & $\begin{array}{l}\text { ARDL bounds } \\
\text { test for } \\
\text { cointegration }\end{array}$ & $\begin{array}{c}\text { CO2, GDP, } \\
\text { ERG }\end{array}$ & $\begin{array}{l}\text { 1. Does not support EKC } \\
\text { hypothesis for Iran. } \\
\text { 2. In the long-run; } \\
\text { ERG has a positive and } \\
\text { significant impact on } \mathrm{CO} \text {. }\end{array}$ \\
\hline $\begin{array}{c}\text { Magazzino } \\
\text { (2015) }\end{array}$ & Israel & $\begin{array}{c}1971- \\
2006\end{array}$ & $\begin{array}{c}\text { Johansen and } \\
\text { Juselius } \\
\text { Cointegration } \\
\text { Test, Toda and } \\
\text { Yamamoto \& } \\
\text { Granger non- } \\
\text { causality Tests }\end{array}$ & $\begin{array}{c}\text { CO2, GDP, } \\
\text { ERG }\end{array}$ & $\begin{array}{l}\text { 1. GDP } \rightarrow \text { ERG } \\
\text { Conservation hypothesis } \\
\text { verified as an increase in } \\
\text { GDP causes an increase in } \\
\text { energy conumption. } \\
\text { 2. CO2 } \rightarrow \text { GDP } \\
\text { GDP } \rightarrow \text { ERG } \\
\text { 3. Long-run relationship } \\
\text { between these variables. }\end{array}$ \\
\hline $\begin{array}{c}\text { Magazzino } \\
\text { (2016d) }\end{array}$ & Italy & $\begin{array}{l}1970- \\
2006\end{array}$ & $\begin{array}{c}\text { Vector } \\
\text { Autoregressive } \\
\text { Framework, } \\
\text { Toda and } \\
\text { Yamamoto } \\
\text { Granger non- } \\
\text { causality test, } \\
\text { Johansen and } \\
\text { Juselius } \\
\text { cointegration } \\
\text { test, Standard } \\
\text { Granger } \\
\text { causality analysis } \\
\end{array}$ & $\begin{array}{c}\text { CO2, GDP, } \\
\text { ERG }\end{array}$ & $\begin{array}{l}\text { 1. } \mathrm{CO} 2 \text { emissions, energy } \\
\text { consumption and economic } \\
\text { growth are not } \\
\text { cointegrated. } \\
\text { 2. } \mathrm{CO} 2 \leftrightarrow \text { GDP } \\
\mathrm{CO} 2 \leftrightarrow \text { ERG }\end{array}$ \\
\hline $\begin{array}{c}\text { Hussain, } \\
\text { Javaid and } \\
\text { Drake (2012) }\end{array}$ & Pakistan & $\begin{array}{l}1971 \\
\text { to } \\
2006\end{array}$ & $\begin{array}{c}\text { Johansen Co- } \\
\text { integration, } \\
\text { VECM and } \\
\text { Granger } \\
\text { causality tests }\end{array}$ & $\begin{array}{c}\text { CO2, GDP, } \\
\text { ERG } \\
\text { (Commercial } \\
\text { Energy Use) }\end{array}$ & $\begin{array}{l}\text { 1. The EKC Relationship is } \\
\text { not verified. Tests and } \\
\text { rejects EKC relationship } \\
\text { for Pakistan. Linear } \\
\text { relationship is observed } \\
\text { between GDP and CO2. } \\
\text { 2. CO2 } \leftrightarrow \text { ERG } \\
\text { 3. GDP } \rightarrow \text { CO2 } \\
\text { GDP } \rightarrow \text { ERG }\end{array}$ \\
\hline $\begin{array}{c}\text { Albiman, } \\
\text { Suleiman } \\
\text { and Baka } \\
(2015)\end{array}$ & Tanzania & $\begin{array}{l}1975- \\
2013\end{array}$ & $\begin{array}{c}\text { Toda and } \\
\text { Yamamoto non- } \\
\text { Causality test, } \\
\text { Impulse } \\
\text { Response and } \\
\text { Variance } \\
\text { Decomposition }\end{array}$ & $\begin{array}{c}\text { CO2, GDP, } \\
\text { ERG }\end{array}$ & $\begin{array}{l}\text { 1. No causality relationship } \\
\text { running from energy } \\
\text { consumption and carbon } \\
\text { emission toward economic } \\
\text { growth (no unidirectional } \\
\text { causality from carbon } \\
\text { emission and economic } \\
\text { growth to the energy } \\
\text { consumption). } \\
\text { 2. GDP } \rightarrow \mathrm{CO} 2 \\
\text { ERG } \rightarrow \mathrm{CO} 2\end{array}$ \\
\hline $\begin{array}{l}\text { Chebbi and } \\
\text { Boujelbene } \\
(2008) \\
\end{array}$ & Tunisia & $\begin{array}{c}1971- \\
2004\end{array}$ & $\begin{array}{c}\text { Johansen } \\
\text { Cointegration } \\
\text { Test, Johansen \& } \\
\end{array}$ & $\begin{array}{l}\text { CO2, GDP, } \\
\text { ERG }\end{array}$ & $\begin{array}{l}\text { 1. GDP and energy } \\
\text { consumption are positively } \\
\text { related in the long-run. }\end{array}$ \\
\hline
\end{tabular}




\begin{tabular}{|c|c|c|c|c|c|}
\hline & & & $\begin{array}{c}\text { Juselius } \\
\text { Cointegration } \\
\text { Test, Generalized } \\
\text { Impulse } \\
\text { Response } \\
\text { Functions } \\
\text { (GIRF) }\end{array}$ & & $\begin{array}{l}\text { 2. CO2 emissions and } \\
\text { energy consumption are } \\
\text { positively related in the } \\
\text { long-run. } \\
\text { 3. In the short run, } \\
\text { GDP } \rightarrow \text { ERG }\end{array}$ \\
\hline $\begin{array}{l}\text { Mbarek, Ali } \\
\text { and Feki } \\
(2014)\end{array}$ & Tunisia & $\begin{array}{l}1980- \\
2009\end{array}$ & $\begin{array}{c}\text { Granger } \\
\text { Causality Test \& } \\
\text { VAR Model }\end{array}$ & $\begin{array}{c}\text { CO2, GDP, } \\
\text { ERG }\end{array}$ & $\begin{array}{l}\text { 1. ERG } \leftrightarrow \mathrm{CO} 2 \\
\text { 2. GDP } \rightarrow \text { ERG }\end{array}$ \\
\hline $\begin{array}{l}\text { Bozkurt and } \\
\text { Akan (2014) }\end{array}$ & Turkey & $\begin{array}{c}1960- \\
2010\end{array}$ & $\begin{array}{c}\text { Johansen- } \\
\text { Juselius } \\
\text { Cointegration } \\
\text { Test, VEC } \\
\text { Model, Impulse- } \\
\text { response analysis }\end{array}$ & $\begin{array}{c}\text { CO2, GDP, } \\
\text { ERG }\end{array}$ & $\begin{array}{l}\text { 1. CO2 affect negatively } \\
\text { economic growth. } \\
\text { 2. A long-term relationship } \\
\text { between variables. } \\
\text { 3. ERG has a positive } \\
\text { impact on economic } \\
\text { growth. }\end{array}$ \\
\hline Yavuz (2014) & Turkey & $\begin{array}{c}1960- \\
2007\end{array}$ & $\begin{array}{c}\text { Johansen } \\
\text { cointegration } \\
\text { test, the Gregory } \\
\text { and Hansen } \\
\text { cointegration test }\end{array}$ & $\begin{array}{c}\text { CO2, GDP, } \\
\text { ERG }\end{array}$ & $\begin{array}{l}\text { 1. The EKC hypothesis } \\
\text { tested and not confirmed } \\
\text { for Turkey. } \\
\text { 2. A long-run relationship } \\
\text { between CO2 emissions, } \\
\text { ERG and GDP. }\end{array}$ \\
\hline
\end{tabular}

\section{CO2-GDP-ERG Nexus With Explanatory Variables}

CO2-GDP-ERG-URZ. Wang, Li and Fang (2017) examined the relationships between CO2, GDP, ERG and UBZ for a panel of 170 Countries (Global Panel, High-Income, Upper-Middle-Income, LowerMiddle-Income and Low-Income) for the period between 1980 and 2011 with panel data modelling, panel cointegration test, panel granger causality test based on VECM, impulse response and variance decomposition analysis methodologies. Variables were found cointegrated for all country groups such as global panel, high-income, upper-middle-income, lower-middle-income and low-income. Wang, Li and Fang (2017) verified conservation hypothesis for upper-middle-income country group in the long-run and short-run, and feedback hypothesis for high-income and low-income country groups in the long-run and short-run. Wang, Li and Fang (2017) also confirmed growth hypothesis for lower-middle-income country group in the long-run and feedback hypothesis for lower-middle-income country group in the short-run.

TABLE 17

CO2-GDP-ERG-UBZ FOR PANEL STUDIES

\begin{tabular}{|c|c|c|c|c|c|}
\hline Author(s) & Sample & Period & Methodology & Variables & Results \\
\hline $\begin{array}{c}\text { Wang, Li } \\
\text { and Fang } \\
\text { (2017) }\end{array}$ & $\begin{array}{l}170 \\
\text { Countries } \\
\text { (Global } \\
\text { Panel, } \\
\text { High-- } \\
\text { Income, } \\
\text { Upper- } \\
\text { Middle- } \\
\text { Income, } \\
\text { Lower- } \\
\text { Middle- } \\
\text { Income and } \\
\text { Low- } \\
\text { Income) }\end{array}$ & $\begin{array}{c}1980- \\
2011\end{array}$ & $\begin{array}{l}\text { Panel Data } \\
\text { Modelling, } \\
\text { Panel } \\
\text { Cointegration } \\
\text { Test, Panel } \\
\text { Granger } \\
\text { causality test } \\
\text { based on the } \\
\text { VECM, impulse } \\
\text { response and } \\
\text { variance } \\
\text { decomposition } \\
\text { analysis }\end{array}$ & $\begin{array}{l}\text { CO2, GDP, } \\
\text { ERG, UBZ }\end{array}$ & $\begin{array}{l}\text { 1. Variables are cointegrated for } \\
\text { all of the income-based country } \\
\text { groups. } \\
\text { 2. In the long-run for High- } \\
\text { income econonmies; } \\
\text { ERG } \leftrightarrow \text { GDP } \\
\text { CO2 } \rightarrow \text { GDP } \\
\text { CO2 } \rightarrow \text { ERG } \\
\text { UBZ } \rightarrow \text { ERG } \\
\text { UBZ } \rightarrow \text { GDP } \\
\text { 3. In the short-run for High- } \\
\text { income economies; } \\
\text { CO2 } \leftrightarrow \text { GDP } \\
\text { ERG } \leftrightarrow \text { GDP }\end{array}$ \\
\hline
\end{tabular}




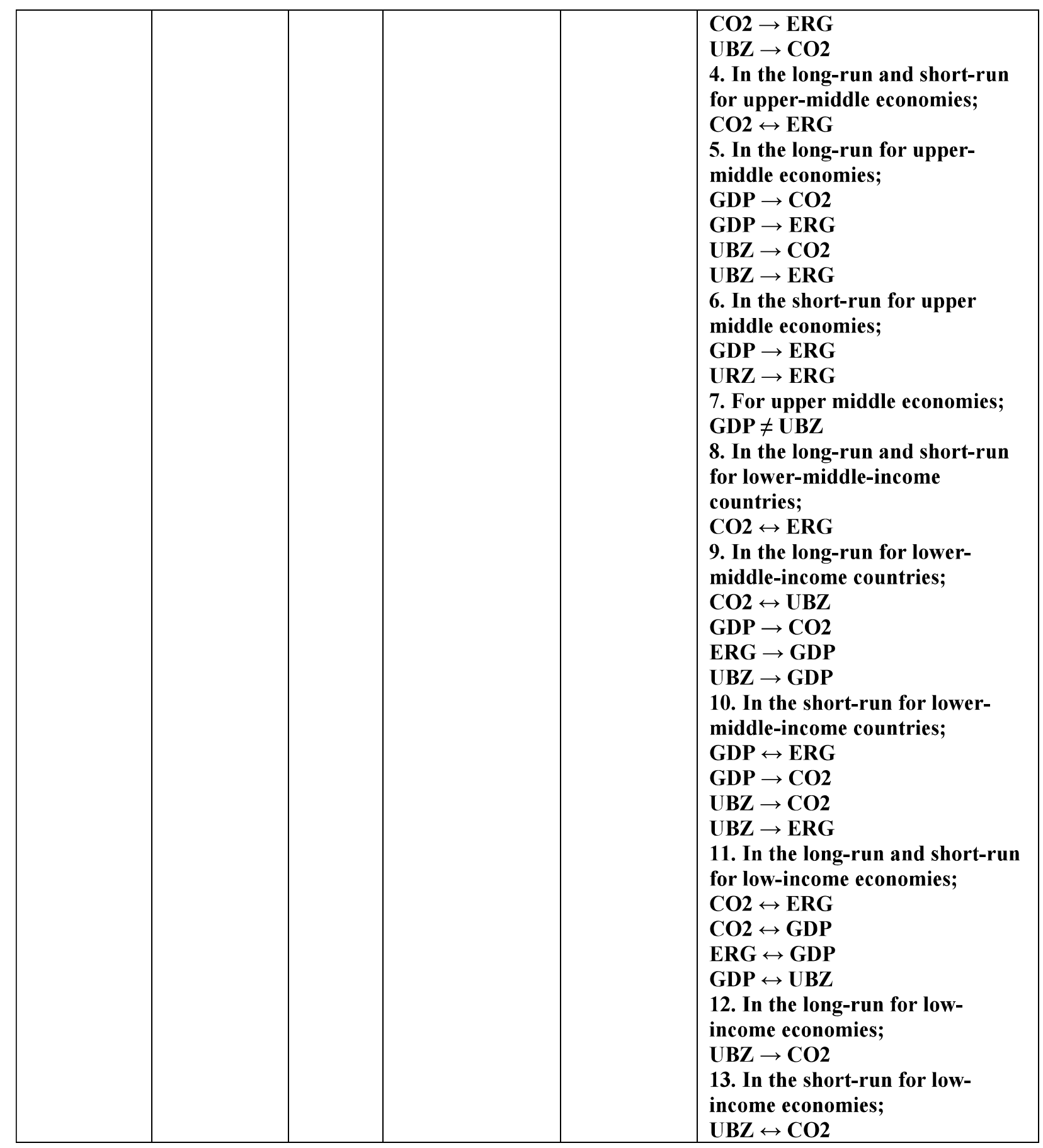

CO2-GDP-ERG-TO-UBZ

Destek, Ball 1 and Manga (2016) studied the relationships between CO2, ERG, GDP, TDS and UBZ for a panel of Central and Eastern European Countries (CEECs) for the period between 1991 and 2011 with panel cointegration method, FMOLS, DOLS and panel VECM granger causality method methodologies. Destek, Ballı and Manga (2016) verified feedback hypothesis in the short-run and long-run.

Kasman and Duman (2014) examined the causal relationships between CO2, GDP, ERG, TDS and UBZ for a panel of 15 countries for the period between 1992 and 2010 with panel data analysis methodology. Kasman and Duman (2014) confirmed feedback hypothesis and found bidirectional causality between CO2, ERG, GDP and TDS. 
TABLE 18

CO2-GDP-ERG-TO-URZ FOR PANEL STUDIES

\begin{tabular}{|c|c|c|c|c|c|}
\hline Author(s) & Sample & Period & Methodology & Variables & Results \\
\hline $\begin{array}{l}\text { Destek, } \\
\text { Ballı and } \\
\text { Manga } \\
(2016)\end{array}$ & $\begin{array}{l}\text { Central } \\
\text { and } \\
\text { Eastern } \\
\text { European } \\
\text { Countries } \\
\text { (CEECs) }\end{array}$ & $\begin{array}{l}1991 \text { - } \\
2011\end{array}$ & $\begin{array}{c}\text { Panel } \\
\text { Cointegration } \\
\text { Method, } \\
\text { FMOLS, } \\
\text { DOLS, Panel } \\
\text { VECM } \\
\text { Granger } \\
\text { Causality } \\
\text { Method }\end{array}$ & $\begin{array}{l}\text { CO2, GDP, } \\
\text { ERG, UBZ, } \\
\text { TDS }\end{array}$ & $\begin{array}{l}\text { 1. The EKC hypothesis holds for } \\
\text { these countries. EKC Relationship } \\
\text { is verified. } \\
\text { 2. In the short-run; } \\
\text { CO2 } \leftrightarrow \text { GDP } \\
\text { ERG } \leftrightarrow \text { GDP } \\
\text { TDS } \leftrightarrow \text { GDP } \\
\text { 3. URZ } \neq \text { CO2 } \\
\text { 4. In the long-run; } \\
\text { GDP } \leftrightarrow \text { CO2 } \\
\text { ERG } \leftrightarrow \text { GDP } \\
\text { ERG } \leftrightarrow \text { CO2 }\end{array}$ \\
\hline $\begin{array}{l}\text { Kasman } \\
\text { and Duman } \\
(2014)\end{array}$ & $\begin{array}{c}15 \\
\text { countries }\end{array}$ & $\begin{array}{c}1992- \\
2010\end{array}$ & $\begin{array}{c}\text { Panel Data } \\
\text { Analysis }\end{array}$ & $\begin{array}{c}\text { CO2, GDP, } \\
\text { ERG, TDS, } \\
\text { UBZ }\end{array}$ & $\begin{array}{l}\text { 1. The EKC Relationship is } \\
\text { verified } \\
\text { - an inverted U-shaped } \\
\text { relationship between environment } \\
\text { and income for the sampled } \\
\text { countries } \\
\text { 2. GDP } \leftrightarrow \text { CO2 } \\
\text { GDP } \leftrightarrow \text { ERG } \\
\text { GDP } \leftrightarrow \text { TDS } \\
\text { CO2 } \leftrightarrow \text { ERG } \\
\text { CO2 } \leftrightarrow \text { TDS } \\
\text { ERG } \leftrightarrow \text { TDS }\end{array}$ \\
\hline
\end{tabular}

Saboori, Sulaiman and Mohd (2016) investigated the long-run and short-run relationships between CO2, GDP, ERG and TDS in Malaysia for the period between 1980 and 2008 with ARDL methodology. Saboori, Sulaiman and Mohd (2016) found that ERG and UBZ had positive impact on CO2 emissions in the long-run, and trade had a negative impact on $\mathrm{CO} 2$ emissions in the long-run and short-run. Their conclusions support factor endowment hypothesis (FEH).

Shahbaz et al. (2015) tested EKC hypothesis and the causal relationships between CO2, GDP, ERG, TDS and UBZ in Portugal for the period between 1971 and 2008 with ARDL and granger causality test methodologies. Shahbaz et al. (2015) found that variables were cointegrated, there was unidirectional causality running from GDP to $\mathrm{CO} 2$ in the long-run and TDS had a positive impact on $\mathrm{CO} 2$ emissions in the long-run. Shahbaz et al. (2015) suggested that authorities should carry out policies compatible with Kyoto Protocol in order to reduce $\mathrm{CO} 2$ emissions. 
TABLE 19

CO2-GDP-ERG-TDS-UBZ FOR SINGLE-COUNTRY STUDIES

\begin{tabular}{|c|c|c|c|c|c|}
\hline Author(s) & Sample & Period & Methodology & Variables & Results \\
\hline $\begin{array}{c}\text { Saboori, } \\
\text { Sulaiman } \\
\text { and Mohd } \\
(2016)\end{array}$ & Malaysia & $\begin{array}{c}1980- \\
2008\end{array}$ & $\begin{array}{c}\text { ARDL } \\
\text { Methodology }\end{array}$ & $\begin{array}{c}\text { CO2, GDP, } \\
\text { ERG, TDS, } \\
\text { UBZ }\end{array}$ & $\begin{array}{l}\text { 1. The EKC Relationship is verified } \\
\text { in the long-run. } \\
\text { 2. ERG and UBZ have positive } \\
\text { effects on CO2 emissions in the long } \\
\text { run. } \\
\text { 3. Trade has a negative effect on } \\
\text { CO2 emissions in both short and } \\
\text { long runs. Supports the FEH } \\
\text { (Factor Endowment Hypothesis). }\end{array}$ \\
\hline $\begin{array}{l}\text { Shahbaz et } \\
\text { al. (2015) }\end{array}$ & Portugal & $\begin{array}{c}1971- \\
2008\end{array}$ & $\begin{array}{c}\text { ARDL \& } \\
\text { Granger } \\
\text { Causality Test }\end{array}$ & $\begin{array}{c}\text { CO2, GDP, } \\
\text { ERG, TDS, } \\
\text { UBZ }\end{array}$ & $\begin{array}{l}\text { 1. Long run relationship between } \\
\text { ERG, GDP, TDS, UBZ and CO2. } \\
\text { 2. The EKC hypothesis tested and } \\
\text { confirmed in both short-run and } \\
\text { long-run. } \\
\text { 3. In the long-run; } \\
\text { GDP } \rightarrow \mathrm{CO2} \\
\text { 4. An increase in ERG and UBZ } \\
\text { leads to an increase in CO2 in the } \\
\text { short-run and long-run. } \\
\text { 5. TDS has positive impact on CO2 } \\
\text { in the long run. Increase in } \\
\text { international trade leads to increase } \\
\text { in CO2. } \\
\text { 6. Authorities in Portugal should } \\
\text { clarify the policies to comply with } \\
\text { Kyoto Protocol in order to reduce } \\
\text { CO2 emissions. }\end{array}$ \\
\hline
\end{tabular}

CO2-GDP-ERG-PLT

Alama et al. (2016) tested the EKC hypothesis for Brazil, China, India and Indonesia for the period between 1970 and 2012 with and verified for Brazil and Indonesia the long-run and short-run and for China in the long-run.

TABLE 20

CO2-GDP-ERG-PLT FOR MULTI-COUNTRY STUDIES

\begin{tabular}{|c|c|c|c|c|l|}
\hline Author(s) & Sample & Period & Methodology & Variables & \multicolumn{1}{c|}{ Results } \\
\hline & $\begin{array}{c}\text { Brazil, } \\
\text { Alama et } \\
\text { China, (2016) }\end{array}$ & $\begin{array}{c}\text { India and } \\
\text { Indonesia }\end{array}$ & $\begin{array}{c}\text { ARDL, VECM, } \\
\text { Gregory- } \\
\text { Hansen } \\
\text { cointegration } \\
\text { approach }\end{array}$ & $\begin{array}{l}\text { CO2, GDP, } \\
\text { ERG, PLT }\end{array}$ & $\begin{array}{l}\text { Indonesia in both long and short } \\
\text { Ind } \\
\text { run. EKC is verified for China only } \\
\text { in long-run. } \\
\text { 3. EKC is not verified for India. }\end{array}$ \\
\hline
\end{tabular}

Zoundi (2017) investigated the impacts of ERG on CO2 emissions in the long-run and short-run for a panel of 25 countries for the period between 1980 and 2012 with panel cointegration approach and robustness tests methodologies. Zoundi (2017) found that CO2, GDP, ERG and PLT were cointegrated, renewable energy had a negative impact on $\mathrm{CO} 2$ in the short-run and increasing impact in the long-run, but 
primary energy consumption exceeds the negative effect of renewable energy by increasing $\mathrm{CO} 2$ emissions. Zoundi (2017) suggested that authorities should invest more in renewable energy.

TABLE 21

CO2-GDP-ERG-PLT FOR PANEL STUDIES

\begin{tabular}{|c|c|c|c|c|c|}
\hline Author(s) & Sample & Period & Methodology & Variables & Results \\
\hline $\begin{array}{c}\text { Zoundi } \\
\text { (2017) }\end{array}$ & $\begin{array}{c}25 \\
\text { countries }\end{array}$ & $\begin{array}{c}1980- \\
2012\end{array}$ & $\begin{array}{c}\text { Panel } \\
\text { Cointegration } \\
\text { Approach and } \\
\text { Robustness tests }\end{array}$ & $\begin{array}{c}\text { CO2, GDP, ERG } \\
\text { (Primary } \\
\text { Energy } \\
\text { Consumption \& } \\
\text { Renewable } \\
\text { Energy } \\
\text { Consumption), } \\
\text { PLT }\end{array}$ & $\begin{array}{l}\text { 1. The EKC Relationship is } \\
\text { not verified. Tests and Does } \\
\text { not Confirm the existence of } \\
\text { an environmental Kuznets } \\
\text { curve. } \\
\text { 2. Variables are cointegrated } \\
\text { and there is a long-run } \\
\text { relationship between } \\
\text { variables. } \\
\text { 3. Renewable energy, with a } \\
\text { negative effect on CO2 } \\
\text { emissions, and increasing } \\
\text { impact in the long run but } \\
\text { outweighted by the effect of } \\
\text { primary energy consumption. } \\
\text { More efforts should be done } \\
\text { by authorities to spread } \\
\text { renewable energy across } \\
\text { Africa. }\end{array}$ \\
\hline
\end{tabular}

\section{CO2-GDP-ERG With Many Explanatory Variables}

Iwata, Okada and Samreth (2012) tested EKC hypothesis and examined the impact of nuclear energy on CO2 emissions for 11 OECD countries with ARDL methodology. They found that ERG had a positive impact on $\mathrm{CO} 2$ in most of 11 OECD countries, trade had an insignificant impact on CO2 and nuclear energy did not have a significant negative impact on $\mathrm{CO} 2$ in most of 11 OECD countries.

TABLE 22

CO2-GDP-ERG WITH MANY EXPLANATORY VARIABLES FOR MULTI-COUNTRY STUDIES

\begin{tabular}{|c|c|c|c|c|c|}
\hline Author(s) & Sample & Period & Methodology & Variables & Results \\
\hline $\begin{array}{c}\text { Iwata, } \\
\text { Okada and } \\
\text { Samreth } \\
(\mathbf{2 0 1 2})\end{array}$ & $\begin{array}{l}11 \text { OECD } \\
\text { Countries }\end{array}$ & $\begin{array}{c}\text { Country } \\
\text { Based }\end{array}$ & ARDL & $\begin{array}{c}\text { CO2, GDP, } \\
\text { ERG, TDS, } \\
\text { ES }\end{array}$ & $\begin{array}{l}\text { 1. Does not support the EKC } \\
\text { hypothesis for } 11 \text { OECD countries. } \\
\text { 2. In most countries, energy } \\
\text { consumption has a positive impact } \\
\text { on CO2 emissions. } \\
\text { 3. The impact of trade is not } \\
\text { statistically significant on } \mathrm{CO} 2 \\
\text { emissions. } \\
\text { 4. In most countries, nuclear } \\
\text { energy do not reduce } \mathrm{CO} 2 \\
\text { significantly. }\end{array}$ \\
\hline
\end{tabular}

Can \& Gozgor (2016) tested EKC hypothesis in France for the period between 1964 and 2011 with cointegration test of maki, DOLS, ECM, granger causality test \& block exogeneity wald test methodologies. 
Can \& Gozgor (2016) found that energy consumption had a positive impact on CO2 in the long-run and GDP suppressed CO2 in the long-run.

Munir and Khan (2014) examined the impact of ERG on CO2 in Pakistan for the period between 1980 and 2010 with johansen cointegration approach and VECM methodologies. Munir and Khan (2014) found that TDS, IA, GDP, ITT, PLT and MET had a positive impact on CO2 in the long-run and ERG, FCT and MIT had a negative impact on $\mathrm{CO} 2$ in the long-run.

Ahmed and Long (2013) examined the relationships between CO2, GDP, ERG, TDS and PLT in Pakistan for the period between 1971 and 2008 with cointegration analysis with ARDL methodology. Ahmed and Long (2013) confirmed EKC hypothesis between CO2, GDP, ERG, TDS and PLT.

Farhani and Ozturk (2015) studied the causal relationships between CO2, GDP, ERG, FCT, TDS and UBZ in Tunisia for the period between 1971 and 2012 with ARDL, ECM and granger causality methodologies. Farhani and Ozturk (2015) found that there were unidirectional causality running from GDP, ERG, FCT, TDS and UBZ to CO2 and unidirectional causality running from CO2, GDP, ERG, TDS and UBZ to FCT in the long-run. Farhani and Ozturk (2015) also found that there were unidirectional causality running from $\mathrm{CO} 2$, GDP, ERG and TDS to FCT, unidirectional causality running from GDP, ERG and UBZ to $\mathrm{CO} 2$, and unidirectional causality running from $\mathrm{CO} 2$, GDP and ERB to TDS in the longrun.

For panel studies, Omri (2013) and Dogan, Seker and Bulbul (2015) confirmed feedback hypothesis for 14 MENA countries and OECD countries respectively.

TABLE 23

CO2-GDP-ERG WITH MANY EXPLANATORY VARIABLES FOR PANEL STUDIES

\begin{tabular}{|c|c|c|c|c|c|}
\hline Author(s) & Sample & Period & Methodology & Variables & Results \\
\hline $\begin{array}{l}\text { Omri } \\
(\mathbf{2 0 1 3})\end{array}$ & $\begin{array}{l}14 \text { MENA } \\
\text { Countries }\end{array}$ & $\begin{array}{c}1990- \\
2011\end{array}$ & $\begin{array}{c}\text { Cobb-Douglas } \\
\text { production } \\
\text { function, Panel } \\
\text { GMM Method } \\
\text { (Generalized } \\
\text { Method of } \\
\text { Moments), Panel } \\
\text { Data Analysis, two- } \\
\text { stage least squares } \\
\text { (2SLS), three stages } \\
\text { least squares } \\
\text { (3SLS), } \\
\text { simultaneous- } \\
\text { equation models } \\
\end{array}$ & $\begin{array}{c}\text { CO2, GDP, } \\
\text { ERG, TDS, } \\
\text { FCT, UBZ, } \\
\text { PLT, CST } \\
\text { (Capital } \\
\text { Stock), EML }\end{array}$ & $\begin{array}{l}\text { 1. ERG } \leftrightarrow \text { GDP } \\
\text { 2. ERG } \rightarrow \mathrm{CO2}\end{array}$ \\
\hline $\begin{array}{l}\text { Dogan, } \\
\text { Seker and } \\
\text { Bulbul } \\
(\mathbf{2 0 1 5 )}\end{array}$ & $\begin{array}{c}\text { OECD } \\
\text { Countries }\end{array}$ & $\begin{array}{c}1995- \\
2010\end{array}$ & $\begin{array}{c}\text { The Lagrange } \\
\text { multiplier } \\
\text { bootstrap panel } \\
\text { cointegration, } \\
\text { DOLS, } \\
\text { Dumitrescu-Hurlin } \\
\text { Panel Granger } \\
\text { Causality Test }\end{array}$ & $\begin{array}{l}\text { CO2, GDP, } \\
\text { GDP2, ERG, } \\
\text { TDS, TT }\end{array}$ & $\begin{array}{l}\text { 1. The EKC hypothesis is } \\
\text { not verified as the sign of } \\
\text { coefficients on GDP and } \\
\text { GDP2 is negative and } \\
\text { positive, respectively. } \\
\text { 2. The existence of a long- } \\
\text { run relationship between } \\
\text { the analysed variables. } \\
\text { They move together in the } \\
\text { long-run. } \\
\text { 3. GDP } \leftrightarrow \text { CO2 } \\
\text { ERG } \leftrightarrow \text { CO2 } \\
\text { TT } \rightarrow \text { CO2 } \\
\text { TDS } \rightarrow \text { CO2 } \\
\text { GDP } \leftrightarrow \text { ERG }\end{array}$ \\
\hline
\end{tabular}




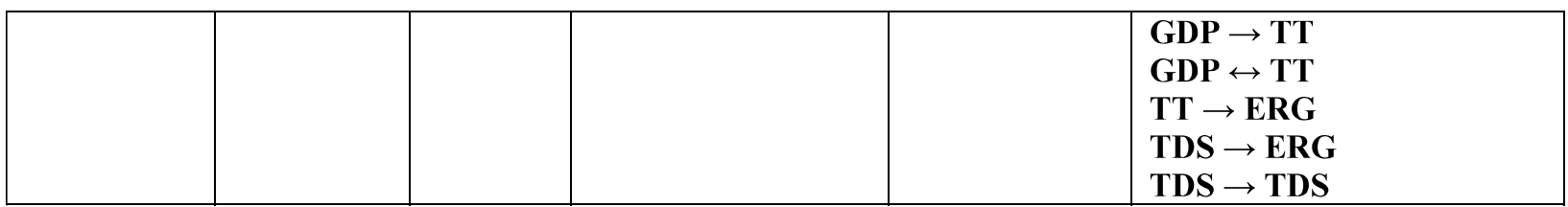

For single-country studies, Dogan and Turkekul (2016) confirmed conservation hypothesis for USA in the long-run and short-run. Ozturk and Acaravci (2016) verified growth hypothesis for Malta and Alkhathlan, Alam and Javid (2012) confirmed neutrality hypothesis for Saudi Arabia.

TABLE 24

CO2-GDP-ERG WITH MANY EXPLANATORY VARIABLES FOR SINGLE-COUNTRY STUDIES

\begin{tabular}{|c|c|c|c|c|c|}
\hline Author(s) & Sample & Period & Methodology & Variables & Results \\
\hline $\begin{array}{c}\text { Ozturk and } \\
\text { Acaravci } \\
\text { (2016) }\end{array}$ & $\begin{array}{c}\text { Cyprus, } \\
\text { Malta }\end{array}$ & $\begin{array}{c}1980- \\
2006\end{array}$ & $\begin{array}{l}\text { ARDL and } \\
\text { Error } \\
\text { correction- } \\
\text { based Granger } \\
\text { Causality } \\
\text { Models }\end{array}$ & $\begin{array}{l}\text { CO2, } \\
\text { GDP, } \\
\text { ERG, } \\
\text { TDS, } \\
\text { EML }\end{array}$ & $\begin{array}{l}\text { 1. Cointegation between variables } \\
\text { only for Malta. No cointegration } \\
\text { for Cyprus. } \\
2 . \text { Malta; } \\
\text { CO2 } \rightarrow \text { GDP } \\
\text { ERG } \rightarrow \text { GDP } \\
\text { TDS } \rightarrow \text { GDP } \\
\text { EML } \rightarrow \text { GDP }\end{array}$ \\
\hline $\begin{array}{l}\text { Can \& } \\
\text { Gozgor } \\
(\mathbf{2 0 1 6 )}\end{array}$ & France & $\begin{array}{c}1964- \\
2011\end{array}$ & $\begin{array}{c}\text { Cointegration } \\
\text { Test of Maki, } \\
\text { DOLS, ECM, } \\
\text { Granger } \\
\text { Causality Test } \\
\text { \& Block } \\
\text { Exogeneity } \\
\text { Wald Test }\end{array}$ & $\begin{array}{c}\text { CO2, } \\
\text { GDP, } \\
\text { ERG, ETS }\end{array}$ & $\begin{array}{l}\text { 1. The EKC hypothesis tested and } \\
\text { confirmed for France. (There is an } \\
\text { inverted U relationship between } \\
\text { income and CO2 emissions in } \\
\text { France) The EKC Relationship is } \\
\text { verified in France both in short- } \\
\text { run and long-run. } \\
\text { 2. Positive impact of ERG on CO2 } \\
\text { emissions is also observed in the } \\
\text { long run. (relationship) } \\
\text { 3. A higher economic complexity } \\
\text { suppresses CO2 emissions in the } \\
\text { long run. (relationship) }\end{array}$ \\
\hline $\begin{array}{l}\text { Munir and } \\
\text { Khan (2014) }\end{array}$ & Pakistan & $\begin{array}{c}1980- \\
2010\end{array}$ & $\begin{array}{c}\text { Johansen } \\
\text { Cointegration } \\
\text { Approach and } \\
\text { VECM }\end{array}$ & $\begin{array}{l}\text { CO2, } \\
\text { GDP, } \\
\text { ERG, IA, } \\
\text { FCT, } \\
\text { TDS, PLT, } \\
\text { MET, } \\
\text { MIT, ITT }\end{array}$ & $\begin{array}{l}\text { 1. The EKC Relationship is } \\
\text { verified. } \\
\text { 2. ERG negatively affects } \mathrm{CO} 2 \text { in } \\
\text { the long-run. } \\
\text { 3. IA positively affects } \mathrm{CO} 2 \text { in the } \\
\text { long-run. } \\
\text { 4. TDS positively affects } \mathrm{CO} 2 \text { in } \\
\text { the long-run. } \\
\text { 5. FCT reduces } \mathrm{CO} 2 \text { in the long- } \\
\text { run. } \\
\text { 6. GDP, ITT, PLT and MET } \\
\text { positively affect ERG in the long- } \\
\text { run. } \\
\text { 7. MIT negatively affect energy } \\
\text { consumption in the long-run. }\end{array}$ \\
\hline
\end{tabular}




\begin{tabular}{|c|c|c|c|c|c|}
\hline $\begin{array}{l}\text { Ahmed and } \\
\text { Long (2013) }\end{array}$ & Pakistan & $\begin{array}{c}1971- \\
2008\end{array}$ & ARDL & $\begin{array}{c}\text { CO2, } \\
\text { GDP, } \\
\text { ERG, } \\
\text { TDS, PLT }\end{array}$ & $\begin{array}{l}\text { 1. Do not support EKC in a short- } \\
\text { run, whereas the long-run inverted } \\
\text { U shaped hypothesis was } \\
\text { confirmed between carbon } \\
\text { emission and growth, ERG, TDS } \\
\text { and PLT. }\end{array}$ \\
\hline $\begin{array}{l}\text { Alkhathlan, } \\
\text { Alam and } \\
\text { Javid (2012) }\end{array}$ & $\begin{array}{c}\text { Saudi } \\
\text { Arabia }\end{array}$ & $\begin{array}{c}1980- \\
2008\end{array}$ & $\begin{array}{l}\text { ARDL, VECM, } \\
\text { ECM based } \\
\text { Granger } \\
\text { Causality test }\end{array}$ & $\begin{array}{l}\text { CO2, } \\
\text { GDP, } \\
\text { ERG, } \\
\text { EML }\end{array}$ & $\begin{array}{l}\text { 1. The EKC hypothesis does not } \\
\text { hold in the case of Saudi Arabia. } \\
\text { 2. CO2 emissions, ERG, and EML } \\
\text { have positive and significant } \\
\text { impacts on GDP in the long run. } \\
\text { 3. In the short-run; } \\
\text { Neither CO2 emissions nor ERG } \\
\text { cause GDP. } \\
\text { EML } \rightarrow \text { GDP } \\
\text { 4. A long run relationship between } \\
\text { economic growth, ERG and the } \\
\text { EML exist in Saudi Arabia. } \\
\text { 5. Neutrality hypothesis holds. No } \\
\text { causal relationship exist between } \\
\text { economic growth and ERG. } \\
\text { 6. ERG } \leftrightarrow \text { EML }\end{array}$ \\
\hline $\begin{array}{c}\text { Farhani and } \\
\text { Ozturk } \\
\text { (2015) }\end{array}$ & Tunisia & $\begin{array}{c}1971- \\
2012\end{array}$ & $\begin{array}{c}\text { ARDL, ECM, } \\
\text { Granger } \\
\text { Causality } \\
\text { Method }\end{array}$ & $\begin{array}{l}\text { CO2, } \\
\text { GDP, } \\
\text { ERG, } \\
\text { FCT, } \\
\text { TDS, UBZ }\end{array}$ & $\begin{array}{l}\text { 1. The EKC relationship is not } \\
\text { verified. A positive monotonic } \\
\text { relationship between real GDP and } \\
\text { CO2 emissions. } \\
2 . \text { In the long-run; } \\
\text { GDP } \rightarrow \text { CO2 } \\
\text { ERG } \rightarrow \text { CO2 } \\
\text { FCT } \rightarrow \text { CO2 } \\
\text { TDS } \rightarrow \text { CO2 } \\
\text { UBZ } \rightarrow \text { CO2 } \\
\text { CO2 } \rightarrow \text { FCT } \\
\text { GDP } \rightarrow \text { FCT } \\
\text { ERG } \rightarrow \text { FCT } \\
\text { TDS } \rightarrow \text { FCT } \\
\text { UBZ } \rightarrow \text { FCT } \\
\text { 3. In the short-run; } \\
\text { GDP } \rightarrow \text { CO2 } \\
\text { ERG } \rightarrow \text { CO2 } \\
\text { UBZ } \rightarrow \text { CO2 } \\
\text { CO2 } \rightarrow \text { FCT } \\
\text { GDP } \rightarrow \text { FCT } \\
\text { ERG } \rightarrow \text { FCT } \\
\text { TDS } \rightarrow \text { FCT } \\
\text { CO2 } \rightarrow \text { TDS } \\
\text { GDP } \rightarrow \text { TDS } \\
\text { ERG } \rightarrow \text { TDS } \\
\text { UBZ } \rightarrow \text { TDS } \\
4 . A \text { long-run relationship between } \\
\text { variables. }\end{array}$ \\
\hline
\end{tabular}




\begin{tabular}{|c|c|c|c|c|c|}
\hline $\begin{array}{c}\text { Katırcioglu } \\
\text { (2017) }\end{array}$ & Turkey & $\begin{array}{c}1960- \\
2010\end{array}$ & $\begin{array}{l}\text { DOLS, Granger } \\
\text { Causality Test, } \\
\text { Maki } \\
\text { cointegration } \\
\text { test, ECM }\end{array}$ & $\begin{array}{c}\text { CO2, } \\
\text { GDP, } \\
\text { ERG, OIC } \\
\text { (Oil Price) }\end{array}$ & $\begin{array}{l}\text { 1. Does not Confirm the oil- } \\
\text { induced EKC hypothesis in the } \\
\text { case of Turkey. Supports the EKC } \\
\text { hypothesis for Turkey. } \\
\text { 2. CO2, GDP, OIC and ERG } \\
\text { Turkey are in long term } \\
\text { equilibrium relationship. } \\
\text { 3. In the short-run; } \\
\text { ERG } \rightarrow \text { OIC }\end{array}$ \\
\hline $\begin{array}{c}\text { Dogan and } \\
\text { Turkekul } \\
\text { (2016) }\end{array}$ & USA & $\begin{array}{c}1960- \\
2010\end{array}$ & $\begin{array}{c}\text { ARDL, VECM } \\
\text { Granger } \\
\text { Causality Test }\end{array}$ & $\begin{array}{c}\text { CO2, } \\
\text { GDP, } \\
\text { ERG, } \\
\text { GDP2, } \\
\text { TDS, } \\
\text { UBZ, FCT }\end{array}$ & 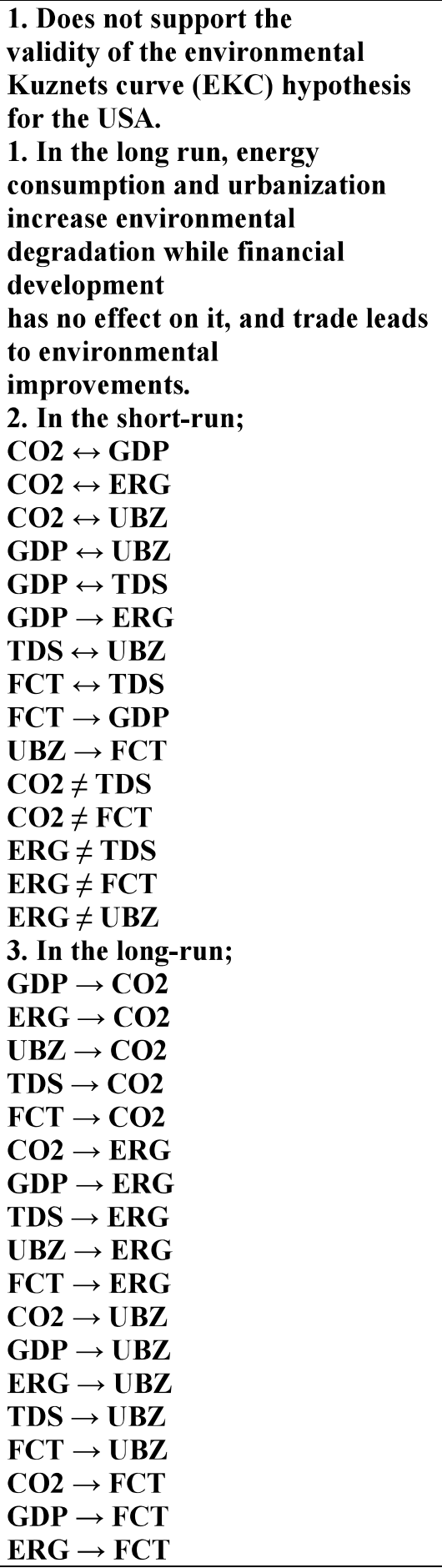 \\
\hline
\end{tabular}




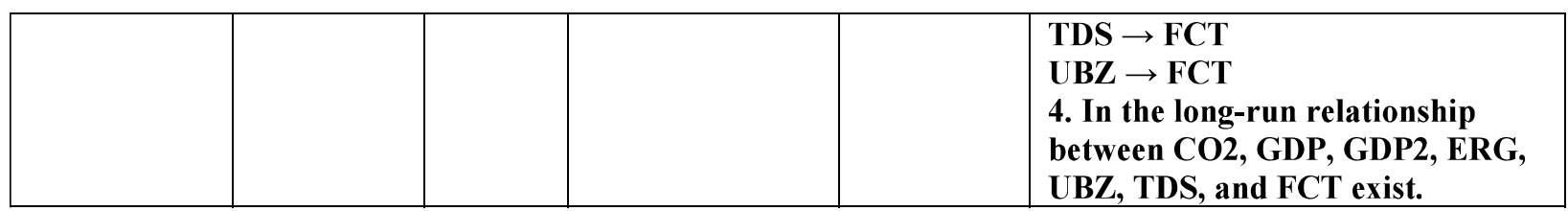

CO2-GDP-ERG-FIND

For panel studies, Linh and Lin (2015) examined the causal relationships between CO2, GDP, ERG and FIDN for a panel of 12 most populous Asian countries for the period between 1980 and 2010 with johansen cointegration test, panel granger causality test, VECM and OLS methodologies. Linh and Lin (2015) confirmed conservation hypothesis in the short-run and feedback hypothesis in the long-run. Kim (2015) studied the causal relationships between CO2, GDP, ERG and FIDN for a panel of Asian newly industrialized countries, which were Republic of Korea, Singapore and Taiwan, for the period between 1971 and 2011 with VECM and panel granger causality test methodologies. Kim (2015) found that there were unidirectional causality running from GDP, inward FIDN and outward FIDN to CO2 and unidirectional causality from CO2 to ERG in the short-run. Kim (2015) also found that FIDN had a significant impact on $\mathrm{CO} 2$ for panel countries, and there were unidirectional causality running from GDP, ERG, inward FIDN and outward FIDN to CO2 in the long-run.

Pao and Tsai (2011) studied the impact of GDP and FIDN on CO2 for panel countries of Brazil, Russia, India and China for the period 1980 and 2007 (for Russia, 1992 - 2007) with panel cointegration framework and panel causality test methodologies. Pao and Tsai (2011) found that there were unidirectional causality running from ERG to $\mathrm{CO} 2$ and from GDP to FIDN in the short-run. Unidirectional causality running from $\mathrm{CO} 2$ to FIDN and GDP in the short-run, and unidirectional causality running from ERG to FIDN and GDP in the short-run were confirmed. Bidirectional causality between CO2 and FIDN was verified in the study. Chen and Huang (2013) investigated the causal relationships between CO2, GDP, ERG, FIDN and UBZ for panel countries of Next Eleven Countries for the period between 1981 and 2009 with Cointegration in heterogeneous panels and panel causality test methodologies. Chen and Huang (2013) found that there were unidirectional causality running from FIDN and GDP to UBZ, unidirectional causality running from CO2 and UBZ to electric power consumption, and unidirectional causality running from $\mathrm{CO} 2$ and ERG to GDP.

TABLE 25

CO2-GDP-ERG-FIDN FOR PANEL STUDIES

\begin{tabular}{|c|c|c|c|c|c|}
\hline Author(s) & Sample & Period & Methodology & Variables & Results \\
\hline $\begin{array}{c}\text { Linh and } \\
\text { Lin (2015) }\end{array}$ & $\begin{array}{c}12 \text { most } \\
\text { populous } \\
\text { Asian } \\
\text { countries } \\
\text { (MPCA12) }\end{array}$ & $\begin{array}{c}1980- \\
2010\end{array}$ & $\begin{array}{c}\text { Johansen } \\
\text { Cointegration } \\
\text { Test, Panel } \\
\text { Granger } \\
\text { Causality Test, } \\
\text { VECM, OLS }\end{array}$ & $\begin{array}{l}\text { CO2, GDP, } \\
\text { ERG, FIDN }\end{array}$ & $\begin{array}{l}\text { 1. Supports the EKC. Japan's } \\
\text { EKC is not different from } 12 \\
\text { most populous Asian countries } \\
\text { '(MPCA12) EKC. } \\
2 \text {. In the short-run; } \\
\text { CO2 } \leftrightarrow \text { ERG } \\
\text { GDP } \leftrightarrow \text { FIDN (inflow) } \\
\text { GDP } \rightarrow \text { CO2 } \\
\text { GDP } \rightarrow \text { ERG } \\
\text { CO2 } \neq \text { FIDN } \\
\text { FIDN } \neq \text { ERG } \\
\text { GDP (Japan) } \neq \text { CO2 (MPCA12) } \\
\text { GDP (Japan) } \leftrightarrow \text { FIDN (inflow) } \\
(\text { MPCA12) } \\
\text { 3. In the long-run; } \\
\text { ERG } \leftrightarrow \text { GDP } \\
\text { FIDN } \leftrightarrow \text { GDP } \\
\text { CO2 } \rightarrow \text { ERG }\end{array}$ \\
\hline
\end{tabular}




\begin{tabular}{|c|c|c|c|c|c|}
\hline & & & & & $\begin{array}{l}\text { CO2 } \rightarrow \text { GDP } \\
\text { CO2 } \rightarrow \text { FIDN } \\
\text { FIDN } \rightarrow \text { ERg } \\
\text { CO2 }(\text { MPCA12) } \rightarrow \text { CO2 (Japan) } \\
\text { FIDN }(\text { MPCA12) } \rightarrow \text { GDP (Japan) } \\
\text { ERG (MPCA12) } \leftrightarrow \text { GDP (Japan) } \\
\text { GDP }(\text { MPCA12) } \leftrightarrow \text { GDP (Japan) }\end{array}$ \\
\hline Kim (2015) & ANICs & $\begin{array}{c}1971 \text { - } \\
2011\end{array}$ & $\begin{array}{c}\text { VECM \& } \\
\text { Panel Granger } \\
\text { Causality Test }\end{array}$ & $\begin{array}{l}\text { CO2, GDP, } \\
\text { ERG, FIDN }\end{array}$ & $\begin{array}{l}\text { 1. The EKC Relationship is } \\
\text { verified. } \\
\text { 2. Long run cointegrated } \\
\text { relationship between CO2, ERG, } \\
\text { GDP and FIDN. } \\
\text { 3. In the short-run; } \\
\text { GDP } \rightarrow \mathrm{CO2} \\
\text { Inward FIDN } \rightarrow \mathrm{CO2} \\
\text { Outward FIDN } \rightarrow \mathrm{CO2} \\
\mathrm{CO2} \rightarrow \text { ERG } \\
4 . \text { In the long-run; } \\
\text { GDP } \rightarrow \mathrm{CO} 2 \\
\text { ERG } \rightarrow \mathrm{CO} 2 \\
\text { Inward FIDN } \rightarrow \mathrm{CO} 2 \\
\text { Outward FIDN } \rightarrow \mathrm{CO} 2 \\
5 \text {. FIDN has a significant impact } \\
\text { on CO2 in the region. }\end{array}$ \\
\hline
\end{tabular}

For single-country studies, Ozturk and Oz (2016) investigated the relationships between CO2, GDP, ERG and FIDN in Turkey for the period between 1974 and 2011 with cointegration method and granger causality analysis methodologies. Ozturk and Oz (2016) confirmed growth hypothesis in Turkey. Ozturk and $\mathrm{Oz}$ (2016) found that there were bidirectional causalities between CO2, FIDN and GDP in the shortrun and long-run. Ozturk and $\mathrm{Oz}$ (2016) also found that there was bidirectional causality between FIDN and ERG in the long-run and short-run.

TABLE 25 CONTINUED

\begin{tabular}{|c|c|c|c|c|c|}
\hline Author(s) & Sample & Period & Methodology & Variables & Results \\
\hline $\begin{array}{l}\text { Pao and } \\
\text { Tsai (2011) }\end{array}$ & $\begin{array}{c}\text { Brazil, } \\
\text { Russia, } \\
\text { India and } \\
\text { China }\end{array}$ & $\begin{array}{c}1980- \\
2007 \\
\text { (Russia } \\
-1992- \\
2007)\end{array}$ & $\begin{array}{c}\text { Panel } \\
\text { Cointegration } \\
\text { Framework \& } \\
\text { Panel Causality } \\
\text { Test }\end{array}$ & $\begin{array}{l}\text { CO2, GDP, } \\
\text { ERG, FIDN }\end{array}$ & $\begin{array}{l}\text { 1. The EKC Relationship is } \\
\text { verified. Supportive of the } \\
\text { EKC hypothesis, with } \\
\text { emissions increasing with } \\
\text { real output, stabilizing, and } \\
\text { then declining. } \\
\text { 2. Long-run equilibrium } \\
\text { relationship between } \\
\text { emissions, } \\
\text { ERG, FIDN and real output } \\
\text { for the panel BRIC } \\
\text { countries. } \\
\text { 3. In the short-run; } \\
\text { ERG } \rightarrow \text { CO2 } \\
\text { GDP } \rightarrow \text { FIDN } \\
\text { CO2 } \leftrightarrow \text { FIDN } \\
\text { CO2 } \leftrightarrow \text { GDP } \\
\text { ERG } \leftrightarrow \text { FIDN } \\
\text { ERG } \leftrightarrow \text { GDP }\end{array}$ \\
\hline
\end{tabular}




\begin{tabular}{|c|c|c|c|c|c|}
\hline & & & & & $\begin{array}{l}\text { 4. In the long-run; } \\
\mathrm{CO} 2 \leftrightarrow \text { FIDN }\end{array}$ \\
\hline $\begin{array}{c}\text { Chen and } \\
\text { Huang } \\
\text { (2013) }\end{array}$ & $\begin{array}{c}\text { Next } \\
\text { Eleven } \\
\text { Countries }\end{array}$ & $\begin{array}{c}1981- \\
2009\end{array}$ & $\begin{array}{c}\text { Cointegration in } \\
\text { Heterogeneous } \\
\text { Panels and } \\
\text { Panel Causality } \\
\text { Test }\end{array}$ & $\begin{array}{c}\text { CO2, GDP, } \\
\text { ERG (Energy } \\
\text { Use, Electric } \\
\text { Power } \\
\text { Consumption), } \\
\text { UBZ, FIDN }\end{array}$ & $\begin{array}{l}\text { 1. In the short -run; } \\
\text { CO2 } \leftrightarrow \text { Electric Power } \\
\text { Consumption } \\
\text { CO2 } \rightarrow \text { GDP } \\
\text { URZ } \rightarrow \text { Electric Power } \\
\text { Consumption } \\
\text { Energy Use } \rightarrow \text { GDP } \\
\text { FIDN } \rightarrow \text { UBZ } \\
\text { GDP } \rightarrow \text { UBZ } \\
2 . \text { Positive long-run } \\
\text { relationship among CO2 } \\
\text { emissions, Electric power } \\
\text { consumption, Energy use } \\
\text { and GDP. }\end{array}$ \\
\hline
\end{tabular}

TABLE 26

CO2-GDP-ERG-FIDN FOR SINGLE-COUNTRY STUDIES

\begin{tabular}{|c|c|c|c|c|c|}
\hline Author(s) & Sample & Period & Methodology & Variables & Results \\
\hline $\begin{array}{l}\text { Öztürk and } \\
\text { Öz (2016) }\end{array}$ & Turkey & $\begin{array}{c}1974- \\
2011\end{array}$ & $\begin{array}{c}\text { Cointegration } \\
\text { Method and } \\
\text { Granger } \\
\text { Causality } \\
\text { Analysis }\end{array}$ & $\begin{array}{l}\text { CO2, GDP, } \\
\text { ERG, FIDN }\end{array}$ & $\begin{array}{l}\text { 1. The EKC Relationship is } \\
\text { verified in the long-term and } \\
\text { short-term. } \\
\text { 2. Long term relationship between } \\
\text { the variables. } \\
\text { 3. In the short-run; } \\
\text { CO2 } \leftrightarrow \text { FIDN } \\
\text { CO2 } \leftrightarrow \text { GDP } \\
\text { CO2 } \rightarrow \text { ERG } \\
\text { ERG } \rightarrow \text { GDP } \\
\text { GDP } \leftrightarrow \text { FIDN } \\
\text { ERG } \leftrightarrow \text { FIDN } \\
4 . \text { In the long-term; } \\
\text { CO2 } \leftrightarrow \text { GDP } \\
\text { CO2 } \leftrightarrow \text { FIDN } \\
\text { GDP } \leftrightarrow \text { FIDN } \\
\text { FIDN } \leftrightarrow \text { ERG } \\
5 . \text { ERG } \rightarrow \text { GDP; Growth } \\
\text { hypothesis holds }\end{array}$ \\
\hline
\end{tabular}

\section{CO2-GDP-ERG-TDS}

Akın (2014) studied the impact of ERG, TDS and GDP on CO2 for a panel of 85 countries for the period between 1990 and 2011 with pedroni, kao and johansen fisher panel co-integration tests, FMOLS \& DOLS, panel granger causality test and ECM methodologies. Akın (2014) confirmed conservation hypothesis in the long-run and short-run, and found that TDS had a negative impact $\mathrm{CO} 2$ in the short-run and decreased CO2 after a threshold level. Mallick and Tandi (2015) confirmed that CO2, GDP, ERG and TDS were cointegrated for a panel of selected SAARC countries which were Bangladesh, India, Nepal, Pakistan, and Sri Lanka. 
TABLE 27

CO2-GDP-ERG-TDS FOR PANEL STUDIES

\begin{tabular}{|c|c|c|c|c|c|}
\hline Author(s) & Sample & Period & Methodology & Variables & Results \\
\hline Akın (2014) & $\begin{array}{c}85 \\
\text { Countries }\end{array}$ & $\begin{array}{c}1990- \\
2011\end{array}$ & $\begin{array}{c}\text { Pedroni, Kao } \\
\text { and Johansen } \\
\text { Fisher panel co- } \\
\text { integration } \\
\text { tests, FMOLS } \\
\text { \& DOLS, Panel } \\
\text { Granger } \\
\text { Causality Test, } \\
\text { ECM }\end{array}$ & $\begin{array}{l}\text { CO2, GDP, } \\
\text { ERG, TDS, } \\
\text { TDS2 } \\
\text { (Square of } \\
\text { TDS) }\end{array}$ & $\begin{array}{l}\text { 1. In the short-run; } \\
\text { GDP } \leftrightarrow \text { TDS } \\
\text { GDP } \leftrightarrow \text { TDS2 } \\
\text { GDP } \rightarrow \text { CO2 } \\
\text { GDP } \rightarrow \text { ERG } \\
\text { CO2 } \rightarrow \text { TDS } \\
\text { CO2 } \rightarrow \text { TDS2 } \\
2 . \text { Long run relationship between } \\
\text { the variables. } \\
3 . \text { In the long-run; } \\
\text { GDP } \rightarrow \text { CO2 } \\
\text { TDS } \rightarrow \text { CO2 } \\
\text { ERG } \rightarrow \text { CO2 } \\
\text { GDP } \rightarrow \text { ERG } \\
\text { TDS } \rightarrow \text { ERG } \\
\text { CO2 } \rightarrow \text { ERG } \\
\text { TDS2 } \rightarrow \text { CO2 } \\
\text { TDS } \rightarrow \text { ERG } \\
4 . \text { The increase of production and } \\
\text { ERG enhance the CO2 emission. } 5 \text {. } \\
\text { The increase of TDS affect the } \\
\text { CO2 emission positively in short } \\
\text { term, then the increase of TDS will } \\
\text { decrease the CO2 emission after a } \\
\text { threshold level. }\end{array}$ \\
\hline $\begin{array}{c}\text { Mallick } \\
\text { and Tandi } \\
\text { (2015) }\end{array}$ & $\begin{array}{c}\text { Selected } \\
\text { SAARC } \\
\text { countries } \\
\text { (Bangladesh, } \\
\text { India, } \\
\text { Nepal, } \\
\text { Pakistan, } \\
\text { and Sri } \\
\text { Lanka) }\end{array}$ & $\begin{array}{l}1972- \\
2010\end{array}$ & $\begin{array}{c}\text { Panel } \\
\text { Cointegration } \\
\text { Test \& Fully } \\
\text { Modified Least } \\
\text { Square }\end{array}$ & $\begin{array}{l}\text { CO2, GDP, } \\
\text { ERG, TDS }\end{array}$ & $\begin{array}{l}\text { 1. Long-run relationship between } \\
\text { CO2, ERG, GDP and TDS. } \\
\text { 2. The EKC Relationship is not } \\
\text { verified for Selected SAARC } \\
\text { countries in the long-run. } \\
\text { 3. In individual analysis, EKC } \\
\text { Relationship is verified for } \\
\text { Bangladesh and Sri Lanka. } \\
\text { 3. GDP leads to lower CO2. } \\
\text { Negative relationship between } \\
\text { GDP and CO2. } \\
\text { 4. Higher GDP2 leads to higher } \\
\text { CO2. Positive relationship between } \\
\text { GDP2 and CO2. }\end{array}$ \\
\hline
\end{tabular}

For single-country studies on CO2-GDP-ERG-TDS, Jalil and Mahmud (2009) found no causality between TDS and CO2, while Palamalai, Siddanth and Prakasam (2015) found unidirectional causality running from TDS to $\mathrm{CO} 2$ in the short-run and long-run.

Saboori, Sulaiman and Mohd (2012a) found that TDS had a positive significant impact on CO2 in the long-run, while Ahmed and Qazi (2014) concluded that TDS had an insignificant impact on CO2 in the long-run and Shahbaz, Lean and Shabbir (2012) concluded that TDS reduced CO2 in the long-run.

Ahmed and Qazi (2014) and Shahbaz, Lean and Shabbir (2012) found that TDS had an insignificant impact on CO2 in the short-run, while Saboori, Sulaiman and Mohd (2012) found that TDS had a negative significant impact in the short-run. 
Uddin, Bidisha and Ozturk (2016) confirmed conservation hypothesis in Sri Lanka in the long-run. Palamalai, Siddanth and Prakasam (2015) confirmed feedback hypothesis for coal consumption and electricity consumption in the long-run and conservation hypothesis for crude oil consumption and natural gas consumption in the long-run. Palamalai, Siddanth and Prakasam (2015) also confirmed conservation hypothesis for coal consumption, electricity consumption and natural gas consumption in the short-run and feedback hypothesis for crude oil consumption in the short-run.

TABLE 28

CO2-GDP-ERB-TDS FOR SINGLE-COUNTRY STUDIES

\begin{tabular}{|c|c|c|c|c|c|}
\hline Author(s) & Sample & Period & Methodology & Variables & Results \\
\hline $\begin{array}{c}\text { Jalil and } \\
\text { Mahmud } \\
\text { (2009) }\end{array}$ & China & $\begin{array}{c}1975- \\
2005\end{array}$ & ARDL & $\begin{array}{l}\text { CO2, GDP, } \\
\text { ERG, TDS }\end{array}$ & $\begin{array}{l}\text { 1. EKC is verified. Quadratic } \\
\text { relationship between income and } \\
\text { CO2 emission for the sample } \\
\text { period. } \\
\text { 2. In the long-run; } \\
\text { GDP } \rightarrow \mathrm{CO2} \\
\text { ERG } \rightarrow \mathrm{CO} 2 \\
\mathrm{TDS} \neq \mathrm{CO2}\end{array}$ \\
\hline $\begin{array}{l}\text { Palamalai, } \\
\text { Siddanth } \\
\text { and } \\
\text { Prakasam } \\
\text { (2015) }\end{array}$ & India & $\begin{array}{l}1970- \\
2012\end{array}$ & $\begin{array}{l}\text { Gregory and } \\
\text { Hansen } \\
\text { cointegration } \\
\text { test, Granger } \\
\text { causality test } \\
\text { based on } \\
\text { VECM and } \\
\text { Variance } \\
\text { Decomposition } \\
\text { Analysis }\end{array}$ & $\begin{array}{l}\text { CO2, GDP, } \\
\text { ERG (Coal, } \\
\text { Crude Oil, } \\
\text { Electricity } \\
\text { and Natural } \\
\text { Gas), TDS }\end{array}$ & $\begin{array}{l}\text { 1. In the long-run; } \\
\text { Coal consumption } \leftrightarrow \text { GDP } \\
\text { Coal consumption } \leftrightarrow \text { CO2 } \\
\text { GDP } \leftrightarrow \text { CO2 } \\
\text { GDP } \rightarrow \text { Crude Oil Consumption } \\
\text { GDP } \rightarrow \text { TDS } \\
\text { GDP } \rightarrow \text { Natural Gas Consumption } \\
\text { GDP } \rightarrow \text { TDS } \\
\text { TDS } \rightarrow \text { Coal consumption } \\
\text { TDS } \rightarrow \text { GDP } \\
\text { TDS } \rightarrow \text { CO2 } \\
\text { TDS } \rightarrow \text { Electricity Consumption } \\
\text { Crude Oil Consumption } \leftrightarrow \text { TDS } \\
\text { Electricity Consumption } \leftrightarrow \text { GDP } \\
\text { Electricity Consumption } \leftrightarrow \text { CO2 } \\
\text { Natural Gas Consumption } \leftrightarrow \text { TDS } \\
\text { 3. In the short-run; } \\
\text { GDP } \rightarrow \text { Coal consumption } \\
\text { GDP } \rightarrow \text { Electricity Consumption } \\
\text { GDP } \rightarrow \text { Natural Gas Consumption } \\
\text { CO2 } \rightarrow \text { GDP } \\
\text { CO2 } \rightarrow \text { TDS } \\
\text { TDS } \rightarrow \text { GDP } \\
\text { TDS } \rightarrow \text { CO2 } \\
\text { Crude Oil Consumption } \leftrightarrow \text { GDP } \\
\text { Crude Oil Consumption } \rightarrow \text { TDS }\end{array}$ \\
\hline
\end{tabular}

\section{STUDIES FOR THE EKC HYPOTHESIS BETWEEN 2018 AND 2020}

For selected studies for the EKC hypothesis covering the period 2018 to 2020, Sarkodie and Strezov (2018) confirmed the EKC relationship between emissions and economic growth for China and Australia. Sarkodie and Strezov did not find evidence for the EKC relationship for the USA and Ghana. Sarkodie and Strezov also analyzed the environmental sustainability curve relationship between biocapacity and growth. 
Sarkodie and Strezov confirmed the environmental sustainability curve relationship for Australia and the USA.

Dong, Sun, Jiang and Zeng (2018) confirmed the EKC hypothesis for China. Du, Liu, Lei and Huang (2018) confirmed $\mathrm{N}$-shaped relationship between emissions and growth for China. Hao, Wu, Wang and Huang (2018) confirmed N-shaped relationship between environmental degradation and growth for a panel study for China.

Shahbaz and Sinha (2019) analyzed the literature review for environmental Kuznets curve and stated that majority of the reviewed studies focused on linear relationships between income and environmental degradation.

Shahbaz and Sinha suggested that future studies should focus on nonlinear relationships for the analysis of the EKC hypothesis.

Gui, Zhao and Zhang (2019) analyzed and did not confirm waste Kuznets curve for China. Song, Zhang and Zhou (2019) confirmed the EKC hypothesis for China and the USA. Zhou, Wang and Wang (2019) confirmed the EKC hypothesis for China. He and Lin (2019) analyzed the nonlinear relationships between income and emissions for China and confirmed the EKC hypothesis for a panel study for China.

Cohen, Tovar, Loungani, Marto and Wang (2019) confirmed the EKC hypothesis for a panel study for China. Chai et al. (2019) analyzed and confirmed N-shaped relationship between coal consumption and income for China. Chai et al. (2019) analyzed coal consumption Kuznets curve in China and did not confirm. Liu and Lin (2019) confirmed N-shaped relationship between environmental degradation and economic growth.

Nie, Li, Wang and Zhang (2019) analyzed the nonlinear relationships between environmental degradation and economic growth. Nie, Li, Wang and Zhang confirmed the nonlinear relationships between environmental degradation and economic growth. Wang and $\mathrm{He}$ (2019) confirmed N-shaped Kuznets curve for China. Xie, Xu and Liu (2019) confirmed the EKC hypothesis for a panel study for China. J. Liu, Qu and Zhao (2019) confirmed the EKC hypothesis for China. Yao, Zhang and Zhang (2019) confirmed the EKC hypothesis for the relationship between renewable energy consumption and economic growth for panel study including China in the analysis.

Liang and Yang (2019) confirmed the EKC hypothesis for a panel study in China. Tan (2019) confirmed inverted $\mathrm{N}$-shaped relationship between environmental degradation and economic growth. Mele and Randazzo (2019) confirmed the long-run relationship between economic growth and environmental degradation for China. Ahmad, Du, Tian and Wang (2019) confirmed N-shaped relationship between emissions and economic growth for China. Hao, Huang and Wu (2019) confirmed the EKC hypothesis for China. Zhang, Sharp and Xu (2019) confirmed the EKC relationship between emissions and economic growth for China. Fang, Hao, Wang and Hao (2019) found inverted N-shaped relationship between emissions and economic growth for a panel study in China.

Sarkodie et al. (2020) confirmed the EKC relationship between environmental degradation and economic growth for China. M. Ahmad et al. (2020) confirmed the EKC relationship between emissions and economic growth for China. Kacprzyk and Kuchta (2020) confirmed the EKC hypothesis for a panel of 161 countries.

Purcel (2020) stated that most of the reviewed studies in the literature confirmed the cointegration between income and environmental degradation in the literature review for environmental Kuznets curve. Purcel suggested that developing and transitional economies should contribute more efforts for climate change to support developed countries.

Pincheira and Zuniga (2020) carried out a literature review for environmental Kuznets curve covering the period 2005 to 2017. Pincheira and Zuniga mainly discussed the econometric methodologies and variables used in the examination of the EKC hypothesis and suggested that future studies should focus on new econometric limitations and new environmental measurements. 


\section{CONCLUSION}

In this study, the EKC literature is analyzed for income-energy-emissions nexus for the period 2002 to 2020 for the selected studies. The analyzed literature consists many variables that are added to income, energy and emissions variables. The studies show that there is no consensus in the litereature for EKC relationship between income and emissions. Although many variables are examined in the literature, the effect of external debt on emissions and on the relationship between income and emissions is not examined in detail. We recommend that the effect of external debt on emissions and on the relationship between emissions and income with including structural breaks should be analyzed. The effect of external debt should be analyzed more for developing countries than developed countries since countries such as China and Turkey may finance their emission intense industries through external debt because of certain internal regulations. This study shows that the general tendency in the literature is to examine symmetric relationships between income and emissions. There might be hidden relationships between income and emissions which can be analyzed by non-linear relationship tests. For the country of studies to be analyzed, Australia may be studied since EKC relationship is not analyzed in detail for Australia in the literature. There are studies in the literature that used other variables instead of $\mathrm{CO} 2$ to analyze the relationship between emissions and income for the EKC relationship. We recommend that coal consumption to be used instead of $\mathrm{CO} 2$ to analyze the relationship between income and emissions for the EKC relationship. Coal consumption Kuznets curve should be analyzed for developing and developed countries since coal is one of the major pollutants to generate carbon emissions in the world. Analysis of the relationship between coal consumption and income might lead to new energy policies to reduce carbon emissions for developing and developed countries to help these countries to reach certain emission reduction targets. We also recommend that carbon emissions from residential buildings to be analyzed to investigate whether developed and developing countries will meet emission targets for emissions from residential buildings.

\section{REFERENCES}

Acaravci, A., \& Ozturk, I. (2010). On the relationship between energy consumption, CO2 emissions and economic growth in Europe. Energy, 35(12), 5412-5420. https://doi.org/10.1016/j.energy.2010.07.009

Ahmad, M., Zhao, Z-Y., Irfan, M., Mukeshimana, M. C., Rehman, A., Jabeen, G., \& Li, H. (2020). Modeling heterogeneous dynamic interactions among energy investment, SO 2 emissions and economic performance in regional China. Environmental Science and Pollution Research, 27, 2730-2744.

Ahmad, N., Du, L., Tian, X-L., \& Wang, J. (2019). Chinese growth and dilemmas: Modelling energy consumption, - CO2 emissions and growth in China. Quality \& Quantity, 53, 315-338. https://doi.org/10.1007/s11135-018-0755-0

Ahmed, K., \& Long, W. (2013). An empirical analysis of CO2 emission in Pakistan using EKC hypothesis. Journal of International Trade Law and Policy, 12(2), 188-200. https://doi.org/10.1108/JITLP-10-2012-0015

Ahmed, K., \& Qazi, A.Q. (2014). Environmental Kuznets curve for CO2 emission in Mongolia: An empirical analysis. Management of Environmental Quality: An International Journal.

Akin, C.S. (2014). The Impact of Foreign Trade, Energy Consumption and Income on CO2 Emissions. International Journal of Energy Economics and Policy, 4(3), 465-475.

Alam, M.M., Murad, M.W., Noman, A.H.M., \& Ozturk, I. (2016). Relationships among carbon emissions, economic growth, energy consumption and population growth: Testing Environmental Kuznets Curve hypothesis for Brazil, China, India and Indonesia. Ecological Indicators, 70, 466479. https://doi.org/10.1016/j.ecolind.2016.06.043

Albiman, M.M., Suleiman, N.N., \& Baka, H.O. (2015). The relationship between energy consumption, $\mathrm{CO} 2$ emissions and economic growth in Tanzania. Advances in Culture, Tourism and Hospitality Research, 7, 1-14. https://doi.org/10.1108/S1871-3173(2013)0000007004 
Alege, P.O., \& Ogundipe, A.A. (2013). Environmental quality and economic growth in Nigeria: A fractional cointegration analysis. International Journal of Development and Sustainability, 22(22), 580-596. Retrieved from www.isdsnet.com

Alkhathlan, K., Alam, M.Q., \& Javid, M. (2012). Carbon Dioxide Emissions, Energy Consumption and Economic Growth in Saudi Arabia: A Multivariate Cointegration Analysis. British Journal of Economics, Management \& Trade British Journal of Economics Management \& Trade, 2(4), 327-339. Retrieved from www.sciencedomain.org

Amin, S.B., Ferdaus, S.S., \& Porna, A.K. (2012). Causal Relationship among Energy Use, CO2 Emissions and Economic Growth in Bangladesh: An Empirical Study. World Journal of Social Sciences, 2(4), 273-290.

Amri, F. (2017). Carbon dioxide emissions, output, and energy consumption categories in Algeria. Environmental Science and Pollution Research, 24(17), 14567-14578. https://doi.org/10.1007/s11356-017-8984-7

Anastacio, J.A.R. (2017). Economic Growth, CO2 Emissions and Electric Consumption: Is there an Environmental Kuznets Curve? An Empirical Study for North America Countries. International Journal of Energy Economics and Policy, 7. Retrieved from http://www.econjournals.com/index.php/ijeep/article/view/4068

Ang, J.B. (2007). CO2 emissions, energy consumption, and output in France. Energy Policy, 35(10), 4772-4778. https://doi.org/10.1016/j.enpol.2007.03.032

Apergis, N., \& Ozturk, I. (2015). Testing environmental Kuznets curve hypothesis in Asian countries Ecological Indicators, 52, 16-22. https://doi.org/10.1016/j.ecolind.2014.11.026

Apergis, N., \& Payne, J.E. (2009). CO2 emissions, energy usage, and output in Central America. Energy Policy, 37(8), 3282-3286. https://doi.org/10.1016/j.enpol.2009.03.048

Arouri, M.E.H., Ben Youssef, A., M'henni, H., \& Rault, C. (2012). Energy consumption, economic growth and CO2 emissions in Middle East and North African countries. Energy Policy, 45, 342349. https://doi.org/10.1016/j.enpol.2012.02.042

Asongu, S.A., Montasser, G.E., \& Toumi, H. (2015). www.econstor.eu. AGDI Working Paper.

Balibey, M. (2015). Relationships Among Co2 Emissions, Economic Growth and Foreign Direct Investment and the Ekc Hypothesis in Turkey. International Journal of Energy Economics and Policy, 5(4), 1042-1049.

Ben Mbarek, M., Ben Ali, N., \& Feki, R. (2014). Causality relationship between CO2 emissions, GDP and energy intensity in Tunisia. Environment, Development and Sustainability, 16(6), 1253-1262. https://doi.org/10.1007/s10668-014-9525-x

Bese, E., \& Friday, H.S. (2021). The Effect of External Debt on Life Expectancy Through Foreign Direct Investment: Evidence from Turkey. Int. J. Econ. Financ., 11, 1-11.

Beşe, E., Friday, H.S., \& Özden, C. (2020). Coal Consumption Environmental Kuznets Curve (EKC) in China and Australia: Evidence From ARDL Model. J. Appl. Bus. Econ., 22, 25-36.

Bese, E., \& Friday, H.S. (2021). THE EFFECT OF THE KYOTO PROTOCOL. Aust. J. Bus. Manag. Res., pp. 1-31.

Beşe, E., Friday, H.S., \& Ozden, C. (2021a). The Effect of External Debt on Emissions: Evidence from China. Int. J. Energy Econ. Policy, 11, 440-447.

Beşe, E., Friday, H.S., \& Spencer, M. (2021b). Analysis of the Relationship Between Income Growth and Coal Consumption and Emissions From Nonlinear Perspective. J. Acad. Bus. Econ., 21, 52-72.

Beşe, E., \& Kalayci, S. (2019a). Testing the Environmental Kuznets Curve Hypothesis: Evidence from Egypt, Kenya and Turkey. Int. J. Energy Econ. Policy, 9, 479-491.

Beşe, E., \& Kalayci, S. (2019b). Environmental Kuznets Curve (EKC): Empirical Relationship Between Economic Growth, Energy Consumption, and CO2 Emissions: Evidence from 3 Developed Countries. Panoeconomicus, pp. 1-26.

Boopen, S., \& Vinesh, S. (2011). On the Relationship between Co2 Emissions and Economic Growth: The Mauritian Experience. British Journal of Economics, Management \& Trade, 2(4), 327-339. https://doi.org/10.1016/j.energy.2010.09.041 
Can, M., \& Gozgor, G. (2016). Dynamic Relationships Among CO2 Emissions, Energy Consumption, Economic Growth, and Economic Complexity in France. SSRN Electronic Journal, pp. 1-21. https://doi.org/10.2139/ssrn.2756638

Chai, J., Du, M., Liang, T., Christine, X., Yu, J., \& George, Z. (2019). Coal consumption in China: How to bend down the curve? Energy Economics, 80, 38-47.

https://doi.org/10.1016/j.eneco.2018.12.016

Chebbi, H.E., \& Boujelbene, Y. (2008, August 26-29, 2008). CO2 emissions, energy consumption and economic growth in Tunisia. 2008 International Congress, Ghent, Belgium, pp. 1-5. Retrieved from http://ageconsearch.umn.edu/bitstream/44016/2/367.pdf

Chen, J-H., \& Huang, Y-F. (2013). The Study of the Relationship between Carbon Dioxide (CO2) Emission and Economic Growth. Journal of International and Global Economic Studies, 6(2), 45-61. Retrieved from http://www2. southeastern.edu/orgs/econjournal/index_files/JIGES DEC 2013 CHEN HUANG 3-28-2014.pdf

Chontanawat, J., Hunt, L.C., \& Pierse, R. (2008). Does energy consumption cause economic growth?: Evidence from a systematic study of over 100 countries. Journal of Policy Modeling, 30(2), 209220. https://doi.org/10.1016/j.jpolmod.2006.10.003

Cohen, G., Tovar, J., Loungani, P., Marto, R., \& Wang, G. (2019). Decoupling of emissions and GDP: Evidence from aggregate and provincial Chinese data. Energy Economics, 77, 105-118. https://doi.org/10.1016/j.eneco.2018.03.030

Destek, M.A., Balli, E., \& Manga, M. (2016). The Relationship between CO2 Emission, Energy Consumption, Urbanization and Trade Openness for Selected CEECs. Research in World Economy, 7(1). https://doi.org/10.5430/rwe.v7n1p52

Dinda, S., \& Coondoo, D. (2006). Income and emission: A panel data-based cointegration analysis. Ecological Economics, 57(2), 167-181. https://doi.org/10.1016/j.ecolecon.2005.03.028

Dogan, E., \& Turkekul, B. (2016). CO2 emissions, real output, energy consumption, trade, urbanization and financial development: Testing the EKC hypothesis for the USA. Environmental Science and Pollution Research, 23(2), 1203-1213. https://doi.org/10.1007/s11356-015-5323-8

Dong, K., Sun, R., Jiang, H., \& Zeng, X. (2018). CO2 emissions, economic growth, and the environmental Kuznets curve in China: What roles can nuclear energy and renewable energy play? Journal of Cleaner Production, 196, 51-63. https://doi.org/10.1016/j.jclepro.2018.05.271

Du, G., Liu, S., Lei, N., \& Huang, Y. (2018). A test of environmental Kuznets curve for haze pollution in China: Evidence from the penal data of 27 capital cities. Journal of Cleaner Production, 205, 821-827. https://doi.org/10.1016/j.jclepro.2018.08.330

Esso, L. J., \& Keho, Y. (2016). Energy consumption, economic growth and carbon emissions: Cointegration and causality evidence from selected African countries. Energy, 114, 492-497. https://doi.org/10.1016/j.energy.2016.08.010

Fang, D., Hao, P., Wang, Z., \& Hao, J. (2019). Analysis of the Influence Mechanism of CO2 Emissions and Verification of the Environmental Kuznets Curve in China. International Journal of Environmental Research and Public Health, 16, 1-17. https://doi.org/10.3390/ijerph16060944

Farhani, S., \& Ozturk, I. (2015). Causal relationship between CO2 emissions, real GDP, energy consumption, financial development, trade openness, and urbanization in Tunisia. Environmental Science and Pollution Research, 22(20), 15663-15676. https://doi.org/10.1007/s11356-015-47671

Farhani, S., \& Rejeb, J.B. (2012). Energy consumption, economic growth and CO2 emissions: Evidence from panel data for MENA region. International Journal of Energy Economics and Policy, 2(2), 71-81. Retrieved from http://www.econjournals.com/index.php/ijeep/article/view/172

Fodha, M., \& Zaghdoud, O. (2010). Economic growth and pollutant emissions in Tunisia: An empirical analysis of the environmental Kuznets curve. Energy Policy, 38(2), 1150-1156. https://doi.org/10.1016/j.enpol.2009.11.002

Friedl, B., \& Getzner, M. (2002). Environment and growth in a small open economy: An EKC case-study for Austrian CO2 emissions. 
Gao, J., \& Zhang, L. (2014). Electricity consumption - economic growth - CO2 emissions nexus in Sub Saharan Africa: Evidence from panel cointegration. African Development Review, 26(2), 359371.

Ghosh, B.C., Alam, K.J., \& Osmani, A.G. (2014). Economic Growth, CO2 Emissions and Energy Consumption: The Case of Bangladesh. International Journal of Business and Economics Research, 3(6), 220. https://doi.org/10.11648/j.ijber.20140306.13

Gmidene, S., Zaidi, S., \& Zouari Ghorbel, S. (2016). Comparative analysis of energy consumption, CO2 emissions and economic growth: Evidence for OECD selected countries. International Journal of Accounting and Economics Studies, 4(2), 114. https://doi.org/10.14419/ijaes.v4i2.6378

Grossman, G.M., \& Krueger, A.B. (1991). Environmental Impacts of a North American Free Trade Agreement. National Bureau of Economic Research Working Paper Series, 3914(3914), 1-57. https://doi.org/10.3386/w3914

Gui, S., Zhao, L., \& Zhang, Z. (2019). Does municipal solid waste generation in China support the Environmental Kuznets Curve? New evidence from spatial linkage analysis. Waste Management, 84, 310-319. https://doi.org/10.1016/j.wasman.2018.12.006

Güriş, B. (2016). CO2 emissions and energy consumption in the US: Results from a threshold error correction model. Energy Sources, Part B: Economics, Planning and Policy, 11(4), 314-320. https://doi.org/10.1080/15567249.2011.618486

Hao, Y., Huang, Z., \& Wu, H. (2019). Do Carbon Emissions and Economic Growth Decouple in China? An Empirical Analysis Based on Provincial Panel Data. Energies, 12, 1-16.

Hao, Y., Wu, Y., Wang, L., \& Huang, J. (2018). Re-examine environmental Kuznets curve in China: Spatial estimations using environmental quality index. Sustainable Cities and Society, 42, 498511. https://doi.org/10.1016/j.scs.2018.08.014

He, Y., \& Lin, B. (2019). Investigating environmental Kuznets curve from an energy intensity perspective: Empirical evidence from China. Journal of Cleaner Production, 234, 1013-1022. https://doi.org/10.1016/j.jclepro.2019.06.121

Hussain, M., Javaid, M.I., \& Drake, P.R. (2012). An econometric study of carbon dioxide (CO2) emissions, energy consumption, and economic growth of Pakistan. Advances in Culture, Tourism and Hospitality Research, 7, 1-14. https://doi.org/10.1108/S1871-3173(2013)0000007004

Islam, N., Vincent, J., \& Panayotou, T. (1999). Unveiling the Income-Environment relationship: An exploration into the determinants of environment quality. Harvard Institute for International Development Development Discussion Paper No 701, 44.

Iwata, H., Okada, K., \& Samreth, S. (2012). Empirical study on the determinants of CO2 emissions: Evidence from OECD countries. Applied Economics, 44(27), 3513-3519. https://doi.org/10.1080/00036846.2011.577023

Jalil, A., \& Mahmud, S.F. (2009). Environment Kuznets curve for CO2 emissions: A cointegration analysis for China. Energy Policy, 37(12), 5167-5172. https://doi.org/10.1016/j.enpol.2009.07.044

Kacprzyk, A., \& Kuchta, Z. (2020). Shining a new light on the environmental Kuznets curve for CO2 emissions. Energy Economics. https://doi.org/10.1016/j.eneco.2020.104704

Kasman, A., \& Duman, Y.S. (2015). CO2 emissions, economic growth, energy consumption, trade and urbanization in new EU member and candidate countries: A panel data analysis. Economic Modelling, 44, 97-103. https://doi.org/10.1016/j.econmod.2014.10.022

Katırcioglu, S. (2017). Investigating the Role of Oil Prices in the Conventional EKC Model: Evidence from Turkey. Asian Economic and Financial Review, 7(5), 498-508. https://doi.org/10.18488/journal.aefr/2017.7.5/102.5.498.508

Kim, S. (2015). CO2 Emissions, Energy Consumption, GDP, and Foreign Direct Investment in ANICS Countries (pp. 1-22).

Kuo, K.C., Kanyasathaporn, P., \& Lai, S. (2014). The Causal Relationship between GDP, Energy Consumption and CO2 Emissions in Hong Kong (1, 127-138). https://doi.org/10.6148/IJITAS.2014.0701.05 
Kuznets, S. (1955). Economic Growth and Income Inequality. The American Economic Review, 45(1), 292-302. https://doi.org/10.1596/978-0-8213-7318-7

Latıfa, L., Yang, K.J., \& Xu, R.R. (2014, December). Economic growth and CO2 emissions in Malaysia: A cointegration analysis of the Environmental Kuznets Curve. ScienceDirect, 4, 1-14. https://doi.org/10.1016/j.enpol.2012.08.065

Lee, J.W., \& Brahmasrene, T. (2014). ICT, CO2 Emissions and Economic Growth: Evidence from a Panel of ASEAN. Global Economic Review, 43(2), 93-109. https://doi.org/10.1080/1226508X.2014.917803

Liang, W., \& Yang, M. (2019). Sustainable Computing: Informatics and Systems Urbanization, economic growth and environmental pollution: Evidence from China. Sustainable Computing: Informatics and Systems, 21, 1-9. https://doi.org/10.1016/j.suscom.2018.11.007

Linh, D.H., \& Lin, S. (2015). Dynamic Causal Relationships among CO2 Emissions, Energy Consumption, Economic Growth and FDI in the most Populous Asian Countries. Advances in Management \& Applied Economics, 5(1), 69-88. Retrieved from http://search.proquest.com/docview/1641639833/fulltextPDF/2B6546B5EFC440DFPQ/2?accoun tid $=28547$

Liu, J., Qu, J., \& Zhao, K. (2019). Is China's development conforms to the Environmental Kuznets Curve hypothesis and the pollution haven hypothesis? Journal of Cleaner Production, 234, 787 796. https://doi.org/10.1016/j.jclepro.2019.06.234

Liu, K., \& Lin, B. (2019). Research on in fl uencing factors of environmental pollution in China: A spatial econometric analysis. Journal of Cleaner Production, 206, 356-364. https://doi.org/10.1016/j.jclepro.2018.09.194

Liu, Y., Yan, B., \& Zhou, Y. (2016). Urbanization, economic growth, and carbon dioxide emissions in China: A panel cointegration and causality analysis. Journal of Geographical Sciences, 26(2), 131-152. https://doi.org/10.1007/s11442-016-1259-2

Lotfalipour, M.R., Falahi, M.A., \& Ashena, M. (2010). Economic growth, CO2 emissions, and fossil fuels consumption in Iran. Energy, 35(12), 5115-5120. https://doi.org/10.1016/j.energy.2010.08.004

Ma, M., Ma, X., Cai, W., \& Cai, W. (2020). Low carbon roadmap of residential building sector in China: Historical mitigation and prospective peak. Applied Energy, 273. https://doi.org/10.1016/j.apenergy.2020.115247

Magazzino, C. (2015). Economic growth, CO2 emissions and energy use in Israel. International Journal of Sustainable Development \& World Ecology, 22(1), 1-9. https://doi.org/10.1080/13504509.2014.991365

Magazzino, C. (2016a). Economic Growth, CO2 Emissions and Energy Use in the South Caucasus and Turkey: A PVAR analyses. International Energy Journal, 16, 153-162.

Magazzino, C. (2016b). The relationship between real GDP, CO2 emissions, and energy use in the GCC countries: A time series approach. Cogent Economics \& Finance, 4(1), 1152729. https://doi.org/10.1080/23322039.2016.1152729

Mallick, L., \& Tandi, S.M. (2015). Energy consumption, economic growth, and CO2 emissions in SAARC countries: Does environmental Kuznets curve exist? The Empirical Econometrics and Quantitative Economics Letters, 44(33), 57-69. Retrieved from http://www.jyoungeconomist.com/images/stories/EEQEL_v4n3_06_.pdf

Martinez-Zarzoso, I., \& Bengochea-Morancho, A. (2003). Testing for an environmental Kuznets curve in latin-american countries. Revista de Análisis Económico, 18(1), 3-26.

Mele, M., \& Randazzo, L. (2019). A causal investigation on the determinants of CO2 in China. International Journal of Sustainable Development \& World Ecology, 26(8), 665-671. https://doi.org/10.1080/13504509.2019.1641567

Mercan, M., \& Karakaya, E. (2014, October). Energy Consumption, Economic Growth and Carbon Emission: Dynamic Panel Cointegration Analysis for Selected OECD Countries. Procedia Economics and Finance, 23, 587-592. https://doi.org/10.1016/S2212-5671(15)00572-9 
Mitić, P., Munitlak Ivanović, O., \& Zdravković, A. (2017). A Cointegration Analysis of Real GDP and CO2 Emissions in Transitional Countries. Sustainability, 9(4), 568. https://doi.org/10.3390/su9040568

Mrabet, A., Achairi, R., \& Ellouze, A. (2014). The Two-Way relationship between Economic Growth and $\mathrm{CO} 2$ Emissions. International Conference on Business, Economics, Marketing \& Management Research, 2, 32-35.

Munir, S., \& Khan, A. (2014). Impact of Fossil Fuel Energy Consumption on CO2 Emissions: Evidence from Pakistan (1980-2010). The Pakistan Development Review, 53(4), 327-346.

Musolesi, A., Mazzanti, M., \& Zoboli, R. (2010). A panel data heterogeneous Bayesian estimation of environmental Kuznets curves for CO2 emissions. Applied Economics, 42(18), 2275-2287. https://doi.org/10.1080/00036840701858034

Nain, M.Z., Ahmad, W., \& Kamaiah, B. (2017). Economic growth, energy consumption and CO2 emissions in India: A disaggregated causal analysis. International Journal of Sustainable Energy, 36(8), 807-824. https://doi.org/10.1080/14786451.2015.1109512

Nie, Y., Li, Q., Wang, E., \& Zhang, T. (2019). Study of the nonlinear relations between economic growth and carbon dioxide emissions in the Eastern, Central and Western regions of China. Journal of Cleaner Production, 219, 713-722. https://doi.org/10.1016/j.jclepro.2019.01.164

Osabuohien, E.S., Efobi, U.R., \& Gitau, C.M.W. (2014). Beyond the Environmental Kuznets Curve in Africa: Evidence from Panel Cointegration. Journal of Environmental Policy \& Planning, 16(4), 517-538. https://doi.org/10.1080/1523908X.2013.867802

Ozcan, B. (2013). The nexus between carbon emissions, energy consumption and economic growth in Middle East countries: A panel data analysis. Energy Policy, 62, 1138-1147. https://doi.org/10.1016/j.enpol.2013.07.016

Özden, C., Beşe, E. (2021). Environmental Kuznets Curve (EKC) in Australia: Evidence from Nonlinear ARDL Model with a Structural Break. Polish J. Environ. Stud., 30, 1-11. https://doi.org/10.15244/pjoes/127555

Ozturk, I., \& Acaravci, A. (2016). Energy consumption, CO2 emissions, economic growth, and foreign trade relationship in Cyprus and Malta. Energy Sources, Part B: Economics, Planning and Policy, 11(4), 321-327. https://doi.org/10.1080/15567249.2011.617353

Ozturk, Z., \& Oz, D. (2016, June). The Relationship between Energy Consumption, Income, Foreign Direct Investment, and CO2 Emissions: The Case of Turkey (pp. 0-20).

Palamalai, S., Siddanth, I., \& Prakasam, K. (2015). Relationship between Energy Consumption, CO2 Emissions, Economic Growth and Trade in India [01(02), 1-17].

Panayotou, T. (1993). Empirical tests and policy analysis of environmental degradation at different stages of economic development. International Labour Office. https://doi.org/http://scihub.tw/http://www.ilo.org/public/libdoc/ilo/1993/93B09_31_engl.pdf

Pandey, S. (2016). An Econometric Analysis of The Relationships Between CO2 Emissions, Economic Growth, Imports and Service Sector of India. South-Asian Journal of Multidisciplinary Studies, pp. 128-149.

Pao, H.T., \& Tsai, C.M. (2011). Multivariate Granger causality between CO2 emissions, energy consumption, FDI (foreign direct investment) and GDP (gross domestic product): Evidence from a panel of BRIC (Brazil, Russian Federation, India, and China) countries. Energy, 36(1), 685693. https://doi.org/10.1016/j.energy.2010.09.041

Pilatowska, M., Wlodarczyk, A., \& Zawada, M. (2015). CO2 emissions, energy consumption and economic growth in the EU countries: Evidence from threshold cointegration analysis. 2015 12th International Conference on the European Energy Market (EEM), pp. 1-5. https://doi.org/10.1109/EEM.2015.7216646

Pincheira, R., \& Zuniga, F. (2020). Environmental Kuznets curve bibliographic map: A systematic literature review. Accounting and Finance. https://doi.org/10.1111/acfi.12648 
Purcel, A.A. (2020). New insights into the environmental Kuznets curve hypothesis in developing and transition economies: A literature survey. Environmental Economics and Policy Studies, 22. Springer Japan. https://doi.org/10.1007/s10018-020-00272-9

Saboori, B, \& Soleymani, A. (2011). CO2 emissions, economic growth and energy consumption in Iran: A co- integration approach. International Journal of Environmental Sciences, 2(1), 44-53.

Saboori, B., Sulaiman, J., \& Mohd, S. (2012b). Economic growth and CO2 emissions in Malaysia: A cointegration analysis of the Environmental Kuznets Curve. Energy Policy, 51, 184-191. https://doi.org/10.1016/j.enpol.2012.08.065

Saboori, B., Sulaiman, J., \& Mohd, S. (2016). Environmental Kuznets curve and energy consumption in Malaysia: A cointegration approach. Energy Sources, Part B: Economics, Planning and Policy, 11(9), 861-867. https://doi.org/10.1080/15567249.2012.662264

Saboori, B., Sulaiman, J.B., \& Mohd, S. (2012a). An Empirical Analysis of the Environmental Kuznets Curve for $\mathrm{CO} 2$ Emissions in Indonesia: The Role of Energy Consumption and Foreign Trade. International Journal of Economics and Finance, 4(2), 243-251. https://doi.org/10.5539/ijef.v4n2p243

Saleh, I., Abedi, S., \& Abedi, S. (2014). A Panel Data Approach for Investigation of Gross Domestic Product (GDP) and CO2 Causality Relationship (16, 947-956).

Sarkodie, S.A., \& Strezov, V. (2018). Empirical study of the Environmental Kuznets curve and Environmental Sustainability curve hypothesis for Australia, China, Ghana and USA. Journal of Cleaner Production, 201, 98-110. https://doi.org/10.1016/j.jclepro.2018.08.039

Sarkodie, S.A., Adams, S., Owusu, P.A., Leirvik, T., \& Ozturk, I. (2020). Science of the Total Environment Mitigating degradation and emissions in China: The role of environ- mental sustainability, human capital and renewable energy. Science of the Total Environment, 719, 137530. https://doi.org/10.1016/j.scitotenv.2020.137530

Shafik, N., \& Bandyopadhyay, S. (1992). Economic growth and environmental quality: Time series and cross-country evidence. Policy Research Working Paper Series, 18(5), 55. https://doi.org/10.1108/14777830710778328

Shahbaz, M., \& Sinha, A. (2019). Environmental Kuznets curve for CO2 emissions: A literature survey. Journal of Economic Studies, 46(1), 106-168. https://doi.org/10.1108/JES-09-2017-0249

Shahbaz, M., Dube, S., Ozturk, I., \& Jalil, A. (2015). Testing the Environmental Kuznets Curve Hypothesis in Portugal. International Journal of Energy Economics and Policy, 5(2), 475-481.

Shahbaz, M., Jam, F.A., Bibi, S., \& Loganathan, N. (2016). Multivariate Granger causality between CO2 emissions, energy intensity and economic growth in Portugal: Evidence from cointegration and causality analysis. Technological and Economic Development of Economy, 22(1), 47-74. https://doi.org/10.3846/20294913.2014.989932

Shahbaz, M., Lean, H.H., \& Shabbir, M.S. (2012). Environmental Kuznets Curve hypothesis in Pakistan: Cointegration and Granger causality. Renewable and Sustainable Energy Reviews, 16(5), 29472953. https://doi.org/10.1016/j.rser.2012.02.015

Shahbaz, M., Mahalik, M.K., Shah, S.H., \& Sato, J.R. (2016). Time-varying analysis of CO2 emissions, energy consumption, and economic growth nexus: Statistical experience in next 11 countries. Energy Policy, 98, 33-48. https://doi.org/10.1016/j.enpol.2016.08.011

Song, T., Zheng, T., \& Tong, L. (2008). An empirical test of the environmental Kuznets curve in China: A panel cointegration approach. China Economic Review, 19(3), 381-392. https://doi.org/10.1016/j.chieco.2007.10.001

Song, Y., Zhang, M., \& Zhou, M. (2019). Study on the decoupling relationship between CO2 emissions and economic development based on two-dimensional decoupling theory: A case between China and the United States. Ecological Indicators, 102, 230-236. https://doi.org/10.1016/j.ecolind.2019.02.044

Tan, C. (2019). Environmental Kuznets Curve of Household Electricity Consumption in China: Based on Spatial Econometric Model. Journal of Energy Research and Reviews, 2(3), 1-12. https://doi.org/10.9734/JENRR/2019/v2i330080 
Tang, C.T., \& Tan, P.P. (2016). Carbon Dioxıde Emıssions, Energy Consumption, And Economıc Growth In A Transition Economy: Empirical Evidence From Cambodia. Labuan Bulletin of International Business \& Finance, 14.

Temurshoev, U. (2006). Pollution Haven Hypothesis or Factor Endowment Hypothesis: Theory and Empirical Examination for the US and China. SSRN Electronic Journal. https://doi.org/10.2139/ssrn. 1147660

Tiwari, A.K. (2011). Energy consumption, CO2 emissions and economic growth: Evidence from India. Journal of International Business and Economy, 12(1), 85-122.

Uçak, H., Aslan, A., Yucel, F., \& Turgut, A. (2015). A Dynamic Analysis of CO2 Emissions and the GDP Relationship: Empirical Evidence from High-income OECD Countries. Energy Sources, Part B: Economics, Planning, and Policy, 10(1), 38-50. https://doi.org/10.1080/15567249.2010.514586

Uddin, M.G.S., Bidisha, S.H., \& Ozturk, I. (2016). Carbon emissions, energy consumption, and economic growth relationship in Sri Lanka. Energy Sources, Part B: Economics, Planning and Policy, 11(3), 282-287. https://doi.org/10.1080/15567249.2012.694577

Wang, K-M. (2012). Modelling the nonlinear relationship between CO2 emissions from oil and economic growth. Economic Modelling, 29(5), 1537-1547. https://doi.org/10.1016/J.ECONMOD.2012.05.001

Wang, S., Fang, C., Guan, X., Pang, B., \& Ma, H. (2014). Urbanisation, energy consumption, and carbon dioxide emissions in China: A panel data analysis of China's provinces. Applied Energy, 136, 738-749. https://doi.org/10.1016/j.apenergy.2014.09.059

Wang, S.S., Zhou, D.Q., Zhou, P., \& Wang, Q.W. (2011). CO2 emissions, energy consumption and economic growth in China: A panel data analysis. Energy Policy, 39(9), 4870-4875. https://doi.org/10.1016/j.enpol.2011.06.032

Wang, Y., \& He, X. (2019). Spatial economic dependency in the Environmental Kuznets Curve of carbon dioxide: The case of China. Journal of Cleaner Production, 218, 498-510. https://doi.org/10.1016/j.jclepro.2019.01.318

Xie, Q., Xu, X., \& Liu, X. (2019). Is there an EKC between economic growth and smog pollution in China? New evidence from semiparametric spatial autoregressive models. Journal of Cleaner Production, 220, 873-883. https://doi.org/10.1016/j.jclepro.2019.02.166

Yao, S., Zhang, S., \& Zhang, X. (2019). Renewable energy, carbon emission and economic growth: A revised environmental Kuznets Curve perspective*. Journal of Cleaner Production, 235, 13381352. https://doi.org/10.1016/j.jclepro.2019.07.069

Yavuz, N.Ç. (2014). CO2 Emission, energy consumption, and economic growth for Turkey: Evidence from a cointegration test with a structural break. Energy Sources, Part B: Economics, Planning and Policy, 9(3), 229-235. https://doi.org/10.1080/15567249.2011.567222

Yazdi, S.K., \& Mastorakis, N. (2016, September). The Dynamic Links between Economic Growth, Energy Intensity and CO2 Emissions in Iran (pp. 140-146).

Zhang, W., Sharp, B., \& Xu, S. (2019). Does economic growth and energy consumption drive environmental degradation in China's 31 provinces? New evidence from a spatial econometric perspective. Applied Economics, 51(42), 4658-4671. https://doi.org/10.1080/00036846.2019.1593943

Zhou, C., Wang, S., \& Wang, J. (2019). Examining the influences of urbanization on carbon dioxide emissions in the Yangtze River Delta, China: Kuznets curve relationship. Science of the Total Environment, 675, 472-482. https://doi.org/10.1016/j.scitotenv.2019.04.269

Zoundi, Z. (2017, July). CO2 emissions, renewable energy and the Environmental Kuznets Curve, a panel cointegration approach. Renewable and Sustainable Energy Reviews, 72, 1067-1075. https://doi.org/10.1016/j.rser.2016.10.018 